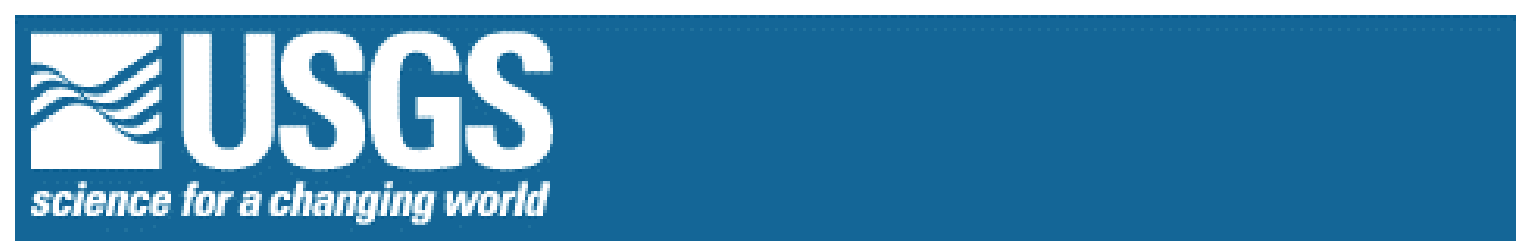

U.S. DEPARTMENT OF THE INTERIOR

U.S. GEOLOGICAL SURVEY

\title{
STATISTICAL TABLES AND CHARTS SHOWING GEOCHEMICAL VARIATION IN THE MESOPROTEROZOIC BIG CREEK, APPLE CREEK, AND GUNSIGHT FORMATIONS, LEMHI GROUP, SALMON RIVER MOUNTAINS AND LEMHI RANGE, CENTRAL IDAHO
}

By David A. Lindsey, Russell G. Tysdal, and Joseph E. Taggart, Jr.

OPEN-FILE REPORT 02-310

This report is preliminary and has not been reviewed for conformity with U. S. Geological Survey editorial standards or with the North American Stratigraphic Code. Any use of trade, product, or firm names is for descriptive purposes only and does not imply endorsement by the U. S. Government.

${ }^{1}$ U. S. Geological Survey, Denver, Colo., 80225 


\section{Table of contents}

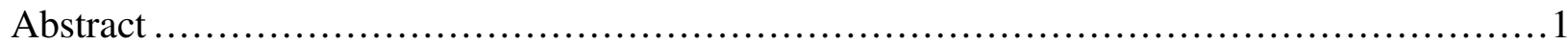

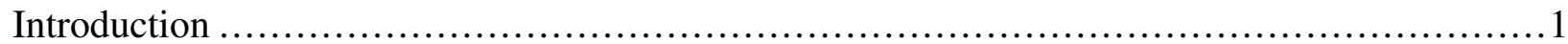

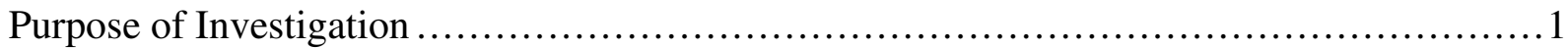

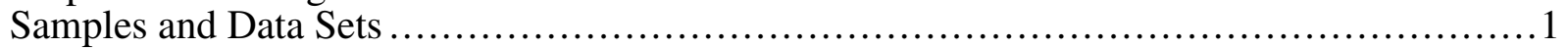

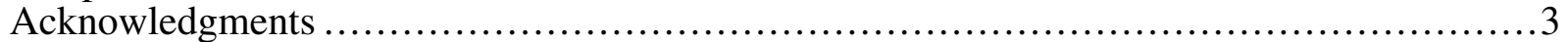

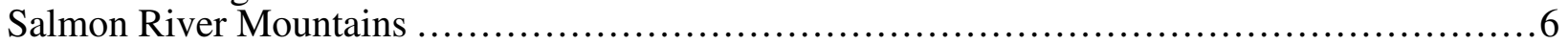

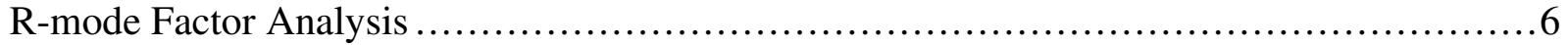

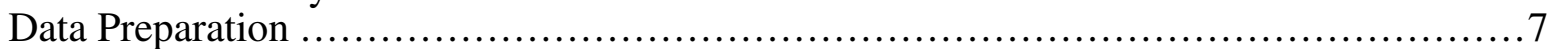

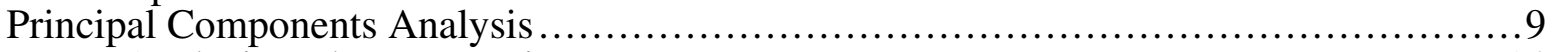

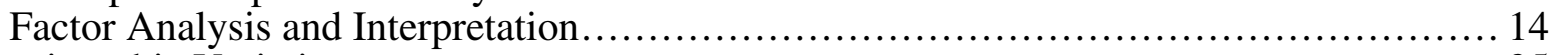

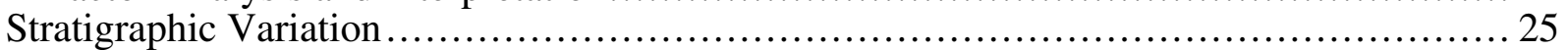

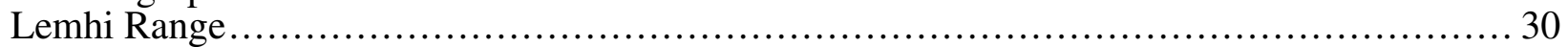

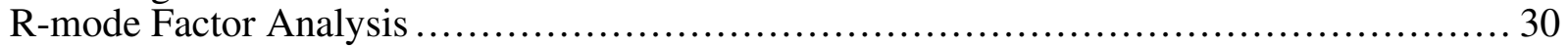

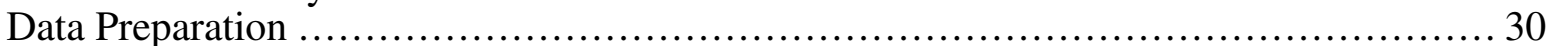

Principal Components Analysis ....................................................... 33

Factor Analysis and Interpretation.................................................. 35

Stratigraphic Variation ............................................................ 42

Comparison of Rock Compositions: Salmon River Mountains versus the Lemhi Range........ 49

Classification by Major-oxide Ratios .................................................... 51

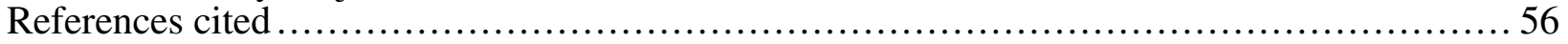

Appendix Tables $1-2$................................................................. 59

Appendix--Factor analysis of log-ratio data, Salmon River Mountains....................... 62 


\section{List of Figures}

Figure 1.--Index map showing generalized location of samples for geochemical data sets for metasedimentary rocks of the Mesoproterozoic Lemhi Group, Salmon River Mountains and Lemhi Range, central Idaho.

Figure 2.--Eigenvalues compared to broken-stick distribution, showing possible choices for number of components to select for rotation, Apple Creek and Gunsight Formations, Salmon River Mountains.

Figure 3.--Scattergrams of selected factor 1 oxides and elements in the Apple Creek and Gunsight Formations, Salmon River Mountains: A) $\mathrm{Al}_{2} \mathrm{O}_{3}$ versus $\mathrm{TiO}_{2}$, B) Sc versus $\mathrm{TiO}_{2}$, C) Sc versus $\mathrm{Cr}$, and D) Sc versus V.

Figure 4.--Scattergrams of factor 4 oxides, elements, and plagioclase, Apple Creek and Gunsight Formations, Salmon River Mountains: A) $\log \mathrm{CaO}$ versus $\left.\mathrm{Na}_{2} \mathrm{O}, \mathrm{B}\right) \log \mathrm{CaO}$ and $\mathrm{Na}_{2} \mathrm{O}$ versus plagioclase, C) $\log \mathrm{CaO}$ versus $\log \mathrm{Sr}$, and D) $\mathrm{Na}_{2} \mathrm{O}$ versus $\log \mathrm{Sr}$.

Figure 5.--Scattergrams illustrating mixtures of quartz $\left(\mathrm{SiO}_{2}\right)$, muscovite, biotite, alkali feldspar, and plagioclase to produce sandstone, siltite, and argillite of the Apple Creek and Gunsight Formations, Salmon River Mountains: A) $\mathrm{Al}_{2} \mathrm{O}_{3}$ versus $\mathrm{SiO}_{2}$, B) $\mathrm{K}_{2} \mathrm{O}$ versus $\mathrm{SiO}_{2}$, and C) $\mathrm{Al}_{2} \mathrm{O}_{3}$ versus $\mathrm{K}_{2} \mathrm{O}$.

Figure 6.--Scattergrams of factor 2 trace elements and other selected oxides in the Apple Creek and Gunsight Formations, Salmon River Mountains: A) Ce versus La, B) Ce versus Nd, C) $\mathrm{Nd}$ versus $\mathrm{La}, \mathrm{D}) \mathrm{Ce}$ versus $\mathrm{P}_{2} \mathrm{O}_{5}$, and $\mathrm{E}$ ) $\mathrm{Nd}$ versus $\mathrm{TiO}_{2}$.

Figure 7.--Histograms showing frequency distributions of factor 3 elements $\mathrm{As}, \mathrm{Sb}, \mathrm{Mn}, \mathrm{Pb}$, and $\mathrm{Zn}$ in the Apple Creek and Gunsight Formations, Salmon River Mountains.

Figure 8.--Histograms comparing frequency distributions of cobalt and copper in the Apple Creek and Gunsight Formations, Salmon River Mountains, with the Ravalli Group, Belt basin, Montana.

Figure 9.--Interaction bar charts showing mean scores by formation and rock type, Apple Creek and Gunsight Formations, Salmon River Mountains.

Figure 10.--Scattergrams showing A) $\mathrm{CaO}$ versus $\mathrm{Na}_{2} \mathrm{O}$ and $\mathrm{B}$ ) $\mathrm{CaO}$ versus $\mathrm{Sr}$, for stratigraphic units of the Apple Creek and Gunsight Formations, Salmon River Mountains.

Figure 11.--Eigenvalues compared to broken-stick distribution, showing possible choices for number of components to select for rotation, Big Creek and Apple Creek Formations, Lemhi Range.

Figure 12.--Scattergrams of factor 1 oxides and trace elements in the Big Creek and Apple Creek Formations, Lemhi Range: A) $\mathrm{Al}_{2} \mathrm{O}_{3}$ versus $\mathrm{K}_{2} \mathrm{O}$, B) $\mathrm{Al}_{2} \mathrm{O}_{3}$ versus $\log \mathrm{TiO}_{2}, \mathrm{C}$ ) $\mathrm{Al}_{2} \mathrm{O}_{3}$ versus $\left.\log \mathrm{Ga}, \mathrm{D}\right) \log \mathrm{Ga}$ versus $\log \mathrm{TiO}_{2}$, and $\left.\mathrm{E}\right) \log \mathrm{Sc}$ versus $\log \mathrm{TiO}_{2}$.

Figure 13.--Scattergrams for factor 2 oxides $\left(\log \mathrm{CaO}\right.$ and $\log \mathrm{Na}_{2} \mathrm{O}$ ), Big Creek and Apple Creek Formations, Lemhi Range: A) classified by rock type, B) classified by stratigraphic unit.

Figure 14.--Scattergrams illustrating mixtures of quartz $\left(\mathrm{SiO}_{2}\right)$, muscovite, biotite, alkali feldspar and plagioclase to produce sandstone, siltite, argillite, and diamictite in the Big Creek and Apple Creek Formations, Lemhi Range. A) $\mathrm{Al}_{2} \mathrm{O}_{3}$ versus $\left.\mathrm{SiO}_{2}, \mathrm{~B}\right) \mathrm{K}_{2} \mathrm{O}$ versus $\mathrm{SiO}_{2}$, and C) $\mathrm{Al}_{2} \mathrm{O}_{3}$ versus $\mathrm{K}_{2} \mathrm{O}$.

Figure 15.--Scattergrams for factor 4 oxides and elements, and $\mathrm{TiO}_{2}$, Big Creek and Apple Creek Formations, Lemhi Range: A) $\log \mathrm{Fe}_{\mathrm{T}} \mathrm{O}_{3}$ (total iron as $\mathrm{Fe}_{2} \mathrm{O}_{3}$ ) versus $\log \mathrm{Ba}, \mathrm{B}$ ) $\log$ $\mathrm{Fe}_{\mathrm{T}} \mathrm{O}_{3}$ versus $\log \mathrm{TiO}_{2}$, and C) $\mathrm{Fe}_{\mathrm{T}} \mathrm{O}_{3}$ versus $\mathrm{TiO}_{2}$ for sandstone of the Big Creek formation.

Figure 16.--Frequency distributions for $\mathrm{A}$ ) $\mathrm{Co}$ and $\mathrm{B}$ ) $\mathrm{Cu}$ in the Big Creek and Apple Creek Formations, Lemhi Range.

Figure 17.--Box plots for composition of siltite, showing median and percentile $\left(10^{\text {th }}, 25^{\text {th }}, 75^{\text {th }}\right.$, and $90^{\text {th }}$ ) values, and outlying values for $\mathrm{CaO}, \mathrm{Na}_{2} \mathrm{O}, \mathrm{Fe}_{\mathrm{T}} \mathrm{O}_{3}$, and $\mathrm{Ba}$, Big Creek and Apple Creek Formations, Lemhi Range.

Figure 18.--Chemical classification of rocks in the Lemhi Group by $\log \mathrm{SiO}_{2} / \mathrm{Al}_{2} \mathrm{O}_{3}$ vs $\log$ $\mathrm{K}_{2} \mathrm{O} / \mathrm{Na}_{2} \mathrm{O}$ and $\log \left(\left(\mathrm{Fe}_{\mathrm{T}} \mathrm{O}_{3}+\mathrm{MgO}\right) /\left(\mathrm{Na}_{2} \mathrm{O}+\mathrm{K}_{2} \mathrm{O}\right)\right)$, Salmon River Mountains and Lemhi Range. 
Figure 19.--Classification of rocks in the Lemhi Group by $\log \mathrm{Fe}_{\mathrm{T}} \mathrm{O}_{3} / \mathrm{K}_{2} \mathrm{O}$ vs $\log \mathrm{SiO}_{2} / \mathrm{Al}_{2} \mathrm{O}_{3}$, Salmon River Mountains and Lemhi Range.

\section{List of Tables}

Table 1.--Samples of metasedimentary rocks of the Mesoproterozoic Lemhi Group classified by formation (including facies and units) and rock type, Salmon River Mountains and Lemhi Range, central Idaho.

Table 2.--Replacement values, lower limit of detection, and number of replaced values, Apple Creek and Gunsight Formations, Salmon River Mountains.

Table 3.--Descriptive statistics for major and trace elements, Apple Creek and Gunsight Formations, Salmon River Mountains.

Table 4.--Eigenvalues and proportion of variance, principal components analysis of 35X35 Rmatrix, Apple Creek and Gunsight Formations, Salmon River Mountains.

Table 5.--Communalities for 4- and 9-factor solutions, Apple Creek and Gunsight Formations, Salmon River Mountains.

Table 6.--Orthogonal axes, 4 factors (Varimax rotation), Apple Creek and Gunsight Formations, Salmon River Mountains.

Table 7.--Linear correlation coefficients for factor 3 elements, Apple Creek and Gunsight Formations, Salmon River Mountains.

Table 8.--Linear correlation coefficients between $\log \mathrm{Fe}_{\mathrm{T}} \mathrm{O}_{3}$ (total iron as $\mathrm{Fe}_{2} \mathrm{O}_{3}$ ), $\mathrm{TiO}_{2}, \log \mathrm{Ba}$, $\log \mathrm{Co}$, and $\log \mathrm{Mn}$, Apple Creek and Gunsight Formations, Salmon River Mountains.

Table 9.--Analysis of variance for factor 1-4 scores and for element values with high loadings on factor 4, for differences among rock types and stratigraphic units, Apple Creek and Gunsight Formations, Salmon River Mountains.

Table 10.--Replacement values, lower limit of detection, and number of replaced values, Big Creek and Apple Creek Formations, Lemhi Range, Idaho.

Table 11.--Descriptive statistics for major and trace elements, Big Creek and Apple Creek Formations, Lemhi Range, Idaho.

Table 12.--Eigenvalues and proportion of variance, principal components analysis of $25 \mathrm{X} 25 \mathrm{R}-$ matrix, Big Creek and Apple Creek Formations, Lemhi Range.

Table 13.--Communalities for 1-, 2-, 3-, 4-, and 7-factor solutions, Big Creek and Apple Creek Formations, Lemhi Range.

Table 14.--Orthogonal axes, 4 factors (Varimax rotation), Big Creek and Apple Creek Formations, Lemhi Range.

Table 15.--Linear correlation coefficients for factor 4 elements and $\log \mathrm{TiO}_{2}$, Big Creek and Apple Creek Formations, , Lemhi Range, Idaho.

Table 16.--Analysis of variance of factor scores for siltite, Big Creek and Apple Creek Formations, Lemhi Range.

Table 17.--Analysis of variance and Fisher's PLSD test for differences among mean values for factor 2 scores, $\log \mathrm{CaO}$, and $\log \mathrm{Na}_{2} \mathrm{O}$ in siltite, Big Creek and Apple Creek Formations, Lemhi Range.

Table 18.--Analysis of variance and Fisher's PLSD test for differences among mean values for factor 4 scores, $\log \mathrm{Fe}_{\mathrm{T}} \mathrm{O}_{3}$, and $\log \mathrm{Ba}$ in siltite, Big Creek and Apple Creek Formations, Lemhi Range.

Table 19.--Median values and results of Mann-Whitney U-test for major oxides in the coarse siltite unit (Yac) of the Apple Creek Formation, Salmon River Mountains and Lemhi Range, Idaho.

Appendix Table 1.--Correlation matrix (35X35) for 98 samples, Apple Creek and Gunsight Formations, Salmon River Mountains.

Appendix Table 2.--Correlation matrix (25X25) for 128 samples, Big Creek and Apple Creek Formations, Lemhi Range.

Appendix Table 3.--Matrix (20X20) of centered log-ratio correlation coefficients, ouput from program "pcaconst" (Reyment and Savazzi, 1999), Salmon River Mountains data set. 
Appendix Table 4.--Raw 20X20 R-matrix, crude equivalent of Appendix Table 3, calculated from untransformed data, Salmon River Mountains data set.

Appendix Table 5.--Comparison of eigenvalues, principal components analysis of $20 X 20$ matrix of centered log-ratio correlation coefficients versus raw correlation coefficients, Salmon River Mountains.

Appendix Table 6.--Comparison of communalities, 4-factor orthogonal solution, principal components analysis of 20X20 matrix of centered log-ratio correlation coefficients versus raw correlation coefficients, Salmon River Mountains.

Appendix Table 7.--Comparison of factor loadings and interpretations, 4-factor orthogonal solution (Varimax rotation), principal components analysis of 20X20 matrix of centered log-ratio correlation coefficients versus raw correlation coefficients, Salmon River Mountains.

Appendix Table 8.--Comparison of factor interpretations, A) 20X20 log-ratio R-matrix, B) 20X20 raw R-matrix, and C) 35X35 R-matrix used in original principal components analysis, Salmon River Mountains data set.

Appendix Table 9.--Correlations of row geometric means with raw compositional data, Salmon River Mountains data set 


\title{
STATISTICAL TABLES AND CHARTS SHOWING GEOCHEMICAL VARIATION IN THE MESOPROTEROZOIC BIG CREEK, APPLE CREEK, AND GUNSIGHT FORMATIONS, SALMON RIVER MOUNTAINS AND LEMHI RANGE, CENTRAL IDAHO
}

\author{
By David A. Lindsey, Russell G. Tysdal, and Joseph E. Taggart
}

\begin{abstract}
The principal purpose of this report is to provide a reference archive for results of a statistical analysis of geochemical data for metasedimentary rocks of Mesoproterozoic age of the Salmon River Mountains and Lemhi Range, central Idaho. Descriptions of geochemical data sets, statistical methods, rationale for interpretations, and references to the literature are provided.

Three methods of analysis are used: R-mode factor analysis of major oxide and trace element data for identifying petrochemical processes, analysis of variance for effects of rock type and stratigraphic position on chemical composition, and major-oxide ratio plots for comparison with the chemical composition of common clastic sedimentary rocks.

\section{INTRODUCTION \\ Purpose of Investigation}

Previous geochemical investigations of Mesoproterozoic metasedimentary rocks of the Salmon River Mountains were oriented toward understanding the nature and stratigraphic distribution of cobalt mineralization (Connor, 1990; 1991a; Nash, 1989). The present investigation is aimed at identifying sedimentary processes that affected the chemical composition of these rocks and correlative rocks in the Lemhi Range. Understanding the effects of sedimentation on chemical composition may assist in understanding the provenance and, ultimately, the correlation of Mesoproterozoic metasedimentary rocks in Idaho and Montana.
\end{abstract}

\section{Samples and Data Sets}

Two geochemical data sets were selected for this investigation (Fig. 1; Table 1). One data set, representing rocks in the Salmon River Mountains, was selected from analyses of samples collected by J.J. Connor (1990). These samples were formerly assigned to the Mesoproterozoic Yellowjacket Formation (Connor and Evans, 1986; Connor, 1990; Evans and Connor, 1993) but, for this study, they have been reassigned to the Apple Creek and Gunsight Formations (Table 1). A second data set, representing rocks in the northern Lemhi Range, was selected from analyses of samples collected by R.G. Tysdal, during study of the Lemhi Group (Tysdal, 1996a,1996b; Tysdal and Moye, 1996). The second data set also includes analyses of ten samples collected by J.J. Connor from the northern Lemhi Range (Connor, 1991a) (Fig. 1). The Lemhi Range data set represents rocks of the Big Creek and Apple Creek Formations (Table 1).

Both data sets represent unweathered rock samples. In the Salmon River Mountains, samples consisted of 250-500 g of rock chips collected across a stratigraphic interval of $5-15 \mathrm{~cm}$ (Connor, 1990). In the northern Lemhi Range, samples consisted of single rock specimens weighing approximately 200-300 g. Sample locations are distributed over most of the two study areas. Except in mineralized zones of the Salmon River Mountains, most samples were unmineralized in appearance.

The data sets were examined for evidence of the petrologic processes, including sedimentary processes, that formed the Mesoproterozoic rocks in central Idaho. Examination consisted of statistical analysis of covariation (R-mode factor analysis) among major oxides and trace elements and analysis of variance of the same data for stratigraphic variation. The statistical analyses were used to identify petrogenetic processes responsible for the chemical composition of Mesoproterozoic rocks.

The samples of Connor (1990) from the Salmon River Mountains were reassigned to formations of the Lemhi Group by R.G. Tysdal (2000a) (Table 1). Reassignment became necessary after R.G. Tysdal (Tysdal, 1996a,1996b; Tysdal and Moye, 1996) mapped the Lemhi 
Group in the northern part of the Lemhi Range and realized that the stratigraphic units there were equivalent to rocks in the Salmon River Mountains, formerly assigned to the Yellowjacket Formation. Samples from outlying areas, from the type Yellowjacket Formation, and from the Mesoproterozoic Hoodoo Quartzite, all of uncertain stratigraphic relation to the Lemhi Group, were excluded from the Salmon River Mountains data set. Also excluded were a few samples of unusual rock types, including banded iron formation, tourmalinite breccia, one sample of diamictite, and biotitite (biotite-rich schist). The resulting Salmon River Mountains sample set, used in this investigation, contained 98 samples of quartzite (metasandstone), siltite, and argillite. (Most metasandstones sampled in the Lemhi Group are feldspathic (Lopez, 1981)). The quartzrich Swauger Formation is not represented in the data sets. To emphasize grain size and not mineralogy, the rock names "sandstone" and "metasandstone" are used here to refer to metamorphic rocks called "quartzite" in previous reports).

For the purposes of this investigation, each data set has advantages and disadvantages. The data set from the Salmon River Mountains (Connor, 1990) contains analyses of major oxides and numerous trace elements, making it ideal for identification of petrogenetic factors affecting rock composition. Major oxides were analyzed by X-ray fluorescence spectrometry (Taggart and others, 1987). Most trace elements were analyzed by inductively coupled plasma-atomic absorption emission spectroscopy (Lichte and others, 1987), except thorium and uranium, which were determined by the delayed-neutron method (McKown and Millard, 1987). The data set also includes analyses of approximately equal numbers of metasedimentary rocks distinguishable by grain size: (meta)sandstone, siltite, and argillite. Samples in the data set are distributed approximately equally among three stratigraphic units (herein referenced generically as "formations"). Only siltite and argillite are under-represented in the Gunsight Formation. Thus, the Salmon River Mountains data set is amenable to analysis of both stratigraphic and grain-size effects on rock composition. Rocks of the Salmon River Mountains, however, are metamorphosed; biotite and muscovite of metamorphic origin are widespread and abundant. Any genetic interpretation of the sedimentary origin of rocks in the Salmon River Mountains must take into account possible effects of metamorphism.

The sample set from the Lemhi Range was originally analyzed for trace elements (reported by Baedecker and others, 1998) by the six-step semiquantitative spectrographic method (Golightly and others, 1987), except for 10 samples reported by Connor (1991a), which were analyzed by inductively coupled plasma-atomic absorption emission spectroscopy (Lichte and others, 1987). Some samples were analyzed for selected major oxides and trace elements by other methods (Baedecker and others, 1998), but these data were not used in this report. The formerly incomplete analyses of major oxides were supplanted by more recent analyses of all major oxides by X-ray fluorescence spectrometry (methods described by Taggart and others, 1987). These major oxide analyses are unpublished, but they are available in the electronic version of this report. Rock types represented in the sample set are mostly sandstone, siltite, and diamictite, but the distribution of samples among categories is unbalanced for statistical comparison (Table 1). At 78 samples, siltite is over-represented; at two samples, argillite is under-represented. Formations are likewise unequally represented; most sandstone samples (16) are from the Big Creek Formation, whereas diamictite is entirely from one unit of the Apple Creek Formation. Most siltite samples, however, are nearly evenly distributed among the Big Creek Formation and two units of the Apple Creek Formation, providing a good case for examining stratigraphic variation in those units. In general, rocks of the Lemhi Range are metamorphosed to lower greenschist grade (Tysdal, 1996a,1996b), less than those of the Salmon River Mountains.

The two data sets, edited for the present study, are archived in separate Excel files accompanying the electronic version of this report. Click here to download the Salmon River Mountains data set; click here to download the Lemhi Range data set.

\section{Acknowledgments}

We especially acknowledge J.J. Connor, who collected and documented samples for the Salmon River Mountains data set and part of the Lemhi Range data set, used in this study. 
Chemical analyses of rocks from the Salmon River Mountains (Connor (1990) were made by A.J. Bartel, E. Brandt, P.H. Briggs, S. Danahey, D. Fey, D.B. Hatfield, M. Malcolm, V. Merritt, G. Riddle, S. Roof, K. Stewart, J. Storey, J.E. Taggart, Jr., and R.B. Vaughn, U.S. Geological Survey. Analyses of rocks from the Lemhi Range were made by P.H. Briggs, D.E. Detra, D.L. Fey, R.T. Hopkins, J.M. Motooka, J.E. Taggart, Jr., and K. Slaughter, U.S. Geological Survey. Ten samples from the Lemhi Range (Connor, 1991a) were analyzed by A.J. Bartel, P.H. Briggs, R.R. Carlson, J.G. Crock, C.S.E. Papp, B.H. Roushey, D.F. Siems, J.E. Taggart, Jr., and E.P. Welsch, U.S.Geological Survey. R.G. Eppinger reviewed the manuscript.

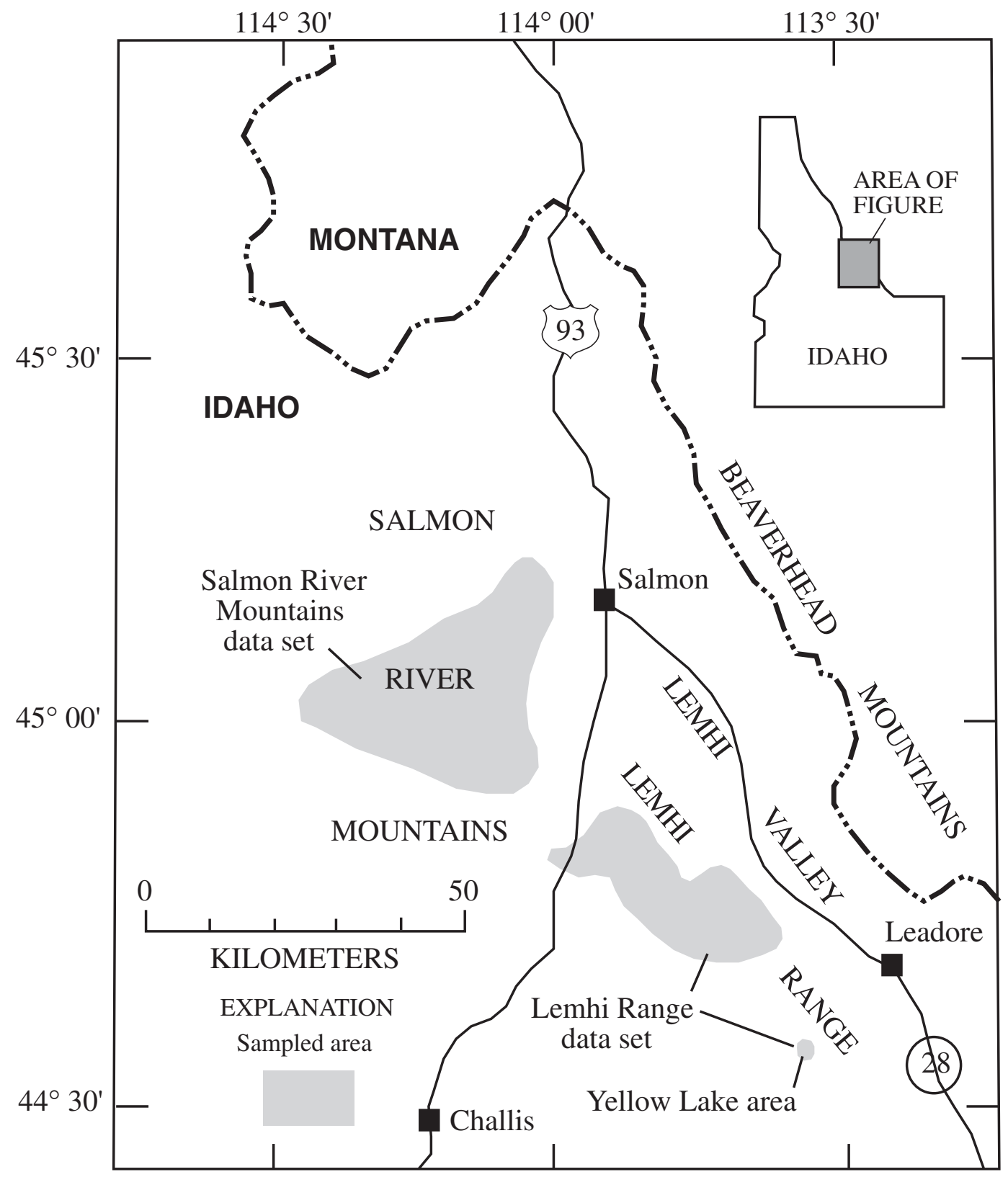

Figure 1.--Index map showing generalized location of samples for geochemical data sets for metasedimentary rocks of the Mesoproterozoic Lemhi Group, Salmon River Mountains and Lemhi Range, central Idaho. 
- 4 - 
Table 1.--Samples of metasedimentary rocks of the Mesoproterozoic Lemhi Group classified by formation (including facies and units) and rock type, Salmon River Mountains and Lemhi Range, central Idaho. Ygf, fluvial facies of Gunsight Formation; Ygm, marine facies of Gunsight Formation; Yay, Yellow Lake unit of Apple Creek Formation; Yab, banded siltite unit of Apple Creek Formation; Yac, coarse siltite unit of Apple Creek Formation; Yad, diamictite unit of Apple Creek Formation; Yaf, fine siltite unit of Apple Creek Formation; and Yb, Big Creek Formation. Formation nomenclature of Tysdal (2000a; 2000b).

\begin{tabular}{lccccc}
\hline Formation & Total & Sandstone & Siltite & Argillite & Diamictite \\
\hline \multicolumn{7}{c}{ Salmon River } & Mountains \\
Ygf & 11 & 7 & 0 & 4 & 0 \\
Ygm & 10 & 10 & 0 & 0 & 0 \\
Yab & 37 & 10 & 7 & 20 & 0 \\
Yac & 40 & 7 & 15 & 18 & 0 \\
Total & 98 & 34 & 22 & 42 & 0 \\
\hline \multicolumn{7}{c}{ Lemhi Range } \\
\hline Yay & 6 & 1 & 3 & 2 & 0 \\
Yac & 21 & 0 & 21 & 0 & 0 \\
Yad & 49 & 0 & 25 & 0 & 24 \\
Yaf & 15 & 7 & 8 & 0 & 0 \\
Yb & 36 & 16 & 20 & 0 & 0 \\
Unknown & 1 & 0 & 1 & 0 & 0 \\
Total & 128 & 24 & 78 & 2 & 24 \\
\hline
\end{tabular}




\section{SALMON RIVER MOUNTAINS \\ R-mode Factor Analysis}

The following discussion summarizes R-mode factor analysis of major oxides and trace elements for 98 samples (34 sandstones, 22 siltites, and 42 argillites) of the Apple Creek and Gunsight Formations, Salmon River Mountains (data of Connor, 1990). A discussion of R-mode factor analysis as employed here can be found in Cooley and Lohnes (1962). Steps in the analysis were:

1) Data preparation--Major oxide and trace element data were screened for suitability for statistical analysis and interpretation, values below the limit of analytical detection were replaced, and $\log$ transformations were applied to skewed frequency distributions.

2) Principal components analysis--A principal components analysis was performed on a $35 \mathrm{X} 35$ correlation matrix (R-matrix). The correlation matrix was solved for its latent roots (eigenvalues) and a new matrix specifying uncorrelated vectors (principal component axes) was calculated. The first four principal components were selected for rotation, based on the distribution of eigenvalues, communalities, and ease of interpretation.

3) Factor analysis and interpretation--Principal component axes were rotated to new, orthogonal (uncorrelated) axes using the Kaiser Varimax criterion. Rotated principal components were interpreted as petrologic processes, based on major oxide and trace element factor loadings, and supported by analysis of scattergrams and frequency distributions for selected elements.

At this point a note of caution about the use of factor analysis of compositional data is in order. Factor analysis of compositional data may be inappropriate because the theoretical sum of values in each row (sample) of the data matrix is 100 percent. This property, referred to as the "constant sum problem" in geochemistry (Chayes, 1960), constrains the values of correlation coefficients. Correlations are not free to range between -1 and +1 . Correlations for major constituents are forced toward negative values. Moreover, when the number of constituents is reduced and recalculated to 100 percent as is done, for example, during conversion to a volatilefree basis, the correlations change. Solutions to the constant sum problem have been proposed, only to be declared inadequate upon subsequent investigation. After this study was completed, an extensive discussion of the constant sum problem, accompanied by a new proposal for solution (Reyment and Savazzi, 1999), came to the first author's (Lindsey) attention.

For the current study, the quandry of the constant sum problem was addressed in four ways. First, our goal is identification of petrologic processes, not precise computation of factor matrices. Thus, factor analysis is merely a convenient method for screening large data sets for possible relationships of interest for petrogenetic interpretation. The numerical results of the factor analysis are only a guide to interpretation, and alternative interpretations from the same data are possible. Second, interpretations should be tested by examining more than one data set, or by analyzing subsets of one data set, and by using other statistical methods where appropriate. Third, interpretation is aided greatly by considering other information, such as the nature of minerals present and the probable genesis of these minerals. Other geological attibutes, such as likely depositional processes and environments, also guide interpretation. Fourth, the Salmon River Mountains data set was reanalyzed following the recommendations of Reyment and Savazzi (1999); results of the reanalysis are presented for comparison in an Appendix to this report.

\section{Data Preparation}

Preparation of data for factor analysis required deciding what variables to include in the factor analysis. For the 98 Salmon River Mountains samples, elements for which more than half of the reported values are below the limit of analytical detection were excluded. Values for $\mathrm{Mn}$ were used instead of the traditionally reported $\mathrm{MnO}$ because the latter contained 53 values below the limit of detection. LOI (loss on ignition) was included because, although it represents total volatile components, it probably consists of mostly water (including hydroxyl) in the Apple Creek and Gunsight Formations. Little to no carbonate was observed in thin sections. 
Some modifications of the data were introduced to facilitate analysis. Data for elements having fewer than half of their values below the lower limit of detection were judged suitable for inclusion in the factor analysis if "less than" values were replaced by real numbers. For most elements, replacement values were selected at $1 / 2$ the limit of detection; for $\mathrm{Na}_{2} \mathrm{O}, 2 / 3$ the limit was selected; and for $\mathrm{P}_{2} \mathrm{O}_{5}, 3 / 5$ the limit was selected (Table 2). In addition, values of many oxides and trace elements were transformed to logarithms. The need for transformation was determined by comparison of geometric and arithmetic means with the median and by the kurtosis of each frequency distribution (Table 3). Essentially, if the geometric mean more closely approximated the median value than the arithmetic mean or if the rounded skewness value exceeded 0.5 , values were transformed to logarithms. Table 3 summarizes descriptive statistics for those chemical variables having more than half their values above the limit of detection, and indicates which variables were transformed to logarithms. Statistics for some calculated variables are also summarized.

A final 35X35 R-matrix was calculated for input to principal components and factor analysis (Appendix Table 1). 
Table 2.--Replacement values, lower limit of detection, and number of replaced values, 98 samples (34 metasandstones, 22 siltites, and 42 argillites), Apple Creek and Gunsight Formations, Salmon River Mountains.

\begin{tabular}{lrrr}
\hline $\begin{array}{l}\text { Oxide or } \\
\text { element }\end{array}$ & $\begin{array}{c}\text { Replacement } \\
\text { value }\end{array}$ & $\begin{array}{l}\text { Lower limit } \\
\text { of detection }\end{array}$ & \multicolumn{2}{c}{$\begin{array}{c}\text { Number of } \\
\text { replaced } \\
\text { values }\end{array}$} \\
\hline \multicolumn{4}{c}{ Oxides in percent } \\
\hline $\mathrm{CaO}$ & 0.01 & 0.02 & 2 \\
$\mathrm{Na}_{2} \mathrm{O}$ & 0.10 & 0.15 & 4 \\
$\mathrm{P}_{2} \mathrm{O}_{5}$ & 0.03 & 0.05 & 18 \\
\hline \multicolumn{4}{c}{ Trace elements in parts per million } \\
\hline $\mathrm{B}$ & 10 & 20 & 13 \\
$\mathrm{Be}$ & 0.5 & 1 & 11 \\
$\mathrm{Ce}$ & 2 & 4 & 1 \\
$\mathrm{Co}$ & 0.5 & 1 & 1 \\
$\mathrm{Cu}$ & 0.5 & 1 & 10 \\
$\mathrm{La}$ & 1 & 2 & 1 \\
$\mathrm{Nd}$ & 2 & 4 & 1 \\
$\mathrm{~Pb}$ & 2 & 4 & 2 \\
$\mathrm{Sb}$ & 0.05 & 2 & 1 \\
$\mathrm{Sc}$ & 1 & 2 & 7 \\
$\mathrm{Y}$ & 1 & 1 & 24 \\
$\mathrm{Yb}$ & 0.5 & 4 & 7 \\
$\mathrm{Zn}$ & 2 & 0.10 & \\
\hline
\end{tabular}


Table 3.--Descriptive statistics for major oxides and trace elements for 98 samples (34 metasandstones, 22 siltites, and 42 argillites), Apple Creek and Gunsight Formations, Salmon River Mountains (calculated from data of Connor, 1990). Only oxides and elements for which more than half the values are above the lower limit of detection are listed. Statistics reflect replacement of "less than" values in Table 1. *, transformed to logarithms for factor analysis. $\mathrm{Fe}_{\mathrm{T}} \mathrm{O}_{3}$, total iron as $\mathrm{Fe}_{2} \mathrm{O}_{3}$; LOI, loss on ignition.

\begin{tabular}{|c|c|c|c|c|c|c|c|}
\hline $\begin{array}{l}\text { Oxide or } \\
\text { element }\end{array}$ & $\begin{array}{c}\text { Geometric } \\
\text { mean }\end{array}$ & Median & $\begin{array}{c}\text { Arithmetic } \\
\text { mean }\end{array}$ & $\begin{array}{c}\text { Standard } \\
\text { deviation }\end{array}$ & Variance & Skewness & Kurtosis \\
\hline \multicolumn{8}{|c|}{ Oxides in percent } \\
\hline $\mathrm{SiO}_{2}$ & 71.40 & 71.15 & 71.64 & 5.953 & 35.442 & .456 & .492 \\
\hline $\mathrm{Al}_{2} \mathrm{O}_{3}$ & 13.07 & 13.55 & 13.48 & 3.188 & 10.163 & .080 & 1.657 \\
\hline $\mathrm{Fe}_{\mathrm{T}} \mathrm{O}_{3} *$ & 4.70 & 4.79 & 5.21 & 2.358 & 5.562 & 1.029 & 1.777 \\
\hline $\mathrm{MgO}^{*}$ & 1.09 & 1.15 & 1.23 & .564 & .318 & .603 & .822 \\
\hline $\mathrm{CaO}^{*}$ & .27 & .31 & .47 & .489 & .239 & 2.021 & 5.037 \\
\hline $\mathrm{Na}_{2} \mathrm{O}$ & 1.78 & 2.22 & 2.22 & 1.074 & 1.154 & .011 & -.028 \\
\hline $\mathrm{K}_{2} \mathrm{O}$ & 3.44 & 3.79 & 3.80 & 1.538 & 2.365 & .383 & .215 \\
\hline $\mathrm{TiO}_{2}$ & .44 & .47 & .47 & .161 & .026 & -.083 & -.488 \\
\hline $\mathrm{P}_{2} \mathrm{O}_{5}$ & .08 & .09 & .09 & .038 & .001 & .371 & .049 \\
\hline LOI & 1.48 & 1.65 & 1.71 & .845 & .715 & .514 & -.072 \\
\hline \multicolumn{8}{|c|}{ Trace elements in parts per million } \\
\hline As* & 2.80 & 2.8 & 4.82 & 6.079 & 36.958 & 3.502 & 15.611 \\
\hline $\mathrm{B}^{*}$ & 35.860 & 40.0 & 52.663 & 100.09 & 10018.3 & 8.530 & 77.151 \\
\hline $\mathrm{Ba}^{*}$ & 635.61 & 680.0 & 715.85 & 337.14 & 113662. & 1.18 & 3.23 \\
\hline $\mathrm{Be}$ & 1.661 & 2.0 & 1.893 & .847 & .718 & .058 & -.527 \\
\hline $\mathrm{Ce}^{*}$ & 57.677 & 67.0 & 68.796 & 34.387 & 1182.45 & .640 & 1.460 \\
\hline $\mathrm{Co}^{*}$ & 7.203 & 8.0 & 8.842 & 6.311 & 39.823 & 2.865 & 12.296 \\
\hline $\mathrm{Cr}$ & 42.279 & 47.0 & 46.663 & 17.704 & 313.422 & -.114 & -.215 \\
\hline $\mathrm{Cu}^{*}$ & 7.514 & 7.0 & 35.235 & 121.909 & 14861.9 & 7.365 & 59.104 \\
\hline $\mathrm{Ga}^{*}$ & 16.131 & 17.0 & 17.214 & 6.177 & 38.149 & 1.161 & 4.417 \\
\hline $\mathrm{La}$ & 30.273 & 35.5 & 36.112 & 17.433 & 303.894 & .123 & -.496 \\
\hline $\mathrm{Li}^{*}$ & 18.450 & 20.0 & 21.582 & 11.626 & 135.153 & .615 & -.431 \\
\hline $\mathrm{Mn} *$ & 193.11 & 210.00 & 264.45 & 227.15 & 51597 & 2.643 & 11.320 \\
\hline $\mathrm{Nd}$ & 27.450 & 30.5 & 32.194 & 14.943 & 223.292 & .032 & -.555 \\
\hline $\mathrm{Ni}$ & 14.288 & 16.0 & 16.265 & 7.380 & 54.465 & .088 & -.900 \\
\hline $\mathrm{Pb}^{*}$ & 5.410 & 5.0 & 9.041 & 14.518 & 210.761 & 6.208 & 47.659 \\
\hline $\mathrm{Sb}^{*}$ & .384 & .40 & .477 & .361 & .131 & 2.562 & 9.540 \\
\hline Sc & 8.719 & 10.0 & 9.704 & 3.805 & 14.479 & -.121 & -.471 \\
\hline $\mathrm{Sr}^{*}$ & 74.557 & 75.50 & 88.684 & 51.757 & 2678.84 & 1.017 & .779 \\
\hline $\mathrm{Th}^{*}$ & 12.068 & 12.5 & 13.053 & 5.437 & 29.556 & 1.764 & 6.512 \\
\hline $\mathrm{U}$ & 3.216 & 3.4 & 3.486 & 1.301 & 1.692 & .177 & -.443 \\
\hline V & 43.180 & 48.5 & 47.969 & 19.214 & 369.164 & -.053 & -.585 \\
\hline $\mathrm{Y}^{*}$ & 11.488 & 13.0 & 16.235 & 11.608 & 134.738 & .724 & -.396 \\
\hline $\mathrm{Yb}^{*}$ & 1.470 & 2.0 & 1.878 & 1.221 & 1.490 & .765 & .332 \\
\hline $\mathrm{Zn} *$ & 22.768 & 31.5 & 38.765 & 37.458 & 1403.07 & 2.079 & 7.309 \\
\hline $\mathrm{Zr} *$ & 195.30 & 204.5 & 211.55 & 96.265 & 9266.93 & 3.902 & 26.674 \\
\hline
\end{tabular}

Principal Components Analysis

The purpose of principal component analysis is reduction of the number of variables, many of which may be correlated and therefore redundant, to a smaller number of uncorrelated variables, called "principal components." Principal components analysis must precede factor analysis, which involves further transformation (such as rotation) and interpretation. A principal 
components analysis was performed on the Salmon River Mountains data set using a 35X35 correlation matrix with unities in the diagonal. The correlation matrix was solved for its latent roots (eigenvalues) and a new matrix specifying uncorrelated vectors (eigenvectors, or principal component axes) was determined (Cooley and Lohnes, 1962).

Selection of the number of principal components to preserve for rotation and factor interpretation is not always obvious, as in the present case. Criteria for selection are discussed by Jackson (1993). The problem of the number of principal components to select for rotation was investigated by examining eigenvalue magnitude, by examining the eigenvalue distribution curve for the point before an obvious change in slope (root curve method), by comparing the eigenvalue distribution with the eigenvalues calculated from random data (broken-stick distribution), by examining communalities under various rotation scenarios, and by trial interpretation of rotated factors.

The best choices for selection of the number of principal components for rotation and interpretation are two, four, and nine. The first two eigenvalues account for 51.9 pct of total variance; the first four account for $65.2 \mathrm{pct}$; and the first nine eigenvalues account for $83.9 \mathrm{pct}$ (Table 4). Nine eigenvalues exceed the average eigenvalue of one, suggesting that nine principal components could be selected for rotation and interpretation by the criterion of eigenvalues $>1$ (Table 4). The eigenvalue curve shows a break in slope between principal components 4 and 5 , suggesting that four components might be a good choice for rotation by the root curve criterion (Fig. 2). Only the first two principal components exceed random eigenvalues of the broken-stick distribution, but components 3 and 4 are only slightly less than values for the broken-stick distribution. Preservation of only two principal components for rotation would be the conservative choice, but rotation of four principal components might still yield reliable results. Preservation of nine principal components risks interpretation of random variance. 
Table 4.--Eigenvalues and proportion of variance, principal components analysis of $35 X 35 \mathrm{R}-$ matrix, Apple Creek and Gunsight Formations, Salmon River Mountains.

\begin{tabular}{lll}
\hline $\begin{array}{l}\text { Eigenvalue } \\
\text { rank }\end{array}$ & Magnitude & $\begin{array}{l}\text { Variance } \\
\text { proportion }\end{array}$ \\
\hline Value 1 & 13.063 & .373 \\
Value 2 & 5.109 & .146 \\
Value 3 & 2.472 & .071 \\
Value 4 & 2.155 & .062 \\
Value 5 & 1.632 & .047 \\
Value 6 & 1.327 & .038 \\
Value 7 & 1.260 & .036 \\
Value 8 & 1.163 & .033 \\
Value 9 & 1.148 & .033 \\
Value 10 & .722 & .021 \\
Value 11 & .634 & .018 \\
Value 12 & .601 & .017 \\
Value 13 & .456 & .013 \\
Value 14 & .405 & .012 \\
Value 15 & .368 & .011 \\
Value 16 & .342 & .010 \\
Value 17 & .303 & .009 \\
\hline
\end{tabular}

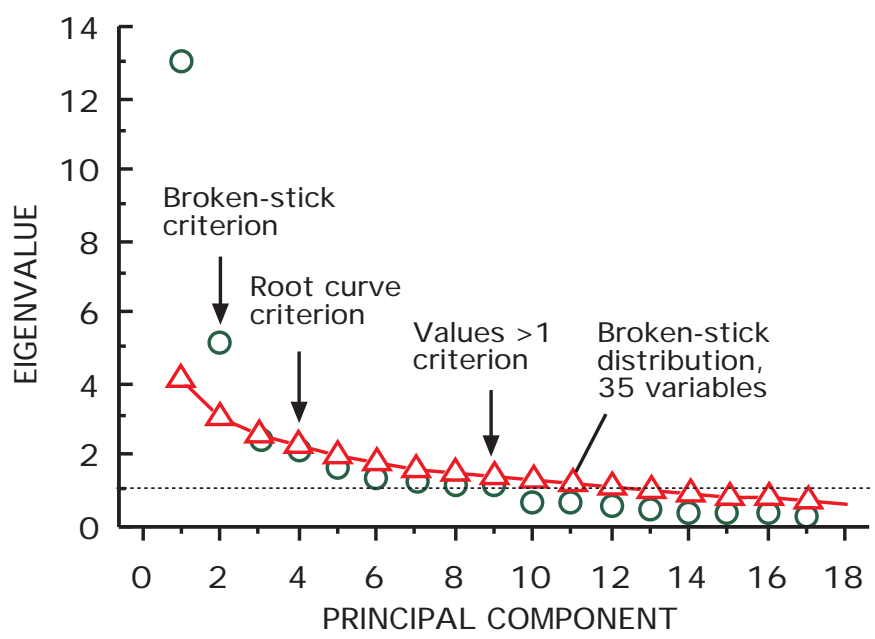

Figure 2.-- Eigenvalues compared to broken-stick distribution, showing possible choices for number of components to select for rotation, Apple Creek and Gunsight Formations, Salmon River Mountains. Values for Salmon River Mountains R-matrix shown by circles; random values (first 17 eigenvalues of 35-value broken-stick distribution) shown by triangles.

Communalities (Table 5), which measure the proportion of variance explained by the principal components preserved for rotation, provide additional insight into selection of the number of principal components. Communalities are low $(<0.50)$ for the 4-factor solution for $\mathrm{P}_{2} \mathrm{O}_{5}, \log \mathrm{As}, \log \mathrm{B}, \log \mathrm{Ba}, \log \mathrm{Cu}, \log \mathrm{Sb}$, and $\log \mathrm{Zr}$. Although communalities show major improvement when nine principal components are selected for rotation, values for many elements exceed the squared multiple correlation, a measure of maximum communality (Table 
5). Inspection of loadings of elements on nine factors (orthogonal Varimax rotation, not shown) revealed that some, notably $\mathrm{Cu}$ and $\mathrm{Zr}$, load alone on unique factors. Others, while loading with one or two other elements on a factor, are difficult to interpret. There is no basis for selecting a number of principal components between four and nine for rotation. The choice of four principal components for rotation and interpretation appears to be the best compromise. 
Table 5.--Communalities for 4- and 9-factor solutions, Apple Creek and Gunsight Formations, Salmon River Mountains. SMC, squared multiple correlation, the maximum expected communality; $h^{2}(4)$, communality estimate for 4-factor solution; $h^{2}(9)$, communality estimate for 9 -factor solution. Bold type, low $(<0.50)$ communalities for 4-factor solution. Italic type, communalities for 9-factor solution that exceed SMC. Best solution would have communality $>$ 0.50 but less than $\mathrm{SMC}$. $\mathrm{Fe}_{\mathrm{T}} \mathrm{O}_{3}$, total iron as $\mathrm{Fe}_{2} \mathrm{O}_{3}$; LOI, loss on ignition.

\begin{tabular}{|c|c|c|c|}
\hline Oxide or element & SMC & $h^{2}(4)$ & $h^{2}(9)$ \\
\hline $\mathrm{SiO}_{2}$ & .990 & .921 & .950 \\
\hline $\mathrm{Al}_{2} \mathrm{O}_{3}$ & .984 & .817 & .935 \\
\hline $\log \mathrm{Fe}_{\mathrm{T}} \mathrm{O}_{3}$ & .877 & .556 & .829 \\
\hline Log $\mathrm{MgO}$ & .869 & .611 & .800 \\
\hline $\mathrm{Log} \mathrm{CaO}$ & .895 & .821 & .862 \\
\hline $\mathrm{Na}_{2} \mathrm{O}$ & .921 & .702 & .865 \\
\hline $\mathrm{K}_{2} \mathrm{O}$ & .967 & .768 & .908 \\
\hline $\mathrm{TiO}_{2}$ & .948 & .821 & .910 \\
\hline $\mathrm{P}_{2} \mathrm{O}_{5}$ & .774 & .463 & .738 \\
\hline LOI & .919 & .622 & .810 \\
\hline $\log$ As & .646 & .422 & .726 \\
\hline Log B & .601 & .335 & .604 \\
\hline $\log \mathrm{Ba}$ & .846 & .372 & .856 \\
\hline $\mathrm{Be}$ & .857 & .701 & .826 \\
\hline $\log \mathrm{Ce}$ & .845 & .835 & .861 \\
\hline Log Co & .681 & .556 & .749 \\
\hline $\mathrm{Cr}$ & .909 & .580 & .921 \\
\hline $\log \mathrm{Cu}$ & .556 & .324 & .636 \\
\hline $\log \mathrm{Ga}$ & .952 & .835 & .905 \\
\hline $\mathrm{La}$ & .977 & .889 & .957 \\
\hline $\log \mathrm{Li}$ & .863 & .719 & .819 \\
\hline Log Mn & .827 & .665 & .779 \\
\hline $\mathrm{Nd}$ & .977 & .892 & .954 \\
\hline $\mathrm{Ni}$ & .858 & .616 & .882 \\
\hline $\log \mathrm{Pb}$ & .699 & .534 & .814 \\
\hline $\log \mathrm{Sb}$ & .621 & .318 & .804 \\
\hline $\mathrm{Sc}$ & .943 & .869 & .911 \\
\hline $\log \mathrm{Sr}$ & .832 & .756 & .834 \\
\hline Log Th & .799 & .646 & .818 \\
\hline $\mathrm{U}$ & .763 & .659 & .726 \\
\hline V & .961 & .803 & .945 \\
\hline Log Y & .900 & .690 & .891 \\
\hline $\log Y b$ & .883 & .649 & .866 \\
\hline $\log \mathrm{Zn}$ & .823 & .662 & .796 \\
\hline $\log \mathrm{Zr}$ & .789 & .370 & .841 \\
\hline
\end{tabular}


Table 6.--Orthogonal axes, 4 factors (Varimax rotation), Apple Creek and Gunsight Formations, Salmon River Mountains. Bold type, factor loadings $>[0.50]$ (absolute value); italic type, oxides or elements with communality $<0.50 . \mathrm{Fe}_{\mathrm{T}} \mathrm{O}_{3}$, total iron as $\mathrm{Fe}_{2} \mathrm{O}_{3}$; LOI, loss on ignition.

\begin{tabular}{|c|c|c|c|c|}
\hline Oxide or element & Factor 1 & Factor 2 & Factor 3 & Factor 4 \\
\hline $\mathrm{SiO}_{2}$ & -.950 & -.086 & -.092 & -.055 \\
\hline $\mathrm{Al}_{2} \mathrm{O}_{3}$ & .896 & .007 & -.028 & .117 \\
\hline $\log \mathrm{Fe}_{\mathrm{T}} \mathrm{O}_{3}$ & .379 & .198 & .426 & -.438 \\
\hline Log $\mathrm{MgO}$ & .727 & .223 & .177 & .040 \\
\hline $\log \mathrm{CaO}$ & .309 & .204 & .183 & .806 \\
\hline $\mathrm{Na}_{2} \mathrm{O}$ & -.268 & .053 & .107 & .785 \\
\hline $\mathrm{K}_{2} \mathrm{O}$ & .703 & -.002 & -.320 & -.415 \\
\hline $\mathrm{TiO}_{2}$ & .866 & .038 & . 191 & .182 \\
\hline $\mathrm{P}_{2} \mathrm{O}_{5}$ & .541 & .082 & .235 & .329 \\
\hline LOI & .742 & .037 & .259 & -.057 \\
\hline $\log A s$ & 197 & -.137 & .594 & .110 \\
\hline $\log B$ & .394 & .236 & -.350 & .042 \\
\hline $\log B a$ & .549 & .009 & -.145 & -.223 \\
\hline $\mathrm{Be}$ & .824 & .094 & -.086 & .075 \\
\hline $\log \mathrm{Ce}$ & .016 & .878 & .204 & .149 \\
\hline Log Co & .442 & .149 & .577 & -.073 \\
\hline $\mathrm{Cr}$ & .710 & -.080 & .192 & .179 \\
\hline $\log C u$ & -.137 & .113 & .535 & .079 \\
\hline $\log \mathrm{Ga}$ & .912 & .055 & .007 & -.017 \\
\hline $\mathrm{La}$ & .066 & .913 & .136 & .184 \\
\hline $\log \mathrm{Li}$ & .732 & .358 & .224 & .074 \\
\hline $\log M n$ & .241 & .276 & .659 & .311 \\
\hline $\mathrm{Nd}$ & .123 & .917 & .068 & .176 \\
\hline $\mathrm{Ni}$ & .660 & .171 & .327 & .210 \\
\hline $\log \mathrm{Pb}$ & -.080 & .097 & 688 & .213 \\
\hline $\log S b$ & .181 & .098 & .512 & .117 \\
\hline $\mathrm{Sc}$ & .913 & -.050 & .157 & .090 \\
\hline $\log \mathrm{Sr}$ & .097 & .232 & .141 & .820 \\
\hline Log Th & .721 & .352 & -.022 & .035 \\
\hline U & .649 & .394 & .288 & .027 \\
\hline V & .863 & -.137 & 199 & .018 \\
\hline Log Y & .262 & .523 & .244 & .537 \\
\hline $\log \mathrm{Yb}$ & .443 & .250 & .253 & .571 \\
\hline $\log \mathrm{Zn}$ & .149 & .170 & .782 & .008 \\
\hline $\log \mathrm{Zr}$ & .507 & .301 & .092 & -.116 \\
\hline
\end{tabular}

Factor 1--Micas and chlorite $\left(\mathrm{Al}_{2} \mathrm{O}_{3}, \log \mathrm{MgO}, \mathrm{K}_{2} \mathrm{O}, \mathrm{TiO}_{2}, \mathrm{LOI}, \mathrm{Be}, \mathrm{Cr}, \log \mathrm{Ga}, \log \mathrm{Li}, \mathrm{Ni}, \mathrm{Sc}, \log \mathrm{Th}, \mathrm{U}\right.$, and V) vs $\mathrm{SiO}_{2}$--grain size. $\mathrm{P}_{2} \mathrm{O}_{5}, \log \mathrm{Ba}$, and $\log \mathrm{Zr}$ have high loadings $(>0.50)$ but low communalities $(<0.50)$.

Factor 2--Rare earth minerals $(\log \mathrm{Ce}, \mathrm{La}, \mathrm{Nd}$, and $\log \mathrm{Y}$--provenance or metamorphism.

Factor 3--Base metals in $\mathrm{MnO}(\log \mathrm{Co}, \log \mathrm{Mn}, \log \mathrm{Pb}$, and $\log \mathrm{Zn}$ )--mineralization. $\log \mathrm{As}, \log \mathrm{Cu}, \operatorname{and} \log \mathrm{Sb}$ have high loadings $(>0.50)$ but low communalities $(<0.50)$.

Factor 4--Plagioclase $\left(\log \mathrm{CaO}, \mathrm{Na}_{2} \mathrm{O}, \log \mathrm{Sr}, \log \mathrm{Y}\right.$, and $\left.\log \mathrm{Yb}\right)$--provenance.

Factor Analysis and Interpretation

Four principal components were rotated by the Kaiser Varimax criterion, which maximizes the loadings of a few variables on each principal component while maintaining orthogonal axes (Cooley and Lohnes, 1962). The rotated matrix is much simpler to interpret than the unrotated matrix because, after rotation, only a few variables have large loadings on 
each principal component. It is common to refer to the principal components as "factors" after rotation (Table 6). Factor interpretation of the four principal components is, for the most part, straightforward: 1) micas and chlorite $\left(\mathrm{Al}_{2} \mathrm{O}_{3}, \log \mathrm{MgO}, \mathrm{K}_{2} \mathrm{O}, \mathrm{TiO}_{2}, \mathrm{LOI}, \mathrm{Be}, \mathrm{Cr}, \log \mathrm{Ga}, \log \mathrm{Li}\right.$, $\mathrm{Ni}, \mathrm{Sc}, \log \mathrm{Th}, \mathrm{U}$, and $\mathrm{V}$ vs $\mathrm{SiO}_{2}$ ), interpreted as grain size of original sediment, 2) rare earth minerals (log $\mathrm{Ce}, \mathrm{La}, \mathrm{Nd}$, and $\log \mathrm{Y})$, interpreted as provenance or metamorphism, 3) base metal minerals (log $\mathrm{Co}, \log \mathrm{Mn}, \log \mathrm{Pb}$, and $\log \mathrm{Zn}$ ), interpreted as mineralization, and 4) plagioclase $\left(\log \mathrm{CaO}, \mathrm{Na}_{2} \mathrm{O}, \log \mathrm{Sr}, \log \mathrm{Y}\right.$, and $\log \mathrm{Yb}$ ), interpreted as provenance (Table 6). Interpretation is the final test for the choice of number of principal components to preserve for rotation; the 4factor solution is quite amenable to interpretation.

Initial factor interpretations are based primarily on the genetic implications of oxides and elements that have loadings $>0.50$ on one factor--in other words, elements that have at least 0.25 $(0.50$ squared $)$ of their total variance explained by one factor. Elements having loadings $>0.50$ but low communalities $(<0.50$, less than half their variance) are generally compatible with the proposed interpretation but were given less consideration. (In comparing loadings to communalities, the communality is equal to the sum of the squares of the factor loadings).

The interpretation of factor 1 as a grain-size effect of the original sediment is evident from scattergrams of values classified by grain size-dependent rock type (Fig. 3). Values for oxides and trace elements that load positively on factor 1 are clearly elevated in argillite compared to values in sandstone; values for siltite are intermediate between those for argillite and sandstone. Factor 1 oxides and trace elements currently reside in muscovite, biotite, and chlorite, inasmuch as the Apple Creek and Gunsight Formations of the Salmon River Mountains have been metamorphosed to greenschist grade. At the time of deposition, however, factor 1 elements were concentrated in clay. The high loading of $\mathrm{K}_{2} \mathrm{O}$ on factor 1 reflects muscovite; the high loading of $\mathrm{TiO}_{2}$ reflects biotite or its alteration product, chlorite (see analyses in Deer and others, 1966; Herron and Matteson, 1993). The loading of $\log \mathrm{MgO}$, not $\log \mathrm{Fe}_{\mathrm{T}} \mathrm{O}_{3}$, suggests magnesian biotite and chlorite. Fitted lines for the highly correlated values of $\mathrm{TiO}_{2}, \mathrm{Sc}, \mathrm{Cr}$, and $\mathrm{V}$ approach 0, 0 coordinates (Fig. 3), suggesting that these elements reside principally in one mineral, probably biotite. In contrast, the positive intercept on the $\mathrm{Al}_{2} \mathrm{O}_{3}$ axis for the line fitted to $\mathrm{Al}_{2} \mathrm{O}_{3}$ versus $\mathrm{TiO}_{2}$ (Fig. 3A) indicates the presence of two or more minerals, not necessarily all related to factor 1 , containing $\mathrm{Al}_{2} \mathrm{O}_{3}$. As seen in thin sections of siltite and sandstone, both plagioclase and orthoclase are abundant and probably account for much remaining $\mathrm{Al}_{2} \mathrm{O}_{3}$.

The high loadings of $\mathrm{TiO}_{2}$ and, to a lesser extent, $\mathrm{P}_{2} \mathrm{O}_{5}$ on factor 1 may also reflect the presence of accessory minerals sphene and apatite, respectively, with mica. As seen in thin section, these minerals are common in rocks of the Salmon River Mountains. The loading of $\mathrm{TiO}_{2}$ on factor 1 probably represents contributions from both biotite and sphene. The loading of $\mathrm{P}_{2} \mathrm{O}_{5}$ on factor 1 probably represents apatite alone; $\mathrm{P}_{2} \mathrm{O}_{5}$ is not reported in mica (Deer and others, 1966). The high loading of LOI, loss on ignition, on factor 1 reflects the abundance of hydroxyl in mica. Carbonate minerals, which could contribute to LOI, were not seen in thin sections.

In addition to $\mathrm{Sc}, \mathrm{Cr}$, and $\mathrm{V}$, other trace elements with high loadings on factor 1 are $\mathrm{Be}$, $\log \mathrm{Ga}, \log \mathrm{Li}, \mathrm{Ni}, \log \mathrm{Th}$, and $\mathrm{U}$. All of these elements can be adsorbed or otherwise incorporated into clays and micas; some are associated with the detrital (including clay) fraction of black shales (Vine and Tourtelot, 1970).

Factors 1 and 4 account for major rock-forming constituents. Factor 4 will be discussed next, to provide background for a discussion of Lemhi Group rocks as complex mixtures. Factors 2 and 3 consist entirely of trace elements; these factors will be discussed last. 

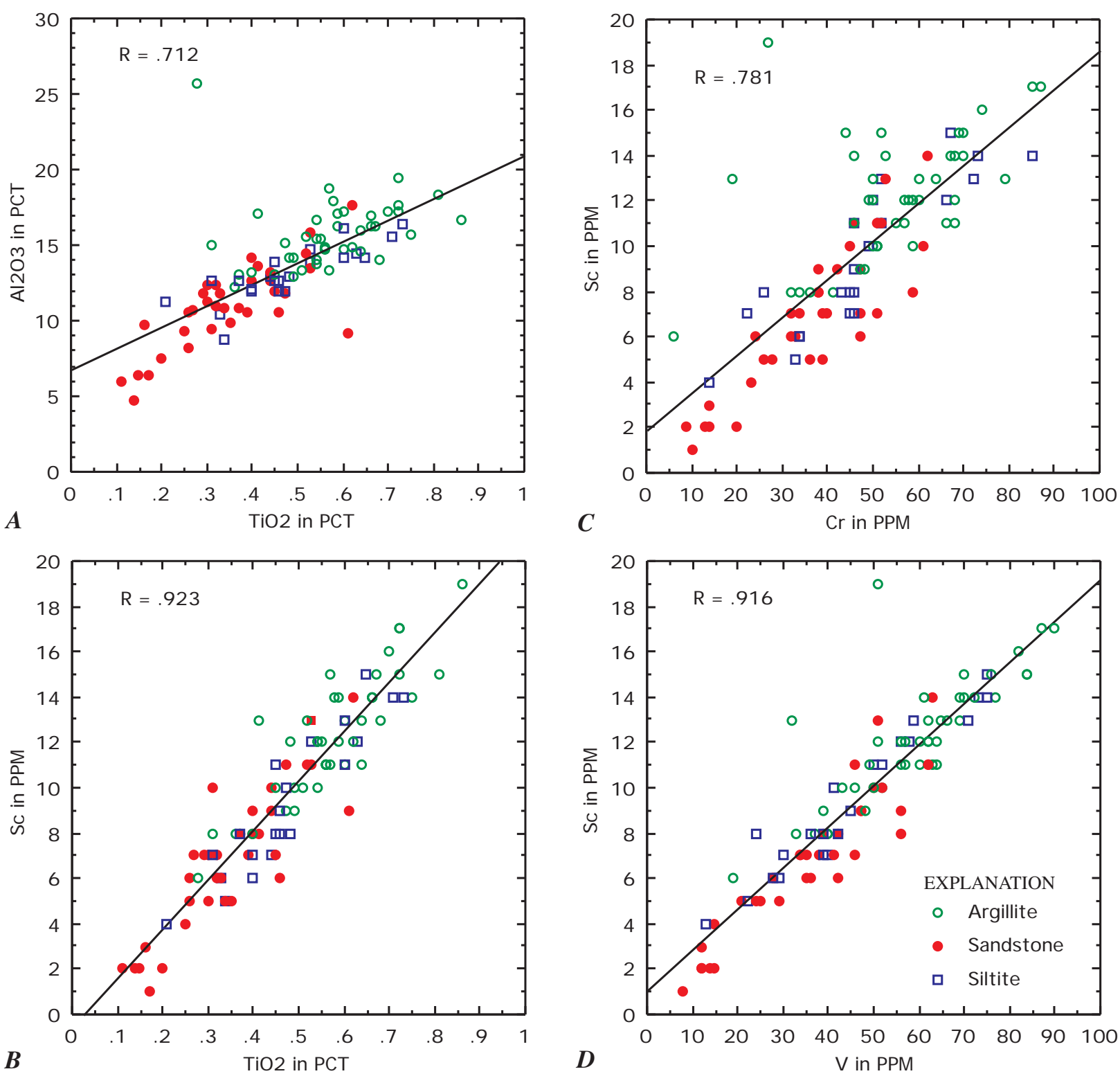

Figure 3.--Scattergrams of selected factor 1 oxides and elements, Apple Creek and Gunsight Formations, Salmon River Mountains: A) $\mathrm{Al}_{2} \mathrm{O}_{3}$ versus $\mathrm{TiO}_{2}$, B) Sc versus $\mathrm{TiO}_{2}$, C) Sc versus $\mathrm{Cr}$, and D) Sc versus V. R, correlation coefficient. Values classified by rock type. $\mathrm{R}$, correlation coefficient; lines are least-squares fit. PCT, weight percent; PPM, parts per million.

The interpretation of factor 4 as plagioclase is suggested by the high loadings of $\log \mathrm{CaO}$ and $\mathrm{Na}_{2} \mathrm{O}$. Both oxides are highly correlated, but are correlated most strongly in sandstones, where feldspar sand can be segregated from clay by currents (Fig. 4A). The linking of factor 4 to plagioclase is confirmed by the correlation of volume pct plagioclase, estimated from thin sections, with $\log \mathrm{CaO}$ and $\mathrm{Na}_{2} \mathrm{O}$ in sandstone (Fig. 4B). Strontium readily substitutes for $\mathrm{Ca}$ in plagioclase (Smith, 1975; Smith and Brown, 1988), and this relationship is readily observed in 
the high correlation of $\log \mathrm{Sr}$ with $\log \mathrm{CaO}$ (Fig. 4C). The logarithmic distribution of both elements is consistent with substitution in the same mineral. The correlation of $\mathrm{Na}_{2} \mathrm{O}$ with $\log \mathrm{Sr}$ is simply a consequence of the correlation of $\log \mathrm{CaO}$ with both $\mathrm{Na}_{2} \mathrm{O}$ and $\log \mathrm{Sr}$ (Fig. 4D). The moderate loadings of $\log \mathrm{Y}$ and $\log \mathrm{Yb}$ on factor 4 (Table 6) may also reflect substitution of those elements for $\mathrm{Ca}$ in plagioclase.

Plagioclase in arkose is generally a provenance indicator, reflecting the degree of preferential destruction of plagioclase over potassium feldspar during weathering in the source area and during transport to the depositional basin (e.g., Van de Kamp and Leake, 1994). Unstable grains including feldspar may be preferentially destroyed by diagenesis (e.g., Velbel and Saad, 1991); this process is observed in thin sections of immature sandstones. However, examples of diagenetic changes in the ratio of plagioclase to potassium feldspar, and accompanying chemical changes, are few. Exceptions include the well-documented replacement of potassium feldspar by albite in Ordovician graywackes in Quebec (Middleton, 1972) and the precipitation of albite cement in Jurassic arkose of the Connecticut River valley (Hubert and others, 1992). Chemical studies of graywackes in other terranes have yielded little evidence for sodium metasomatism (Floyd and others, 1991).

The major oxide composition of rocks in the Apple Creek and Gunsight Formations can be understood as the product of mixing of quartz, feldspar (alkali feldspar and plagioclase), muscovite, biotite, and chlorite (Fig. 5). Argast and Donnelly (1987) discuss mixing models in detrital rocks. Examination of thin sections reveals that all of these minerals are abundant in the Apple Creek and Gunsight Formations; most muscovite and biotite probably represent recrystallized clay. 

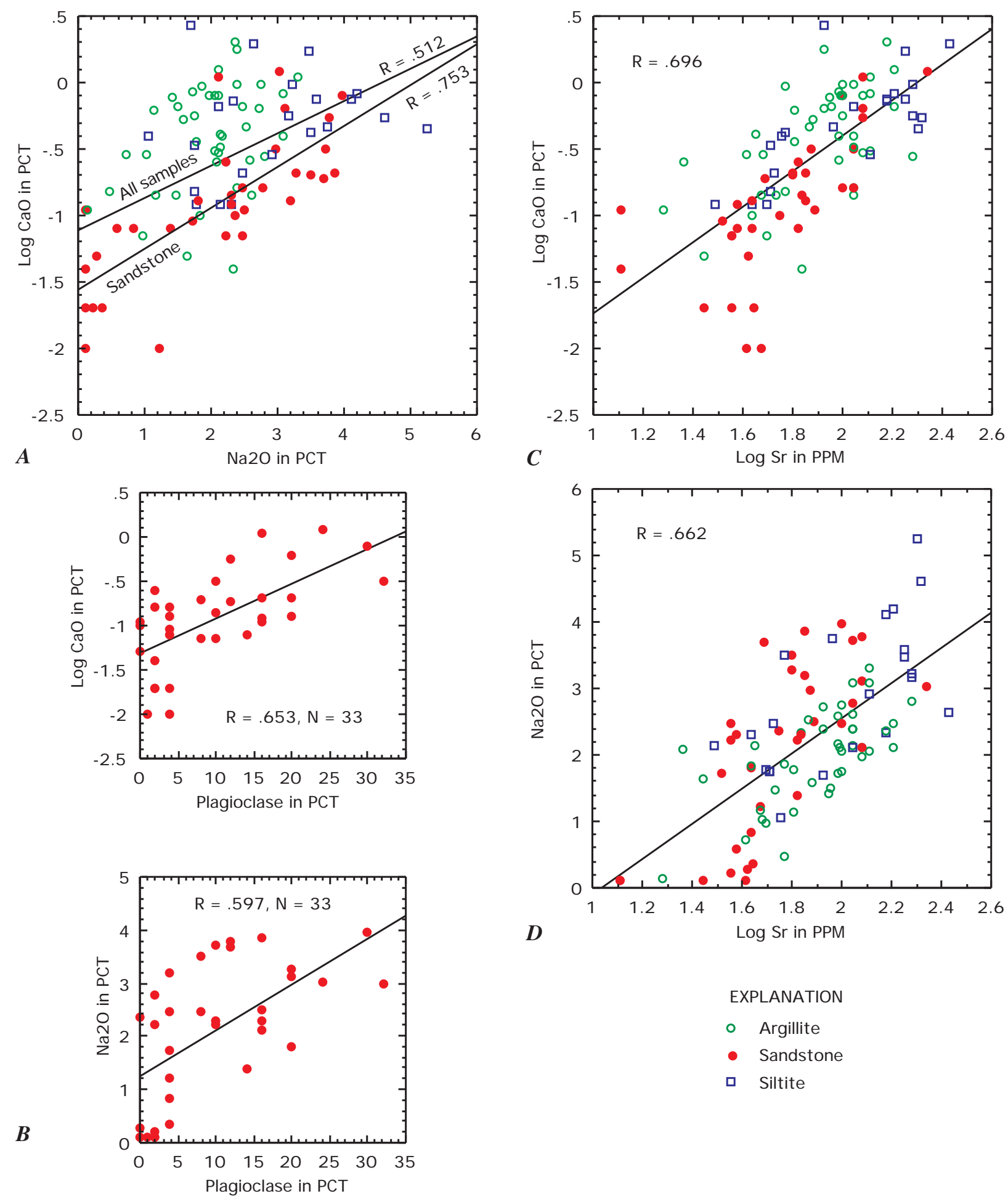

Figure 4.--Scattergrams of factor 4 oxides, elements, and plagioclase, Apple Creek and Gunsight Formations, Salmon River Mountains: A) $\log \mathrm{CaO}$ versus $\mathrm{Na}_{2} \mathrm{O}$, B) $\log \mathrm{CaO}$ and $\mathrm{Na}_{2} \mathrm{O}$ versus plagioclase, C) $\log \mathrm{CaO}$ versus $\log \mathrm{Sr}$, and D) $\mathrm{Na}_{2} \mathrm{O}$ versus $\log \mathrm{Sr}$. R, correlation coefficient; lines are least-squares fit. All chemical elements in weight percent (PCT) or parts per million (PPM); plagioclase in volume percent, estimated by J.J. Connor. 

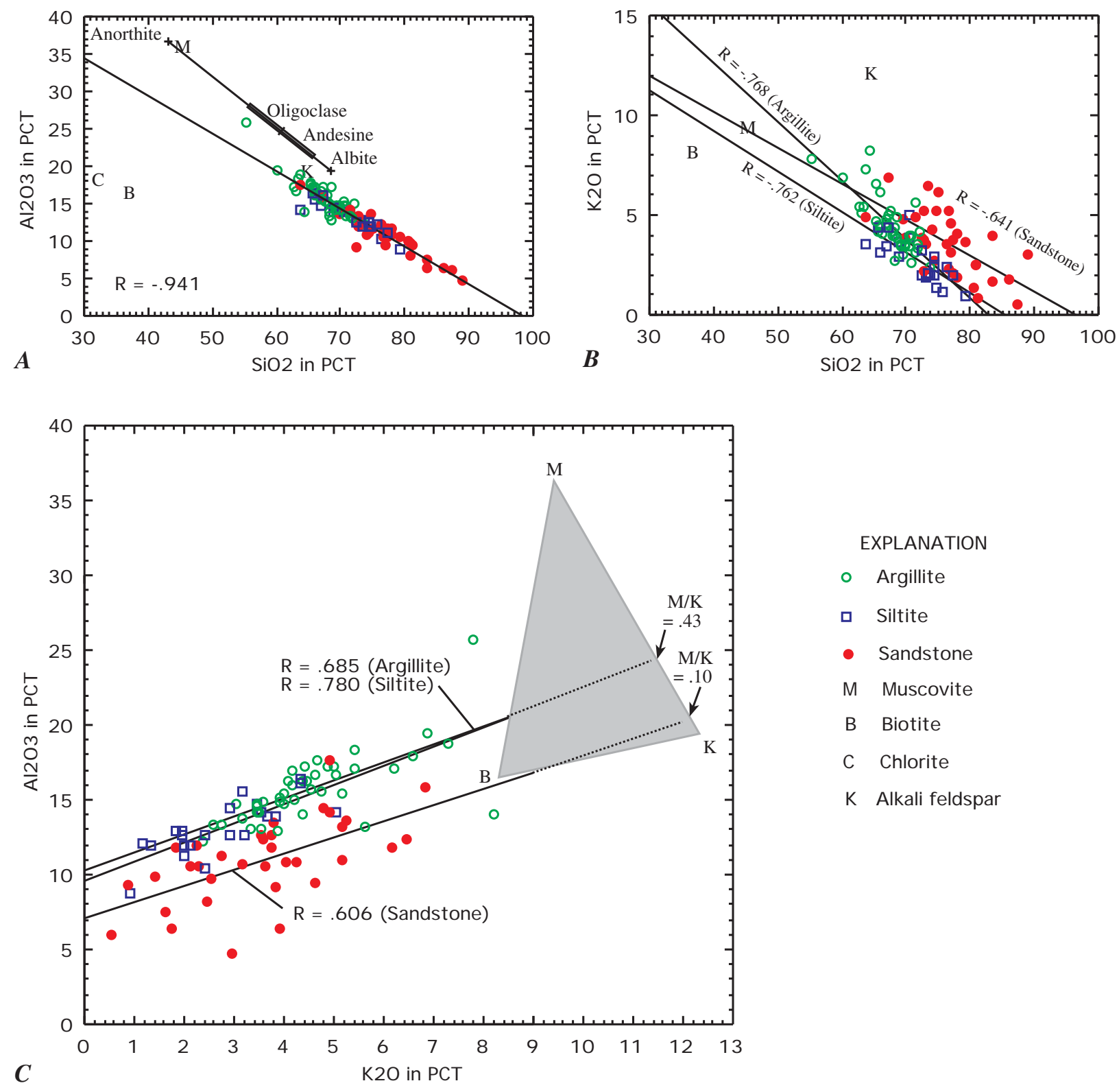

Figure 5.--Scattergrams illustrating mixtures of quartz $\left(\mathrm{SiO}_{2}\right)$, muscovite, biotite, alkali feldspar, and plagioclase to produce sandstone, siltite, and argillite of the Apple Creek and Gunsight Formations, Salmon River Mountains. A) $\mathrm{Al}_{2} \mathrm{O}_{3}$ versus $\mathrm{SiO}_{2}$, B) $\mathrm{K}_{2} \mathrm{O}$ versus $\mathrm{SiO}_{2}$, and C) $\mathrm{Al}_{2} \mathrm{O}_{3}$ versus $\mathrm{K}_{2} \mathrm{O}$. R, correlation coefficient; lines are least-squares fit. All oxides in weight percent (PCT). Values for muscovite, chlorite, albite, and anorthite are ideal compositions from Dana (1932); values for biotite, alkali feldspar, plagioclase, and andesine are averages of selected analyses from Deer and others $(1963,1966)$. Shaded triangle M-B-K is approximate composition range for mixtures of muscovite-biotite-alkali feldspar.

A line fitted to weight pct $\mathrm{Al}_{2} \mathrm{O}_{3}$ versus $\mathrm{SiO}_{2}$ intercepts the $\mathrm{SiO}_{2}$ axis near $100 \mathrm{pct}$, indicating that, as a first approximation, all rocks in the Apple Creek and Gunsight Formations can be viewed as mixtures of quartz and some combination of feldspar and mica (Fig. 5A). Although variable in composition (Deer and others, 1963), alkali feldspar lies near the fitted line. 
Thus, the $\mathrm{Al}_{2} \mathrm{O}_{3}$ and $\mathrm{SiO}_{2}$ contents of many samples, including most sandstone, could be achieved by simple mixtures of quartz and alkali feldspar. However, some argillite samples have more $\mathrm{Al}_{2} \mathrm{O}_{3}$ and less $\mathrm{SiO}_{2}$ than alkali feldspar. Only addition of some mixture of plagioclase, muscovite, biotite, or chlorite can produce high- $\mathrm{Al}_{2} \mathrm{O}_{3}$, low-SiO 2 argillites. The $\mathrm{Al}_{2} \mathrm{O}_{3} / \mathrm{SiO}_{2}$ line for plagioclase and the position of ideal (potassium) muscovite lies above the fitted line; values for biotite lie well below and to the left of the fitted line.

Lines fitted to $\mathrm{K}_{2} \mathrm{O}$ versus $\mathrm{SiO}_{2}$ in rocks of the Apple Creek and Gunsight Formations reveal that simple mixtures of quartz and alkali feldspar cannot account for $\mathrm{K}_{2} \mathrm{O}$ in these rocks; alkali feldspar does not fall on $\mathrm{K}_{2} \mathrm{O}$ versus $\mathrm{SiO}_{2}$ fitted lines for any rock type, but muscovite and biotite do (Fig. 5B). Moreover, simple mixtures of quartz and mica will not account for the fitted lines of argillite and siltite because the lines do not intercept $\mathrm{SiO}_{2}$ at 100 pct (pure quartz). Complex mixtures are required.

Fitted lines for weight pct $\mathrm{Al}_{2} \mathrm{O}_{3}$ versus $\mathrm{K}_{2} \mathrm{O}$ yield a complex mixing scenario (Fig. 5C). Lines for argillite and siltite are nearly identical, but the line for sandstone lies on a separate trend of lower $\mathrm{Al}_{2} \mathrm{O}_{3}$ values. All lines intersect a triangle defined by the weight pct $\mathrm{Al}_{2} \mathrm{O}_{3}$ versus $\mathrm{K}_{2} \mathrm{O}$ of biotite, muscovite, and alkali feldspar. Muscovite/potassium feldspar mixtures in proportions near 0.10 can be added to quartz to account for the sandstone line; proportions near 0.43 are required for the siltite and argillite lines. Slightly less weight percent of biotite can be substituted for alkali feldspar to produce equivalent $\mathrm{Al}_{2} \mathrm{O}_{3}$ values. Finally, both fitted lines intercept the $\mathrm{Al}_{2} \mathrm{O}_{3}$ axis above the origin, requiring addition of additional $\mathrm{Al}_{2} \mathrm{O}_{3}$-bearing minerals, probably plagioclase and chlorite. In thin section, both are seen to be abundant. When $\mathrm{K}_{2} \mathrm{O}=0$, an average 7 weight pct $\mathrm{Al}_{2} \mathrm{O}_{3}$ is present in sandstone and 10 pct $\mathrm{Al}_{2} \mathrm{O}_{3}$ is present in argillite and siltite.

Factor 2, defined by high loadings of $\log \mathrm{Ce}, \mathrm{La}, \mathrm{Nd}$ and, to a lesser extent $\log \mathrm{Y}$, evidently represents a rare-earth mineral. Scattergrams of $\mathrm{Ce}, \mathrm{La}$, and $\mathrm{Nd}$ reveal strong linear correlation, with fitted lines passing through the origin of all three plots (Figs. 6A-C). Most likely, these three elements reside principally in one mineral. Values of factor 2 elements, and their degree of correlation, does not vary with rock type (grain size), as might be expected if the rare earth elements were concentrated in micas (originally, detrital clay minerals). Thus, sediment sorting prior to metamorphism does not appear to be a likely interpretation for factor 2 .

In addition to clay, other candidates for the residence of rare earths are sphene, apatite, monazite, and carbonate minerals. Sphene and apatite are common in Mesoproterozoic rocks of the Salmon River Mountains; monazite and carbonate minerals are sparse. Rare earth elements are enriched in sphene (Deer and others, 1982; Bouch and others, 1997) and monazite (McLennan, 1989; Zhu and O’Nions, 1999).

Residence of monazite and apatite is not supported by covariation of $\mathrm{Ce}, \mathrm{La}$, and $\mathrm{Nd}$ with $\mathrm{P}_{2} \mathrm{O}_{5}$ (Fig. 6D). Although monazite has been tentatively identified in minute quantities in a few thin sections of the Gunsight Formation, it does not appear to be sufficiently abundant to account for variation in the abundance of rare earth elements. In thin sections of sandstone and siltite, the mineral identified as monazite is seen as small rounded grains of probable detrital origin. One complication of using covariation to test mineral residence may stem from the presence of accessory minerals in only minute amounts and by the presence of more than one phosphatebearing mineral. For example, the quantity of $\mathrm{P}_{2} \mathrm{O}_{5}$ contributed by accessory monazite is too small, relative to $\mathrm{P}_{2} \mathrm{O}_{5}$ in other minerals such as apatite, to affect $\mathrm{P}_{2} \mathrm{O}_{5}$ values in whole rock. Thus, variations in the quantity of a minute trace of another phosphate mineral will not be reflected in $\mathrm{P}_{2} \mathrm{O}_{5}$ values. 

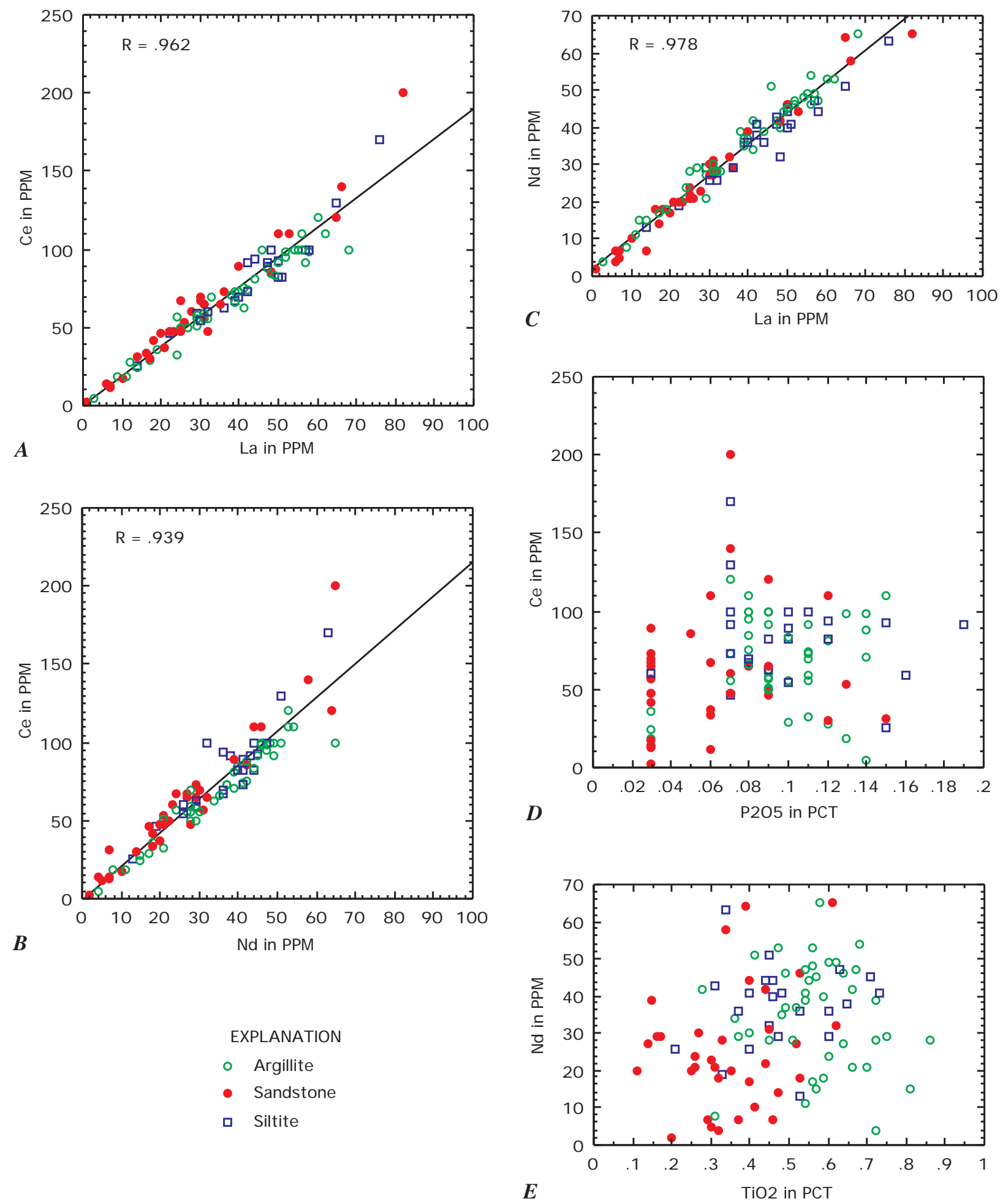

Figure 6.--Scattergrams of factor 2 trace elements and other selected oxides, Apple Creek and Gunsight Formations, Salmon River Mountains: A) Ce versus La, B) Ce versus Nd, C) Nd versus $\mathrm{La}, \mathrm{D}) \mathrm{Ce}$ versus $\mathrm{P}_{2} \mathrm{O}_{5}$, and E) Nd versus $\mathrm{TiO}_{2}$. R, correlation coefficient; lines are least-squares fit. R, correlation coefficient; lines are least-squares fit. PCT, weight percent; PPM, parts per million. 
Sphene is commonly observed in thin sections of the Apple Creek and Gunsight Formations. Most sphene in metasedimentary rocks of the Salmon River Mountains is probably of metamorphic origin, as indicated by the subhedral shape of some grains. Sphene is stable over a wide range of metamorphic environments, including low temperatures, under water-rich conditions (Hunt and Kerrick, 1977). To test the possibility that the rare earth trace elements of factor 2 represent sphene, scattergrams of $\mathrm{Ce}, \mathrm{La}$, and $\mathrm{Nd}$ versus $\mathrm{TiO}_{2}$ were examined ( $\mathrm{Nd}$ versus $\mathrm{TiO}_{2}$ shown in Fig. 6E). As expected from the factor loadings (Table 6), no covariation was found. As discussed for factor $1, \mathrm{TiO}_{2}$ values are affected by the abundance of mica, particularly biotite. Titania may also be present in iron oxide minerals and ilmenite. Thus, covariation of $\mathrm{TiO}_{2}$ with rare earth trace elements could well be masked by multiple mineral residences of $\mathrm{TiO}_{2}$.

Rare earth elements are susceptible to remobilization during diagenesis and low-grade metamorphism of argillaceous sediments (Ohr and others, 1994). In the original sediments, rare earth elements may reside in a variety of mineral phases, including carbonate minerals, clay, mica, apatite, sphene, and monazite. During metamorphism, some of these minerals, notably sphene and monazite, may form at the expense of soluble rare earth-bearing minerals, such as apatite.

In summary, factor 2 seems best interpreted as a measure of the abundance sphene, which is common in the Apple Creek and Gunsight Formations. Sphene may have been formed from metamorphism of a variety of rare-earth and titanium-bearing minerals, or it may have been recrystallized from detrital sphene. If the rare earth elements in Apple Creek and Gunsight Formations sediments were originally concentrated in detrital minerals, rare earths could reflect sediment provenance.

Factor 3 elements (logs of $\mathrm{As}, \mathrm{Co}, \mathrm{Cu}, \mathrm{Mn}, \mathrm{Pb}, \mathrm{Sb}$, and $\mathrm{Zn}$ ) are interpreted as base metals scavenged by manganese oxide, and are regarded as an indicator of mineralization.

Communalities for $\log \mathrm{As}, \mathrm{Cu}$, and $\mathrm{Sb}$ are low; these elements are represented poorly by factor 3 (Table 5). Correlation coefficients are generally weak among factor 3 elements, but each element is moderately correlated with one or more of the others (Table 7). Correlations between $\log \mathrm{Mn}, \log \mathrm{Pb}$ and $\log \mathrm{Zn}$ are strongest; $\log \mathrm{As}$ and $\log \mathrm{Sb}$ are weakly correlated with one another; $\log \mathrm{Co}$ is weakly correlated with $\log \mathrm{Mn}$; and $\log \mathrm{Cu}$ is weakly correlated with $\log \mathrm{Pb}$. Frequency distributions of all factor 3 elements are skewed by anomalously high values (Figs. 7 and 8), so much so that all required transformation to logarithms prior to calculation of linear correlation coefficients. Both skewing of frequency distributions toward a few high values and intercorrelation are considered evidence for mineralization.

Cobalt and copper are representative of mineralization in the Idaho cobalt belt of the Salmon River Mountains (Connor, 1990, 1991a). In the data set for the Salmon River Mountains, the frequency distributions of $\mathrm{Co}$ and $\mathrm{Cu}$ are skewed, but the distribution of $\mathrm{Cu}$ is skewed most (Table 3, Fig. 8). The overall abundance of Co in unmineralized metasedimentary rocks of the Salmon River Mountains appears to be the same as comparable clastic sedimentary rocks in the Belt basin, but copper may be more abundant in the Salmon River Mountains (Fig. 8). A few high values represent mineralized rock, but most values are near crustal levels and represent unmineralized rock. The weak correlation of factor 3 elements and the prevalence of crustal values in frequency distributions indicates that mineralization of rocks represented by the sample set was weak. Values for factor 3 elements in unmineralized rock were probably affected by other, unrecognized factors.

Iron did not load prominently on any factor (Table 6). Linear correlation coefficients for $\log \mathrm{Fe}_{\mathrm{T}} \mathrm{O}_{3}$ (total iron as $\mathrm{Fe}_{2} \mathrm{O}_{3}$ ) for oxides and trace elements that might be expected in iron oxide minerals (magnetite or hematite) or pyrite were examined for evidence of the separate occurrence of concentrations of these minerals (Table 8). Only log Co, and to some extent $\mathrm{TiO}_{2}$, have a tendency to correlate with $\log \mathrm{Fe}_{\mathrm{T}} \mathrm{O}_{3}$. Opaque iron minerals are commonly seen in thin sections of the Apple Creek and Gunsight Formations, and these evidently contain $\mathrm{TiO}_{2}$ and Co. Other trace elements, such as $\mathrm{Ba}, \mathrm{Cr}, \mathrm{Cu}, \mathrm{Mn}, \mathrm{Ni}, \mathrm{Sc}$, and $\mathrm{V}$, are not correlated with total iron. 
Table 7.--Linear correlation coefficients for factor 3 elements, Apple Creek and Gunsight Formations, Salmon River Mountains. Bold type, $\mathrm{R}=/>$ approximately 0.50 .

\begin{tabular}{lllllll}
\hline & $\log \mathrm{Co}$ & $\log \mathrm{Cu}$ & $\log \mathrm{Mn}$ & $\log \mathrm{Pb}$ & $\log \mathrm{Sb}$ & $\log \mathrm{Zn}$ \\
\hline Log As & .323 & .139 & .289 & .354 & $\mathbf{. 4 9 8}$ & .327 \\
$\log \mathrm{Co}$ & & .216 & $\mathbf{. 5 1 7}$ & .195 & .243 & .446 \\
$\log \mathrm{Cu}$ & & & .332 & .440 & .057 & .373 \\
$\log \mathrm{Mn}$ & & & & .483 & .299 & $\mathbf{. 7 3 0}$ \\
$\log \mathrm{Pb}$ & & & & & .421 & $\mathbf{. 5 8 6}$ \\
$\log \mathrm{Sb}$ & & & & & & .289 \\
\hline
\end{tabular}

Table 8.--Linear correlation coefficients between $\log \mathrm{Fe}_{\mathrm{T}} \mathrm{O}_{3}$ (total iron as $\mathrm{Fe}_{2} \mathrm{O}_{3}$ ), $\mathrm{TiO}_{2}, \log \mathrm{Ba}$, $\log \mathrm{Co}$, and $\log \mathrm{Mn}$, Apple Creek and Gunsight Formations, Salmon River Mountains. Bold type, $\mathrm{R}>0.50$.

\begin{tabular}{lcccc}
\hline & $\mathrm{TiO}_{2}$ & $\log \mathrm{Ba}$ & $\log \mathrm{Co}$ & $\log \mathrm{Mn}$ \\
\hline $\log \mathrm{Fe}_{\mathrm{T}} \mathrm{O}_{3}$ & .402 & .112 & $\mathbf{. 5 7 1}$ & .243 \\
$\mathrm{TiO}_{2}$ & & .331 & .441 & .333 \\
$\log \mathrm{Ba}$ & & & .094 & .049 \\
$\log \mathrm{Co}$ & & & & $\mathbf{. 5 1 7}$ \\
\hline
\end{tabular}



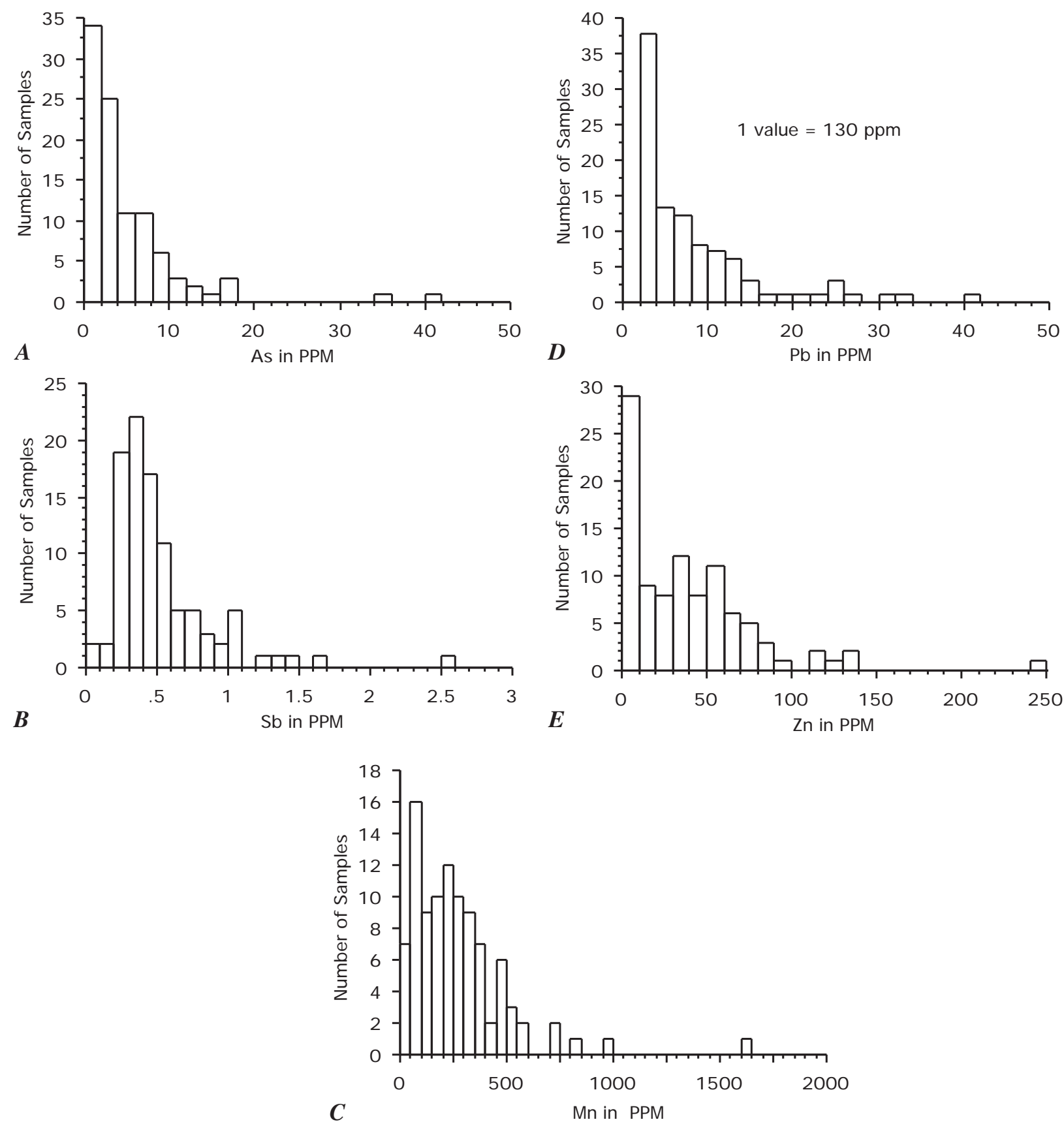

Figure 7.--Histograms showing frequency distributions of factor 3 elements $\mathrm{As}, \mathrm{Sb}, \mathrm{Mn}, \mathrm{Pb}$, and $\mathrm{Zn}$ in the Apple Creek and Gunsight Formations, Salmon River Mountains. PPM, parts per million. 

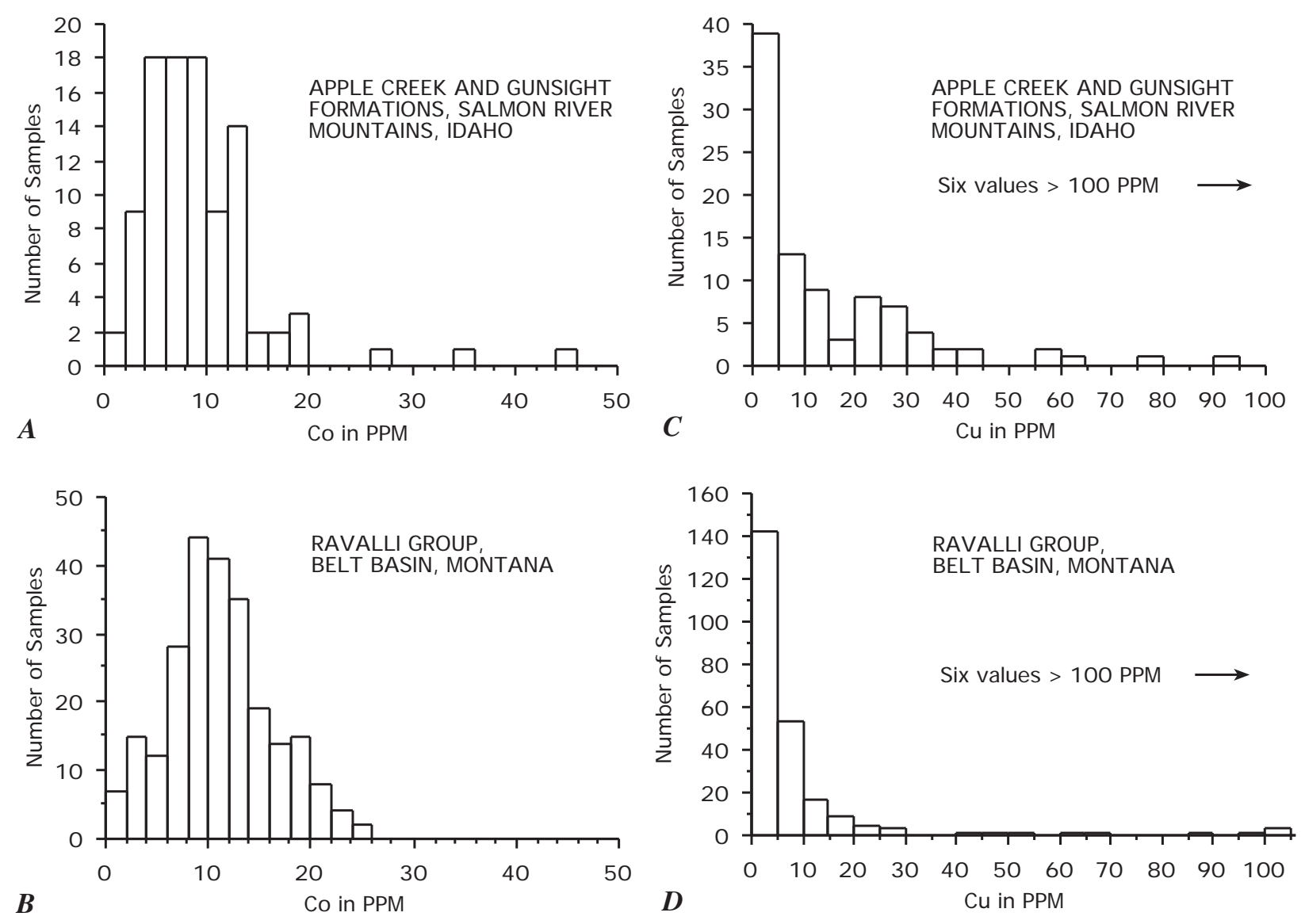

Figure 8.--Histograms comparing frequency distributions of cobalt and copper in the Apple Creek and Gunsight Formations, Salmon River Mountains, with the Ravalli Group, Belt basin, Montana: A) cobalt in the Apple Creek and Gunsight Formations, B) cobalt in the Ravalli Group, C) copper in the Apple Creek and Gunsight Formations, and D) copper in the Ravalli Group. Data for Ravalli Group from Connor (1991b). PPM, parts per million.

\section{Stratigraphic Variation}

Stratigraphic variation was investigated by analysis of variance. Briefly, because each rock type (sandstone, siltite, and argillite) is represented by two stratigraphic units (here termed "formations") of the Apple Creek Formation, and sandstone is also well-represented in a third unit, the Gunsight Formation (Table 1), an experiment could be set up to analyze the effects of both rock type and formation on any chemical constituent. Such "factorial experiments" (not to be confused with the factors of R-mode factor analysis) are discussed by Snedecor and Cochran (1967). In the experiment, each value for an oxide or trace element is classified by rock type and formation. The factorial analysis of variance has the advantage over other methods of identifying differences among categories (formations, rock types) in that it provides a way to assess multiple sources of variation. Unless one is held constant, effects of rock type on chemical composition might easily be confused with effects of stratigraphy. Moreover, effects of one can interact with the other, leading to incorrect interpretations of differences between categories.

For the initial analysis of variance, factor scores were analyzed. Scores for each sample were computed from the loadings of each chemical variable on the factor axes of Table 6 . The initial analysis permits ready identification of groups of chemical constituents that vary with stratigraphic unit and with rock type. Because the three rock types in the Salmon River 
Mountains data set are defined largely by grain size, effects of rock type are interpreted as effects of grain size, which in turn reflects mica content and, before metamorphism, clay content.

The analysis of variance (Table 9) shows significant effects of rock type on factor 1. This finding confirms the evidence from scattergrams of oxides and elements that load heavily on factor 1, that values for these chemical constituents vary with rock type (Figure 3). Factors 2 (rare earth minerals), interpreted as provenance or metamorphism, and factor 4 (plagioclase), interpreted as provenance, do not show effects of either rock type or formation. The lack of effects from either rock type or formation suggest uniform sediment provenance during deposition of the Gunsight Formation and the underlying banded siltite (Yab) and coarse siltite (Yac) units of the Apple Creek Formation. The only stratigraphic effect was found to be on factor 3 (base metals), interpreted as mineralization. In current stratigraphic terminology, samples from the banded siltite unit (Yab) of the Apple Creek Formation have the highest factor 3 scores (Fig. 9A). The banded siltite unit (Yab) contains the Blackbird mineralized zone of Connor (1991a). Finally, no evidence of interaction (in Table 9, rock type * formation) was found.

Plots of mean values for factors 3 and 4 illustrate the effects of formation and rock type on factor scores (Fig. 9). In the case of factor 3 (base metals), mean scores are uniformly high in the banded siltite unit (Yab) of the Apple Creek Formation (Fig. 9A). Among other formations and rock types, only mean scores for siltite are high in the coarse siltite unit (Yac) of the Apple Creek Formation. In contrast, although mean scores for factor 4 (plagioclase) are low for the Gunsight Formation, they also vary among rock types for each formation (Fig. 9B), so that no statistically significant differences among either rock types or formations can be detected (Table 9).

Scattergrams of several elements that load heavily on factor 4 (plagioclase) suggest a prevalence of low values in the Gunsight Formation (Fig. 10). However, the fluvial facies of the Gunsight contains some notably high values, and examination of thin sections shows a wide range in plagioclase content in the Gunsight. Perhaps, any differences in plagioclase content between the Gunsight and other formations are too subtle to be statistically demonstrable from the available data. The possibility of low plagioclase values for some parts of the Gunsight Formation merits further investigation. 
Table 9.--Analysis of variance for factor 1-4 scores and for element values with high loadings on factor 4, for differences among rock types and formations, Apple Creek and Gunsight Formations, Salmon River Mountains. Rock Type * Formation, interaction between rock type and formation; F-value, mean square of effect divided by residual mean square; P-value, probability of no difference among rock types or formations; $\mathbf{S}$, significant at $<0.05$ level.

Factor 1 scores

\begin{tabular}{llllll}
\hline & $\begin{array}{l}\text { Degrees of } \\
\text { Freedom }\end{array}$ & $\begin{array}{l}\text { Sum of } \\
\text { Squares }\end{array}$ & $\begin{array}{l}\text { Mean } \\
\text { Square }\end{array}$ & F-Value & P-Value \\
\hline Rock Type & 1 & 32.642 & 32.642 & 58.274 & $<.0001 \mathbf{S}$ \\
Formation & 1 & .019 & .019 & .034 & .8534 \\
Rock Type $*$ & 3 & .989 & .330 & .589 & .6239 \\
$\begin{array}{l}\text { Formation } \\
\text { Residual }\end{array}$ & 90 & 50.413 & .560 & & \\
\hline
\end{tabular}

Factor 2 scores

\begin{tabular}{llllll}
\hline & $\begin{array}{l}\text { Degrees of } \\
\text { Freedom }\end{array}$ & $\begin{array}{l}\text { Sum of } \\
\text { Squares }\end{array}$ & $\begin{array}{l}\text { Mean } \\
\text { Square }\end{array}$ & F-Value & P-Value \\
\hline Rock Type & 1 & 1.430 & 1.430 & 1.446 & .2323 \\
Formation & 1 & .165 & .165 & .167 & .6841 \\
Rock Type $*$ & 3 & 2.801 & .934 & .944 & .4230 \\
Formation & & & & & \\
Residual & 90 & 89.036 & .989 & & \\
\hline
\end{tabular}

Factor 3 scores

\begin{tabular}{llllll}
\hline & $\begin{array}{l}\text { Degrees of } \\
\text { Freedom }\end{array}$ & $\begin{array}{l}\text { Sum of } \\
\text { Squares }\end{array}$ & $\begin{array}{l}\text { Mean } \\
\text { Square }\end{array}$ & F-Value & P-Value \\
\hline Rock Type & 1 & .272 & .272 & .365 & .5472 \\
Formation & 1 & 4.528 & 4.528 & 6.077 & $.0156 \mathbf{S}$ \\
Rock Type $*$ & 3 & 2.965 & .988 & 1.327 & .2707 \\
Formation & & & & \\
Residual & 90 & 67.057 & .745 & & \\
\hline
\end{tabular}

Factor 4 scores

\begin{tabular}{llllll}
\hline & $\begin{array}{l}\text { Degrees of } \\
\text { Freedom }\end{array}$ & $\begin{array}{l}\text { Sum of } \\
\text { Squares }\end{array}$ & $\begin{array}{l}\text { Mean } \\
\text { Square }\end{array}$ & F-Value & P-Value \\
\hline Rock Type & 1 & .001 & .001 & .001 & .9706 \\
Formation & 1 & .424 & .424 & .533 & .4673 \\
Rock Type * & 3 & .264 & .088 & .110 & .9538 \\
Formation & & & & \\
Residual & 90 & 71.634 & .796 & & \\
\hline
\end{tabular}

Log $\mathrm{CaO}$ in percent

\begin{tabular}{llllll}
\hline & $\begin{array}{l}\text { Degrees of } \\
\text { Freedom }\end{array}$ & $\begin{array}{l}\text { Sum of } \\
\text { Squares }\end{array}$ & $\begin{array}{l}\text { Mean } \\
\text { Square }\end{array}$ & F-Value & P-Value \\
\hline Rock Type & 1 & 1.350 & 1.350 & 8.452 & $.0046 \mathbf{S}$ \\
Formation & 1 & .034 & .034 & .210 & .6476 \\
Rock Type $*$ & 3 & 1.066 & .355 & 2.224 & .0908 \\
\hline
\end{tabular}




\begin{tabular}{|c|c|c|c|c|c|}
\hline $\begin{array}{l}\text { Formation } \\
\text { Residual }\end{array}$ & 90 & 14.374 & .160 & & \\
\hline \multicolumn{6}{|c|}{$\mathrm{Na}_{2} \mathrm{O}$ values in percent } \\
\hline & $\begin{array}{l}\text { Degrees of } \\
\text { Freedom }\end{array}$ & $\begin{array}{l}\text { Sum of } \\
\text { Squares }\end{array}$ & $\begin{array}{l}\text { Mean } \\
\text { Square }\end{array}$ & F-Value & P-Value \\
\hline Rock Type & 1 & 3.532 & 3.532 & 4.174 & $.0440 \mathrm{~S}$ \\
\hline Formation & 1 & 1.561 & 1.561 & 1.845 & .1777 \\
\hline $\begin{array}{l}\text { Rock Type * } \\
\text { Formation }\end{array}$ & 3 & 5.733 & 1.911 & 2.258 & .0870 \\
\hline Residual & 90 & 76.155 & .846 & & \\
\hline \multicolumn{6}{|c|}{ Log Sr values in ppm } \\
\hline & $\begin{array}{l}\text { Degrees of } \\
\text { Freedom }\end{array}$ & $\begin{array}{l}\text { Sum of } \\
\text { Squares }\end{array}$ & $\begin{array}{l}\text { Mean } \\
\text { Square }\end{array}$ & F-Value & P-Value \\
\hline Rock Type & 1 & .056 & .056 & .932 & .3369 \\
\hline Formation & 1 & .026 & .026 & .434 & .5117 \\
\hline Rock Type * & 3 & .028 & .009 & .153 & .9274 \\
\hline Formation & & & & & \\
\hline Residual & 90 & 5.421 & .060 & & \\
\hline
\end{tabular}



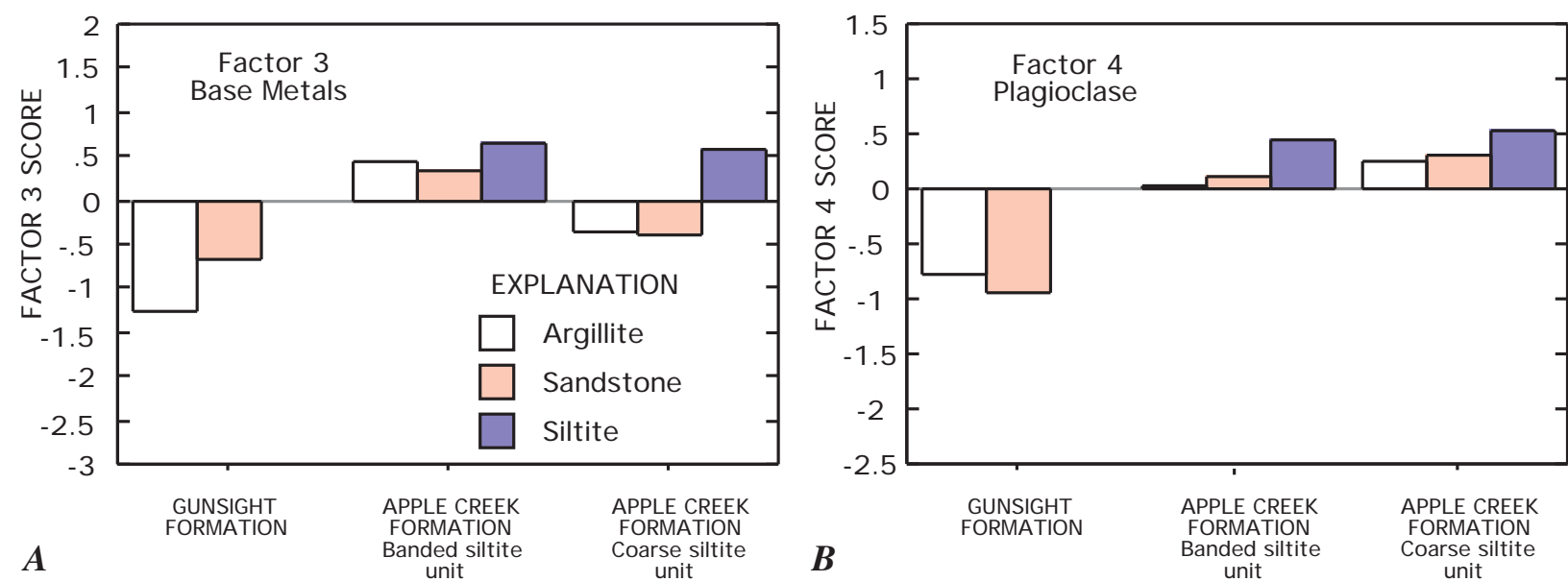

Figure 9.--Interaction bar charts showing mean scores by formation and rock type, Apple Creek and Gunsight Formations, Salmon River Mountains: A) factor 3 (base metals-mineralization) and B) factor 4 (plagioclase--provenance).
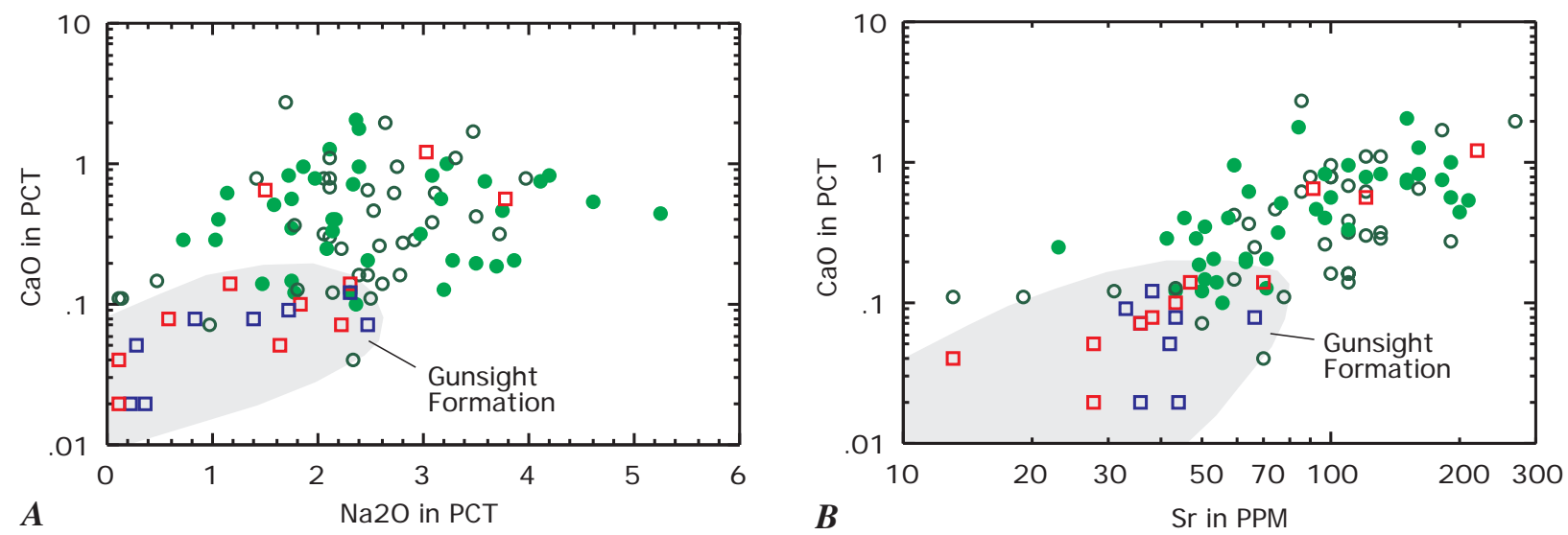

EXPLANATION

Gunsight Formation, fluvial

․ Gunsight Formation, marine

- Apple Creek Formation, banded siltite unit

- Apple Creek Formation, coarse siltite unit

Figure 10.--Scattergrams showing A) $\mathrm{CaO}$ versus $\mathrm{Na}_{2} \mathrm{O}$ and $\mathrm{B}$ ) $\mathrm{CaO}$ versus $\mathrm{Sr}$, Apple Creek and Gunsight Formations, Salmon River Mountains. Values for $\mathrm{CaO}$ and $\mathrm{Sr}$ are shown on logarithmic scales to facilitate direct reading. Three values for the Gunsight Formation fall outside the shaded area. PCT, weight percent: PPM, parts per million. 


\section{LEMHI RANGE \\ R-mode Factor Analysis}

The following discussion summarizes R-mode factor analysis of major oxides and trace elements for 128 samples (24 sandstones, 78 siltites, 2 argillites, and 24 diamictites) of the Big Creek and Apple Creek Formations in the Lemhi Range of Idaho. Refer to the section "Salmon River Mountains, R-mode Factor Analysis," for discussion of methods. The Lemhi Range data set differs somewhat in types of samples (Table 1) and analytical methods. Steps in the factor analysis were the same for both data sets. The analysis provides an independent test of the validity of the factor interpretation of the Salmon River data set.

\section{Data Preparation}

Preparation of the Lemhi Range data for factor analysis was similar to that of the Salmon River Mountains, with the following differences. Trace elements in rocks of the Lemhi Range were analyzed by the six-step semiquantitative spectrographic method (described by Golightly and others, 1987), whereby values in the geometric series $1,1.5,2,3,5,7,10$, etc., are assigned by visual comparison of selected spectral lines with standards. Thus, values were classified in a geometric series at the point of chemical analysis, and their frequency distribution must necessarily be treated as a geometric (logarithmic) function. Detection limits for the semiquantitative method were different from analyses for the same trace elements in rocks of the Salmon River Mountains. To prepare the data for statistical analysis, values below the lower limit of detection were replaced with the value for the next lower geometric class (Table 10). As with analyses of rocks from the Salmon River Mountains, elements for which more than half of the reported values were below the limit of analytical detection were excluded. The rule of 50 percent values above the lower limit of detection was relaxed slightly in order to permit consideration of $\mathrm{La}$ and $\mathrm{Pb}$. In the case of $\mathrm{Ba}$, five values above the upper limit of detection were replaced by the value of the next higher geometric class. Values for $\mathrm{MnO}$ were used instead of Mn because all values for MnO in Lemhi Range rocks are above the lower limit of detection.

Trace element data were transformed into logarithms because values were classified in a geometric series. The appropriateness of log transformation is confirmed by the high skewness values for all trace element distributions except $\mathrm{Ga}$ (Table 11). In addition, more of the major oxides required transformation to logarithms than was the case for data from the Salmon River Mountains. Frequency distributions for $\mathrm{Fe}_{\mathrm{T}} \mathrm{O}_{3}$ (total iron as $\mathrm{Fe}_{2} \mathrm{O}_{3}$ ), $\mathrm{MgO}, \mathrm{CaO}, \mathrm{Na}_{2} \mathrm{O}, \mathrm{TiO}_{2}$, $\mathrm{MnO}, \mathrm{P}_{2} \mathrm{O}_{5}$, and LOI (loss on ignition) in rocks of the Lemhi Range all have skewness values $>0.50$ (Table 11).

A 25X25 R-matrix was calculated for input to principal components and factor analysis (Appendix Table 2). 
Table 10.--Replacement values, lower limit of detection, and number of replaced values, 128 samples (24 sandstones, 78 siltites, 2 argillites, and 24 diamictites) of the Big Creek and Apple Creek Formations, Lemhi Range, Idaho. Seventeen samples not analyzed for Be and Ga; fourteen not analyzed for $\mathrm{Pb}$; five samples not analyzed for any trace element.

\begin{tabular}{lccc}
\hline Element & $\begin{array}{c}\text { Replacement } \\
\text { value }\end{array}$ & $\begin{array}{c}\text { Lower limit } \\
\text { of detection }\end{array}$ & $\begin{array}{c}\text { Number of } \\
\text { replaced } \\
\text { values }\end{array}$ \\
\hline $\mathrm{B}$ & Trace elements in parts per million \\
$\mathrm{Ba}$ & 7 & 10 & 5 \\
$\mathrm{Be}$ & 7000 & $5000^{*}$ & 5 \\
$\mathrm{Co}$ & 0.7 & 1 & 20 \\
$\mathrm{Cr}$ & 7 & 10 & 60 \\
$\mathrm{Cu}$ & 7 & 10 & 2 \\
$\mathrm{Ga}$ & 3 & 5 & 52 \\
$\mathrm{La}$ & 3 & 5 & 7 \\
$\mathrm{Ni}$ & 30 & 50 & 65 \\
$\mathrm{~Pb}$ & 3 & 5 & 10 \\
$\mathrm{Sc}$ & 7 & 10 & 68 \\
$\mathrm{Y}$ & 3 & 5 & 12 \\
\hline
\end{tabular}

*Upper limit of detection. 
Table 11.--Descriptive statistics for major oxides and trace elements, 128 samples (24 sandstones, 78 siltites, 2 argillites, and 24 diamictites) of the Big Creek and Apple Creek Formations, Lemhi Range, Idaho. Only oxides and elements for which approximately half or more of the values are above the lower limit of detection are listed. Statistics reflect replacement of "less than" values in Table 10. No., number of samples analyzed; Geom. Mean, geometric mean; Arith. Mean, arithmetic mean; Std. Dev., standard deviation; Var., variance; Skew., skewness; Kurt., kurtosis. *, transformed to logarithms for factor analysis. $\mathrm{Fe}_{\mathrm{T}} \mathrm{O}_{3}$, total iron as $\mathrm{Fe}_{2} \mathrm{O}_{3}$; LOI, loss on ignition.

\begin{tabular}{|c|c|c|c|c|c|c|c|c|}
\hline $\begin{array}{l}\text { Oxide or } \\
\text { Element }\end{array}$ & No. & $\begin{array}{l}\text { Geom. } \\
\text { Mean }\end{array}$ & Median & $\begin{array}{l}\text { Arith. } \\
\text { Mean }\end{array}$ & $\begin{array}{l}\text { Std. } \\
\text { Dev. }\end{array}$ & Var. & Skew. & Kurt. \\
\hline \multicolumn{9}{|c|}{ Oxides in percent } \\
\hline $\mathrm{SiO}_{2}$ & 128 & 71.584 & 71.200 & 71.891 & 6.670 & 44.494 & .286 & 1.899 \\
\hline $\mathrm{Al}_{2} \mathrm{O}_{3}$ & 128 & 11.545 & 12.500 & 12.114 & 3.178 & 10.100 & -.473 & .826 \\
\hline $\mathrm{Fe}_{\mathrm{T}} \mathrm{O}_{3}^{3} *$ & 128 & 4.654 & 4.835 & 5.395 & 3.102 & 9.623 & 1.624 & 3.498 \\
\hline $\mathrm{MgO}^{*}$ & 128 & 1.013 & 1.210 & 1.267 & .836 & .699 & 2.316 & 12.582 \\
\hline $\mathrm{CaO}^{*}$ & 128 & .267 & .225 & .548 & 1.076 & 1.157 & 4.582 & 23.735 \\
\hline $\mathrm{Na}_{2} \mathrm{O} *$ & 128 & 1.048 & 1.455 & 1.712 & 1.329 & 1.768 & .641 & -.319 \\
\hline $\mathrm{K}_{2} \mathrm{O}$ & 128 & 2.787 & 3.150 & 3.265 & 1.531 & 2.343 & .173 & -.474 \\
\hline $\mathrm{TiO}_{2} *$ & 128 & .421 & .465 & .470 & .276 & .076 & 6.268 & 56.765 \\
\hline $\mathrm{P}_{2} \mathrm{O}_{5}^{2} *$ & 128 & .183 & .190 & .188 & .046 & .002 & 2.920 & 19.413 \\
\hline $\mathrm{MnO}^{*}$ & 128 & .026 & .020 & .039 & .048 & .002 & 3.315 & 13.987 \\
\hline LOI* & 128 & 1.949 & 2.105 & 2.165 & 1.007 & 1.015 & 1.539 & 4.654 \\
\hline \multicolumn{9}{|c|}{ Trace elements in parts per million } \\
\hline $\mathrm{B}^{*}$ & 123 & 31.608 & 30 & 39.390 & 26.673 & 711.47 & 2.086 & 9.315 \\
\hline $\mathrm{Ba}^{*}$ & 123 & 756.962 & 700 & 1277 & 1500.7 & 2252310 & 2.514 & 6.552 \\
\hline $\mathrm{Be}^{*}$ & 113 & 1.714 & 2 & 1.858 & .768 & .590 & 1.326 & 3.327 \\
\hline $\mathrm{Co}^{*}$ & 123 & 10.078 & 7 & 11.602 & 8.012 & 64.192 & 3.729 & 21.692 \\
\hline $\mathrm{Cr}^{*}$ & 123 & 41.986 & 50 & 50.390 & 28.199 & 795.16 & .792 & .999 \\
\hline $\mathrm{Cu}^{*}$ & 123 & 8.319 & 5 & 41.780 & 169.572 & 28755 & 6.914 & 51.115 \\
\hline $\mathrm{Ga}^{*}$ & 113 & 29.726 & 30 & 33.814 & 15.541 & 241.53 & .359 & -.523 \\
\hline $\mathrm{La}^{*}$ & 123 & 38.086 & 30 & 40.463 & 14.276 & 203.81 & 1.064 & 1.584 \\
\hline $\mathrm{Ni}^{*}$ & 123 & 13.844 & 15 & 16.813 & 10.079 & 101.60 & 1.478 & 5.332 \\
\hline $\mathrm{Pb}^{*}$ & 113 & 9.513 & 10 & 11.655 & 18.473 & 341.25 & 9.528 & 94.378 \\
\hline $\mathrm{Sc}^{*}$ & 123 & 8.299 & 10 & 9.252 & 4.276 & 18.288 & 1.120 & 3.127 \\
\hline $\mathrm{V}^{*}$ & 123 & 57.893 & 70 & 65.862 & 30.952 & 958.02 & .655 & .728 \\
\hline $\mathrm{Y}^{*}$ & 123 & 32.802 & 30 & 37.358 & 20.823 & 433.59 & 2.036 & 6.829 \\
\hline $\mathrm{Zr}^{*}$ & 123 & 234.856 & 200 & 276.829 & 168.033 & 28235 & 1.494 & 2.506 \\
\hline
\end{tabular}




\section{Principal Components Analysis}

Selection of the number of principal components to preserve for rotation and factor interpretation was not obvious for the Lemhi Range data set. The best choices for selection of number of principal components for rotation and interpretation are one, four, and seven. The first eigenvalue accounts for 34 pct of total variance; the first four account for 59.4 pct, and the first seven eigenvalues account for 75.3 pct (Table 12). Seven eigenvalues exceed the average eigenvalue of 1 and could be selected for rotation and interpretation by the criterion of eigenvalues $>1$ (Table 12). Using the root curve (change in slope) criterion, 4 components might be a good choice for rotation (Fig.11). Only the first principal component exceeds random eigenvalues of the broken-stick distribution, but components 2, 3 and 4 are only slightly less than values for the broken-stick distribution. Preservation of only one principal component for rotation would be the conservative choice, but the resulting simple interpretation would have little petrogenetic value. Rotation of four principal components might still yield reliable results. Preservation of seven principal components risks interpretation of random variance.

Table 12.--Eigenvalues and proportion of variance, principal components analysis of 25X25 Rmatrix, Big Creek and Apple Creek Formations, Lemhi Range.

\begin{tabular}{lll}
$\begin{array}{l}\text { Eigenvalue } \\
\text { rank }\end{array}$ & Magnitude & $\begin{array}{l}\text { Proportion } \\
\text { of variance }\end{array}$ \\
\hline Value 1 & 8.491 & .340 \\
Value 2 & 2.691 & .108 \\
Value 3 & 1.912 & .076 \\
Value 4 & 1.791 & .072 \\
Value 5 & 1.482 & .059 \\
Value 6 & 1.278 & .051 \\
Value 7 & 1.193 & .048 \\
Value 8 & .939 & .038 \\
Value 9 & .776 & .031 \\
Value 10 & .625 & .025 \\
Value 11 & .584 & .023 \\
Value 12 & .475 & .019 \\
\hline
\end{tabular}

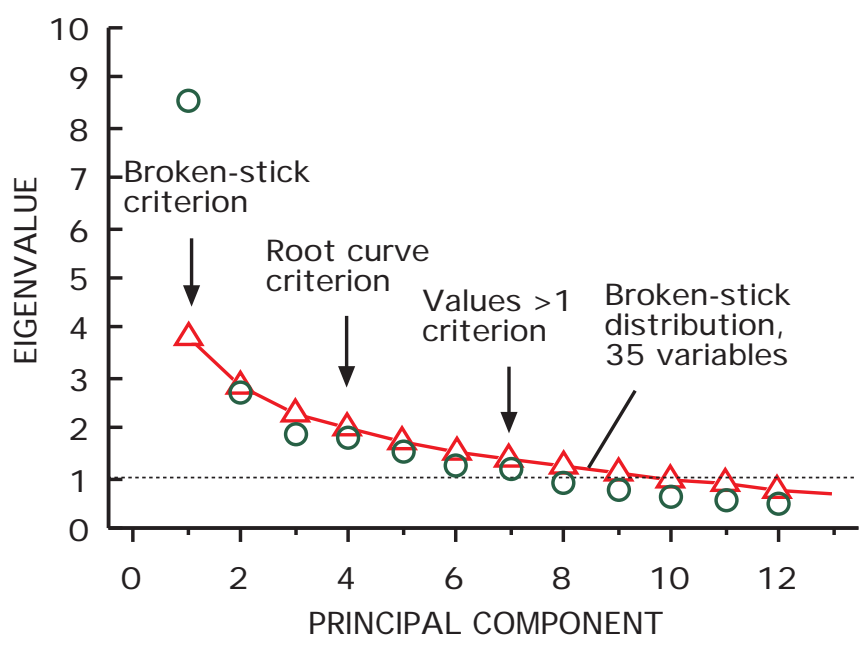


Figure 11.--Eigenvalues compared to broken-stick distribution, showing possible choices for number of components to select for rotation, Big Creek and Apple Creek Formations, Lemhi Range. Values for Lemhi Range R-matrix shown by circles; random values (first 12 eigenvalues of 25-value broken-stick distribution) shown by triangles.

Communalities are low $(<0.50)$ for many elements when only one principal component is rotated but approach squared multiple correlation values when four principal components are rotated (Table 13). Communalities for many elements exceed the squared multiple correlation when seven principal components are rotated, suggesting that this solution would risk interpretation of random variance. The choice of four principal components for rotation and interpretation appears to be the best compromise. 
Table 13.-- Communalities for 1-, 2-, 3-, 4-, and 7-factor solutions, Big Creek and Apple Creek Formations, Lemhi Range. SMC, squared multiple correlation, the maximum expected communality; $h^{2}(1)$ through $h^{2}(7)$, communality estimates for 1 - through 7 -factor solutions. Bold type, low $(<0.50)$ communalities for $1-4$ factor solutions. Italic type, communalities that exceed $\mathrm{SMC}$. Best solution would have communalities $>0.50$ but less than SMC. $\mathrm{Fe}_{\mathrm{T}} \mathrm{O}_{3}$, total iron as $\mathrm{Fe}_{2} \mathrm{O}_{3}$; LOI, loss on ignition.

\begin{tabular}{|c|c|c|c|c|c|c|}
\hline Oxide or element & SMC & $\mathrm{h}^{2}(1)$ & $\mathrm{h}^{2}(2)$ & $\mathrm{h}^{2}(3)$ & $\mathrm{h}^{2}(4)$ & $\mathrm{h}^{2}(7)$ \\
\hline $\mathrm{SiO}_{2}$ & .958 & .741 & .781 & .813 & .850 & .888 \\
\hline $\mathrm{Al}_{2} \mathrm{O}_{3}$ & .944 & .641 & .642 & .676 & .683 & .922 \\
\hline $\log \mathrm{Fe}_{\mathrm{T}} \mathrm{O}_{3}$ & .908 & .377 & .578 & .587 & .644 & .767 \\
\hline Log $\mathrm{MgO}$ & .599 & .155 & .163 & .504 & .732 & .741 \\
\hline $\log \mathrm{CaO}$ & .781 & .000 & .660 & .675 & .675 & .840 \\
\hline $\log \mathrm{Na}_{2} \mathrm{O}$ & .810 & .003 & .334 & .442 & .705 & .868 \\
\hline $\mathrm{K}_{2} \mathrm{O}$ & .906 & .532 & .646 & .654 & .661 & .840 \\
\hline $\log \mathrm{TiO}_{2}$ & .888 & .731 & .780 & .795 & .806 & .856 \\
\hline $\log \mathrm{P}_{2} \mathrm{O}_{5}$ & .747 & .341 & .559 & .572 & .582 & .775 \\
\hline Log MnO & .569 & .001 & .117 & .117 & .191 & .862 \\
\hline Log LOI & .656 & .256 & .256 & .279 & .536 & .811 \\
\hline $\log B$ & .718 & .438 & .441 & .560 & .686 & .780 \\
\hline $\log \mathrm{Ba}$ & .729 & .306 & .542 & .607 & .654 & .818 \\
\hline $\log B e$ & .646 & .293 & .377 & .422 & .484 & .779 \\
\hline Log Co & .471 & .073 & .157 & .484 & .497 & .668 \\
\hline $\log \mathrm{Cr}$ & .730 & .422 & .611 & .611 & .625 & .683 \\
\hline $\log \mathrm{Cu}$ & .459 & .064 & .257 & .338 & .479 & .627 \\
\hline $\log \mathrm{Ga}$ & .796 & .631 & .632 & .651 & .663 & .729 \\
\hline $\log \mathrm{La}$ & .323 & .208 & .228 & .273 & .274 & .444 \\
\hline $\log \mathrm{Ni}$ & .658 & .290 & .296 & .643 & .705 & .758 \\
\hline $\log \mathrm{Pb}$ & .309 & .055 & .061 & .079 & .355 & .605 \\
\hline $\log \mathrm{Sc}$ & .822 & 692 & 698 & .733 & .758 & .803 \\
\hline Log V & .773 & .649 & .682 & .706 & .712 & .719 \\
\hline $\log \mathrm{Y}$ & .482 & .240 & .264 & .357 & .357 & .496 \\
\hline $\log \mathrm{Zr}$ & .642 & .351 & .422 & .516 & .569 & .759 \\
\hline
\end{tabular}

Factor Analysis and Interpretation

Four principal components were rotated by the Kaiser Varimax criterion. Interpretation of the four orthogonal factors is straightforward: 1) micas (grain size of original sediment), 2) plagioclase (provenance), 3) chlorite (grain size), and 4) iron oxide minerals (placer concentration or mineralization) (Table 14). A factor for rare earth minerals (provenance or metamorphism), seen in factor analysis of Salmon River data, was not detected. Cerium and Nd were not analyzed; La and Y, which were analyzed, load on factor 1, but their low communalities indicate that they may belong to another, unidentified factor or factors. The 4factor solution of Lemhi Range data yields two grain size factors, a somewhat more complicated interpretation than desired. Interpretation of the fourth factor, iron oxide minerals, is also ambiguous. Nevertheless, examination of two- and three-factor solutions yielded no better matrix for interpretation. 
Table 14.--Orthogonal axes, 4 factors (Varimax rotation), Big Creek and Apple Creek Formations, Lemhi Range. Bold type, factor loadings $>[0.50]$ (absolute value); italic type, oxides or elements with communalities $<0.50$. $\mathrm{Fe}_{\mathrm{T}} \mathrm{O}_{3}$, total iron as $\mathrm{Fe}_{2} \mathrm{O}_{3}$; LOI, loss on ignition.

\begin{tabular}{|c|c|c|c|c|}
\hline Oxide or element & Factor 1 & Factor 2 & Factor 3 & Factor 4 \\
\hline $\mathrm{SiO}_{2}$ & -.566 & -.044 & -.335 & -.644 \\
\hline $\mathrm{Al}_{2} \mathrm{O}_{3}$ & .584 & .161 & .378 & .417 \\
\hline $\log \mathrm{Fe}_{\mathrm{T}} \mathrm{O}_{3}$ & .329 & -.157 & .155 & .698 \\
\hline $\log \mathrm{MgO}$ & .102 & -.120 & .839 & .057 \\
\hline $\log \mathrm{CaO}$ & .163 & .662 & .115 & -.443 \\
\hline $\log \mathrm{Na}_{2} \mathrm{O}$ & -.034 & .834 & .017 & .095 \\
\hline $\mathrm{K}_{2} \mathrm{O}$ & .583 & -.306 & .217 & .425 \\
\hline $\log \mathrm{TiO}_{2}$ & .703 & .302 & .340 & .324 \\
\hline $\log \mathrm{P}_{2} \mathrm{O}_{5}$ & .542 & .475 & .243 & .063 \\
\hline $\log M n O$ & .088 & .405 & -.137 & -.014 \\
\hline Log LOI & .416 & -.231 & .553 & -.061 \\
\hline $\log B$ & .776 & -.242 & .141 & -.072 \\
\hline $\log \mathrm{Ba}$ & .433 & -.316 & -.128 & .592 \\
\hline $\log B e$ & .515 & -.408 & .144 & .181 \\
\hline $\log C o$ & -.125 & .041 & .477 & .503 \\
\hline $\log \mathrm{Cr}$ & .670 & .294 & .293 & -.063 \\
\hline $\log \mathrm{Cu}$ & -.077 & -.027 & .110 & .679 \\
\hline $\log \mathrm{Ga}$ & .708 & .012 & . 109 & 387 \\
\hline $\log L a$ & .511 & 然78 & -.029 & .081 \\
\hline Log Ni & .233 & .138 & .777 & 167 \\
\hline $\log P b$ & .170 & 194 & -.296 & .448 \\
\hline Log Sc & .784 & .119 & .059 & .354 \\
\hline Log V & .785 & .159 & .120 & .234 \\
\hline $\log Y$ & .593 & .032 & -.062 & .026 \\
\hline $\log \mathrm{Zr}$ & .736 & .001 & .088 & -.138 \\
\hline
\end{tabular}

Factor 1--Micas $\left(\mathrm{Al}_{2} \mathrm{O}_{3}, \mathrm{~K}_{2} \mathrm{O}, \log \mathrm{TiO}_{2}, \log \mathrm{P}_{2} \mathrm{O}_{5}, \log \mathrm{B}, \log \mathrm{Cr}, \log \mathrm{Ga}, \log \mathrm{Sc}, \log \mathrm{V}, \operatorname{and} \log \mathrm{Zr}\right)$ vs $\mathrm{SiO} 2^{--}$grain size. $\log \mathrm{Be}, \log \mathrm{La}$, and $\log \mathrm{Y}$ have high loadings $(>0.50)$ but low communalities $(<0.50)$.

Factor 2--Plagioclase (log $\mathrm{CaO}$ and $\left.\log \mathrm{Na}_{2} \mathrm{O}\right)$--provenance.

Factor 3--Chlorite ( $\log \mathrm{MgO}, \log \mathrm{LOI}$, and $\log \mathrm{Ni}$ )--grain size.

Factor 4--Iron oxide minerals $\left(\log \mathrm{Fe}_{\mathrm{T}} \mathrm{O}_{3}, \log \mathrm{Ba}, \log \mathrm{Co}\right.$, and $\left.\log \mathrm{Cu}\right)$ vs $\mathrm{SiO}_{2}$--Placer concentration or mineralization. Log $\mathrm{Pb}$ has loading of 0.448 but low communality $(<0.50)$.

Factor 1 (micas) is nearly identical to factor 1 in rocks of the Salmon River Mountains. Values for $\mathrm{Al}_{2} \mathrm{O}_{3}, \mathrm{~K}_{2} \mathrm{O}, \log \mathrm{TiO}_{2}, \log \mathrm{Ga}$, and $\log \mathrm{Sc}$ show moderate to strong linear correlation (Fig. 12), as do those for $\log \mathrm{P}_{2} \mathrm{O}_{5}, \log \mathrm{B}, \log \mathrm{Cr}, \log \mathrm{V}$, and $\log \mathrm{Zr}$ (not shown). The correlation of $\mathrm{Al}_{2} \mathrm{O}_{3}$ with $\mathrm{K}_{2} \mathrm{O}$ and $\log \mathrm{TiO}_{2}$ almost certainly reflects variation in the abundance of mica(s). The trace elements $\mathrm{B}, \mathrm{Ga}, \mathrm{Sc}$, and $\mathrm{Zr}$ are commonly associated with the detrital (including clay) fraction of black shales (Vine and Tourtelot, 1970). Segregation by rock type along the line of best fit is not evident on most scattergrams, probably because argillites are poorly represented in the sample set. Diamictites are abundant, but their mica content and grain size are unknown and probably variable, as suggested by their wide range on scattergrams (Fig. 12). Correlations of $\mathrm{Al}_{2} \mathrm{O}_{3}$ with $\log \mathrm{TiO}_{2}$ are very high for diamictite and sandstone, but the line of best fit for diamictite follows a different trend from that of sandstone and all samples together (Fig. 12B). 
The loadings of $\log \mathrm{P}_{2} \mathrm{O}_{5}$ and $\log \mathrm{Zr}$ on factor 1 were also observed in the Salmon River Mountains, although the variance of these constituents was not accommodated well by the Salmon River Mountains factor solution (Table 6). The loading of $\log \mathrm{P}_{2} \mathrm{O}_{5}$ and $\log \mathrm{Zr}$ on factor 1 may be related to the presence of apatite and zircon inclusions in mica, but this possibility has not been researched.

Factor 2 (plagioclase) is the same as factor 4 in the Salmon River Mountains. A scattergram for $\log \mathrm{CaO}$ versus $\log \mathrm{Na}_{2} \mathrm{O}$, which have high loadings on factor 2 , shows a weak linear correlation of 0.446 (Fig. 13A). Eleven $\mathrm{Na}_{2} \mathrm{O}$ values that plot at $0.1 \mathrm{pct}(\log -1)$ have widely varying $\mathrm{CaO}$ contents, and many high values for $\log \mathrm{CaO}$ in siltite and sandstone of the Big Creek Formation (Fig. 13B) depart widely from the line of best fit, which weakens the correlation. Calcite and dolomite account for high $\mathrm{CaO}$ values in the Big Creek Formation (Tysdal, 2000b; G. A. Desborough, 2000, written commun.). Values for the diamictite, and for other rock types in the diamictite unit of the Apple Creek Formation, plot close to the line of best fit (Fig. 13B). The diamictite unit does not contain calcite. Values for Sr, which loaded on the factor for plagioclase in the Salmon River Mountains, were below the analytical limit of detection.

Mixing diagrams, involving oxides of factors 1 and 2 for rocks of the Lemhi Range, show results similar to those for the Salmon River Mountains (Fig. 14). Mixing lines for weight percent $\mathrm{SiO}_{2}, \mathrm{Al}_{2} \mathrm{O}_{3}$, and $\mathrm{K}_{2} \mathrm{O}$ follow the same trends as those for the Salmon River Mountains. For rocks of both ranges, mixtures consist of the same proportions of quartz, alkali feldspar, muscovite, plagioclase, and chlorite (with or without biotite). Only one line is required for mixtures of alkali feldspar and muscovite versus quartz and plagioclase in the Lemhi Range (Fig. 14C).

Factor 3 (chlorite) elements load with factor 1 (micas and chlorite) in rocks of the Salmon River Mountains. Linear correlations of factor 3 elements are weak to moderate, and the factor may be an artifact of the choice of the number of principal components preserved for rotation. High loadings of $\log \mathrm{MgO}, \log \mathrm{LOI}$, and $\log \mathrm{Ni}$ on factor 3 are consistent with magnesian chlorite. Chlorite is abundant in the diamictite unit of the Apple Creek Formation (Tietbohl, 1986). The factor has no known significance separate from factor 1 and is not further interpreted here.

Factor 4 (iron oxide minerals) includes high positive loadings of $\log \mathrm{Fe}_{\mathrm{T}} \mathrm{O}_{3}, \log \mathrm{Ba}, \log$ $\mathrm{Co}$ and $\log \mathrm{Cu}$ (Table 14). High loadings for $\log \mathrm{Co}$ and $\log \mathrm{Cu}$ would seem to suggest that factor 4 could be interpreted as mineralization. In general, however, the list of factor 4 oxides and trace elements for the Lemhi Range differs considerably from the mineralization factor for the Salmon River Mountains (Table 6). In fact, most correlations for factor 4 oxides and trace elements in Lemhi Range rocks are weak; $\log \mathrm{Fe}_{\mathrm{T}} \mathrm{O}_{3}$ is moderately correlated with $\log \mathrm{Ba}$ and, to a lesser extent, with $\log \mathrm{TiO}_{2}$ (Table 15; Fig. 15). In the Salmon River Mountains, Ba does not load on the mineralization factor; nor is Ba correlated with iron in mineralized rock at Iron Creek, in the Salmon River Mountains (Nash, 1989). In rocks of both the Salmon River Mountains and the Lemhi Range, $\mathrm{TiO}_{2}$ loads on factor 1 (micas or original grain size) in preference to any factor that could be interpreted as mineralization, and high $\mathrm{TiO}_{2}$ values would not seem indicative of mineralization. Finally, frequency distributions of $\mathrm{Co}$ and $\mathrm{Cu}$ in Lemhi Range rocks yield ambiguous evidence of mineralization: anomalous Co values are not present (Fig. 16A), but a few anomalous $\mathrm{Cu}$ values clearly are present (Fig. 16B).

The alternative interpretation of the linear correlations of $\log \mathrm{Fe}_{\mathrm{T}} \mathrm{O}_{3}$ with $\log \mathrm{Ba}$ and $\log$ $\mathrm{TiO}_{2}$, and the interpretation preferred here, is placer concentration during sedimentation. Both $\mathrm{Ba}$ and $\mathrm{TiO}_{2}$ may be concentrated in detrital iron oxides. The placer interpretation would also explain the high correlation of $\log \mathrm{Fe}_{\mathrm{T}} \mathrm{O}_{3}$ with $\log \mathrm{TiO}_{2}$ in sandstone (Fig. 15B), expecially sandstone of nearshore origin (Tysdal, 2000b) in the Big Creek Formation (Fig. 15C). 

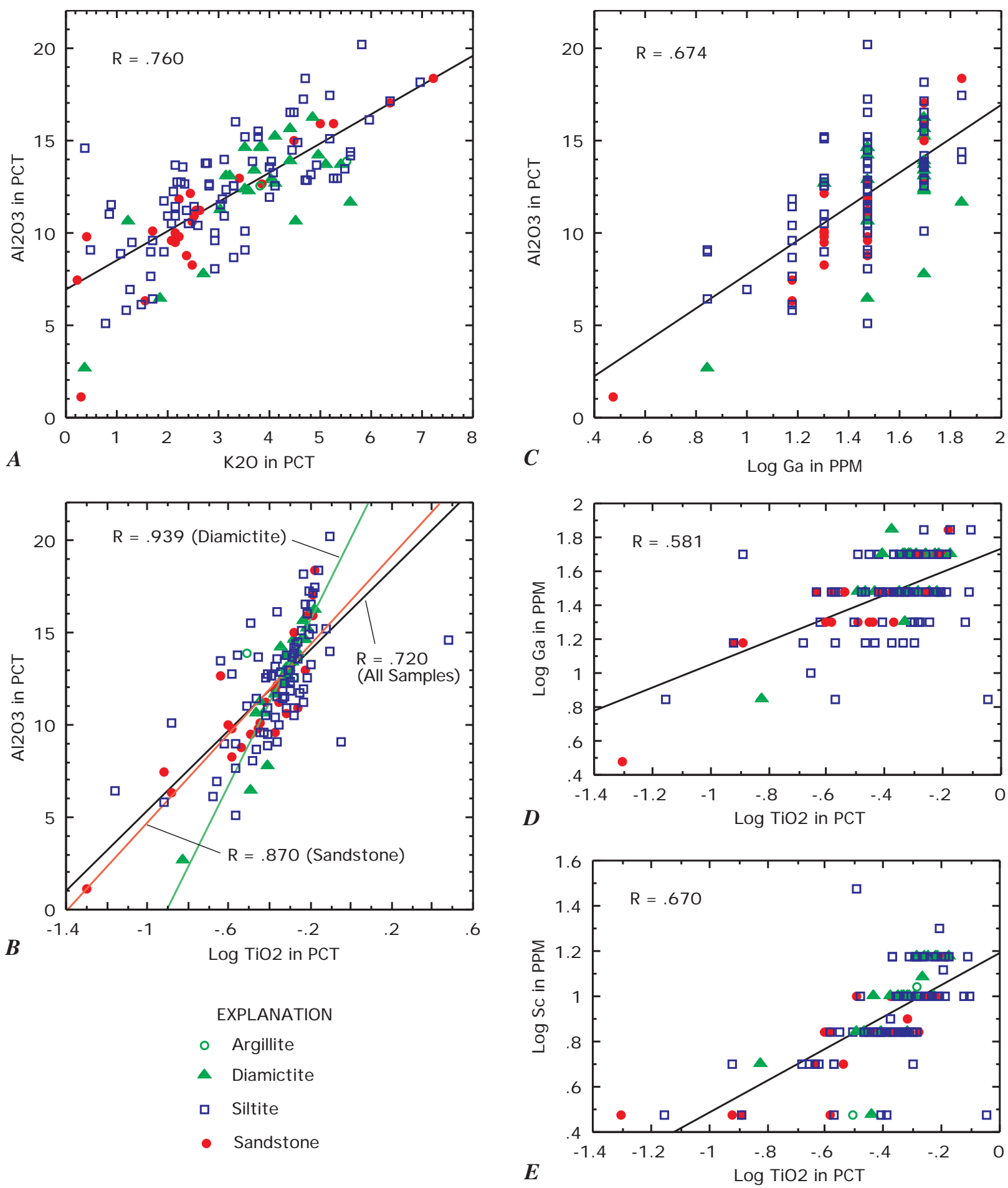

Figure 12.--Scattergrams of factor 1 oxides and trace elements for the Big Creek and Apple Creek Formations, Lemhi Range: A) $\mathrm{Al}_{2} \mathrm{O}_{3}$ versus $\mathrm{K}_{2} \mathrm{O}$, B) $\mathrm{Al}_{2} \mathrm{O}_{3}$ versus $\log \mathrm{TiO}_{2}$, C) $\mathrm{Al}_{2} \mathrm{O}_{3}$ versus $\left.\log \mathrm{Ga}, \mathrm{D}\right) \log \mathrm{Ga}$ versus $\log \mathrm{TiO}_{2}$, and $\left.\mathrm{E}\right) \log \mathrm{Sc}$ versus $\log \mathrm{TiO}_{2}$. R, correlation coefficient; lines are least-squares fit. PCT, weight percent; PPM, parts per million. 


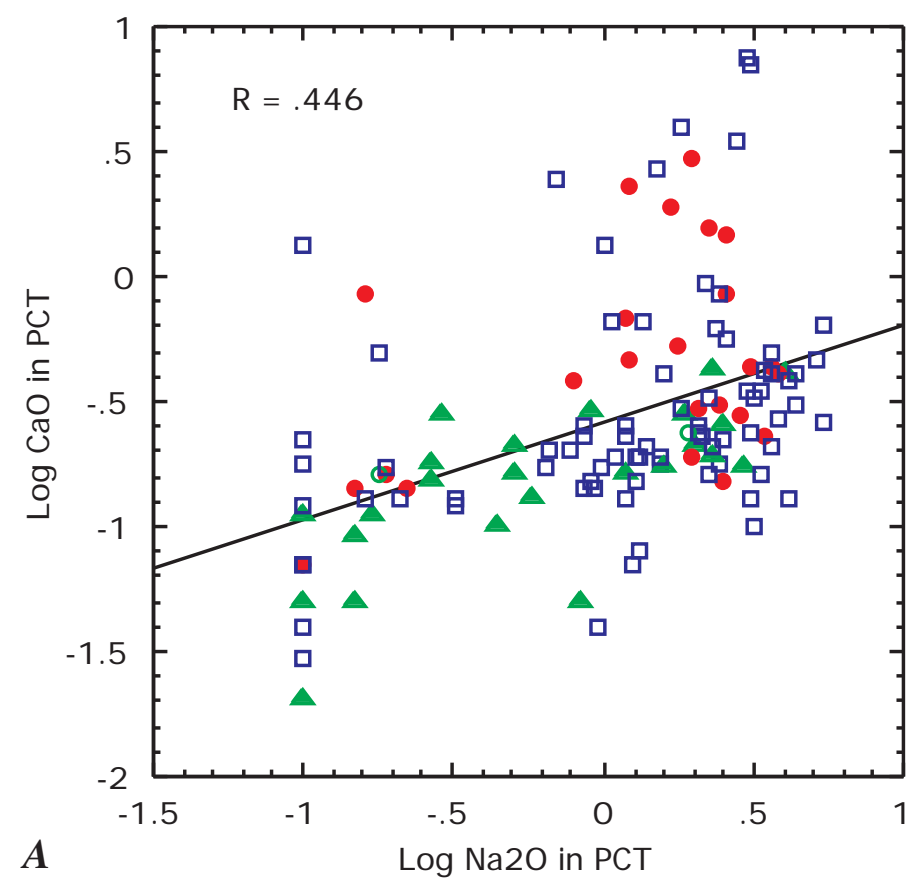

EXPLANATION
- Argillite
- Diamictite
- Siltite
- Sandstone

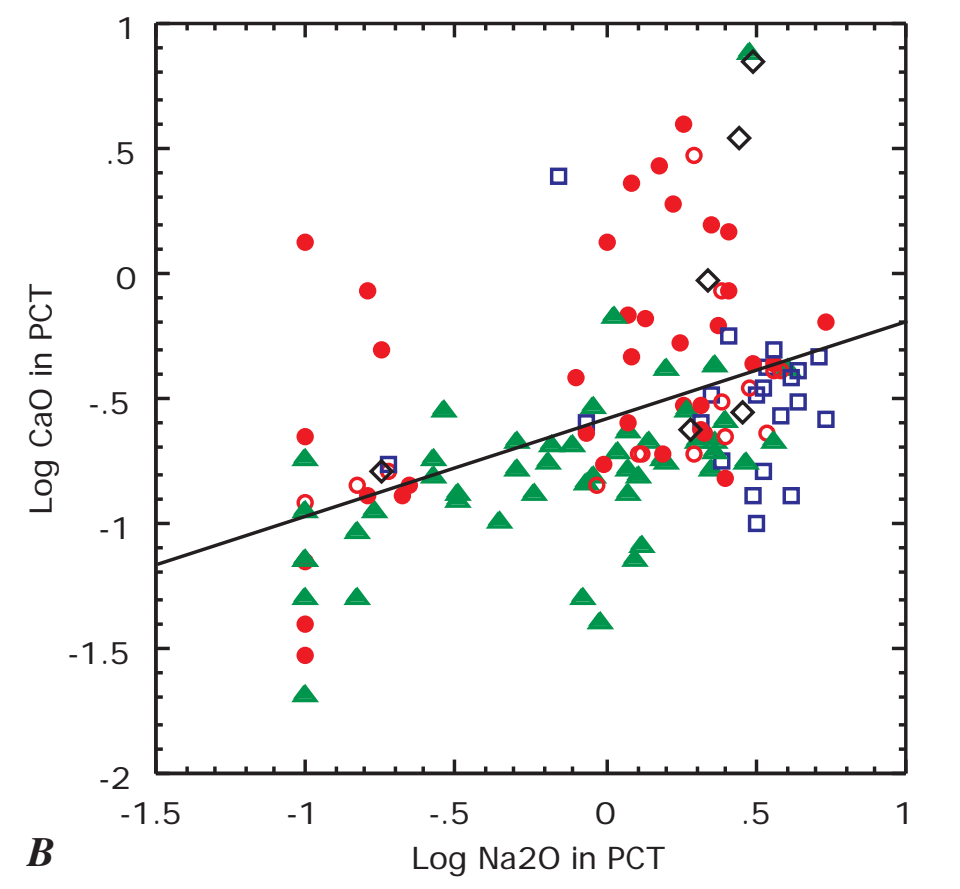

\section{EXPLANATION}

Apple Creek Formation

ㅁ Coarse siltite unit

- Diamictite unit

- Fine siltite unit

$\diamond \quad$ Yellow Lake unit

- Big Creek Formation

Figure 13.--Scattergrams of factor 2 oxides $\left(\log \mathrm{CaO}\right.$ and $\left.\log \mathrm{Na}_{2} \mathrm{O}\right)$, Big Creek and Apple Creek Formations, Lemhi Range: A) classified by rock type (grain size), B) classified by formation. $\mathrm{CaO}$ in $\mathrm{Big}$ Creek Formation partly in calcite and dolomite (G. A. Desborough, 2000, written commun.). R, correlation coefficient; line is least-squares fit. PCT, weight percent. 

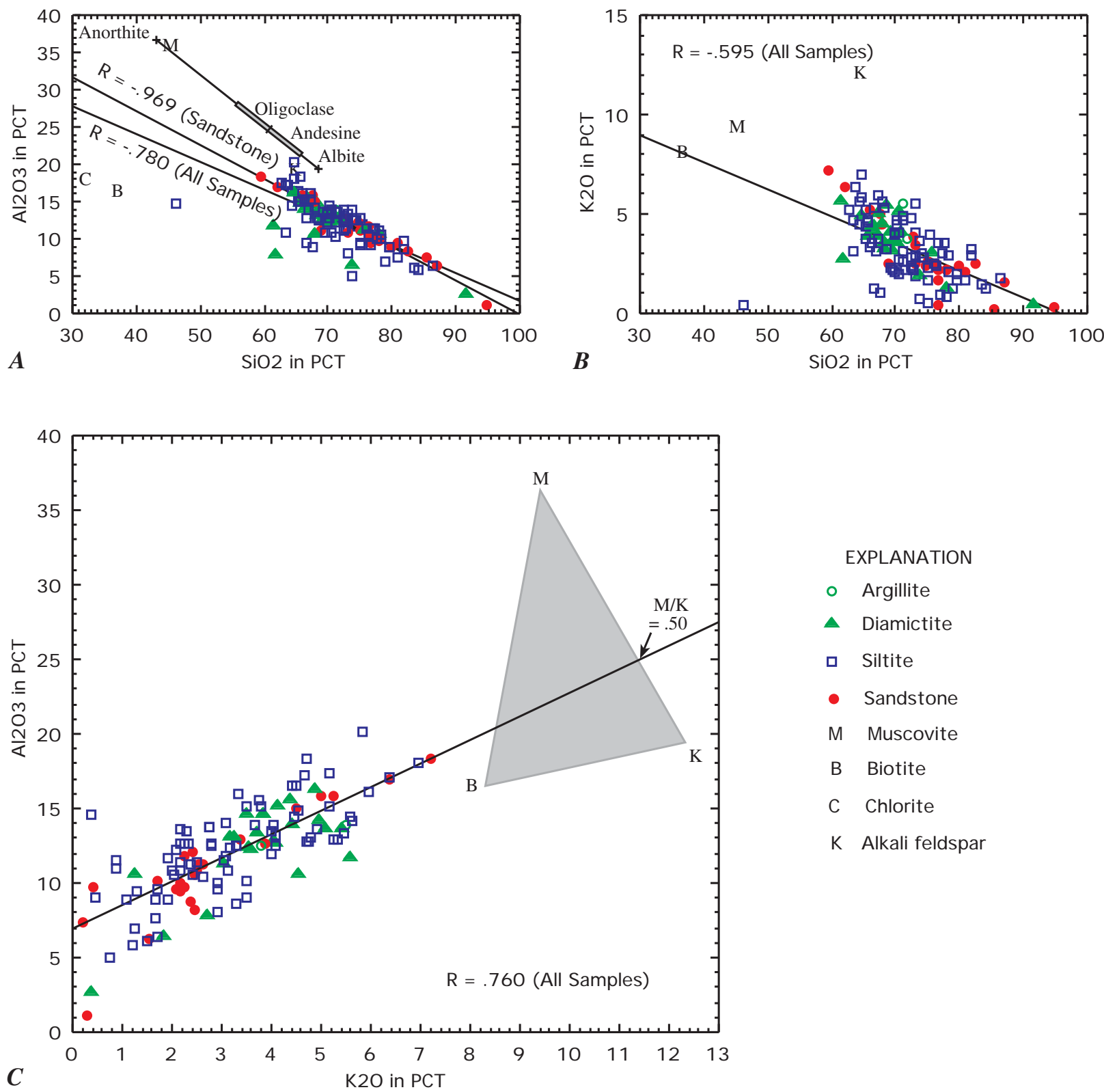

Figure 14.--Scattergrams illustrating mixtures of quartz $\left(\mathrm{SiO}_{2}\right)$, muscovite, biotite, alkali feldspar and plagioclase to produce sandstone, siltite, argillite, and diamictite of the Big Creek and Apple Creek Formations, Lemhi Range. A) $\mathrm{Al}_{2} \mathrm{O}_{3}$ versus $\left.\mathrm{SiO}_{2}, \mathrm{~B}\right) \mathrm{K}_{2} \mathrm{O}$ versus $\mathrm{SiO}_{2}$, and C) $\mathrm{Al}_{2} \mathrm{O}_{3}$ versus $\mathrm{K}_{2} \mathrm{O}$. R, correlation coefficient; lines are least-squares fit. All oxides in weight percent (PCT). Values for muscovite, chlorite, albite, and anorthite are ideal compositions from Dana (1932); values for biotite, alkali feldspar, plagioclase, and andesine are averages of selected analyses from Deer and others $(1963,1966)$. Shaded triangle M-B$\mathrm{K}$ is approximate composition range for mixtures of muscovite-biotite-alkali feldspar. 
Table 15.--Linear correlation coefficients for factor 4 elements and $\log \mathrm{TiO}_{2}$, Big Creek and Apple Creek Formations, Lemhi Range, Idaho. Coefficients computed from 113 values; 15 cases were omitted due to missing values. $\mathrm{Fe}_{\mathrm{T}} \mathrm{O}_{3}$, total iron as $\mathrm{Fe}_{2} \mathrm{O}_{3}$. Bold type, $\mathrm{R}=/>0.50$.

\begin{tabular}{llllll}
\hline & $\log \mathrm{Ba}$ & $\log \mathrm{Co}$ & $\log \mathrm{Cu}$ & $\log \mathrm{Pb}$ & $\log \mathrm{TiO}_{2}$ \\
\hline $\log \mathrm{Fe}_{\mathrm{T}} \mathrm{O}_{3}$ & $\mathbf{. 6 0 8}$ & .339 & .422 & .183 &. $\mathbf{5 3 7}$ \\
$\operatorname{Log~Ba}$ & & .267 & .343 & .137 & .332 \\
$\log \mathrm{Co}$ & & & .337 & .050 & .184 \\
$\log \mathrm{Cu}$ & & & & .235 & .150 \\
$\log \mathrm{Pb}$ & & & & & .143 \\
\hline
\end{tabular}
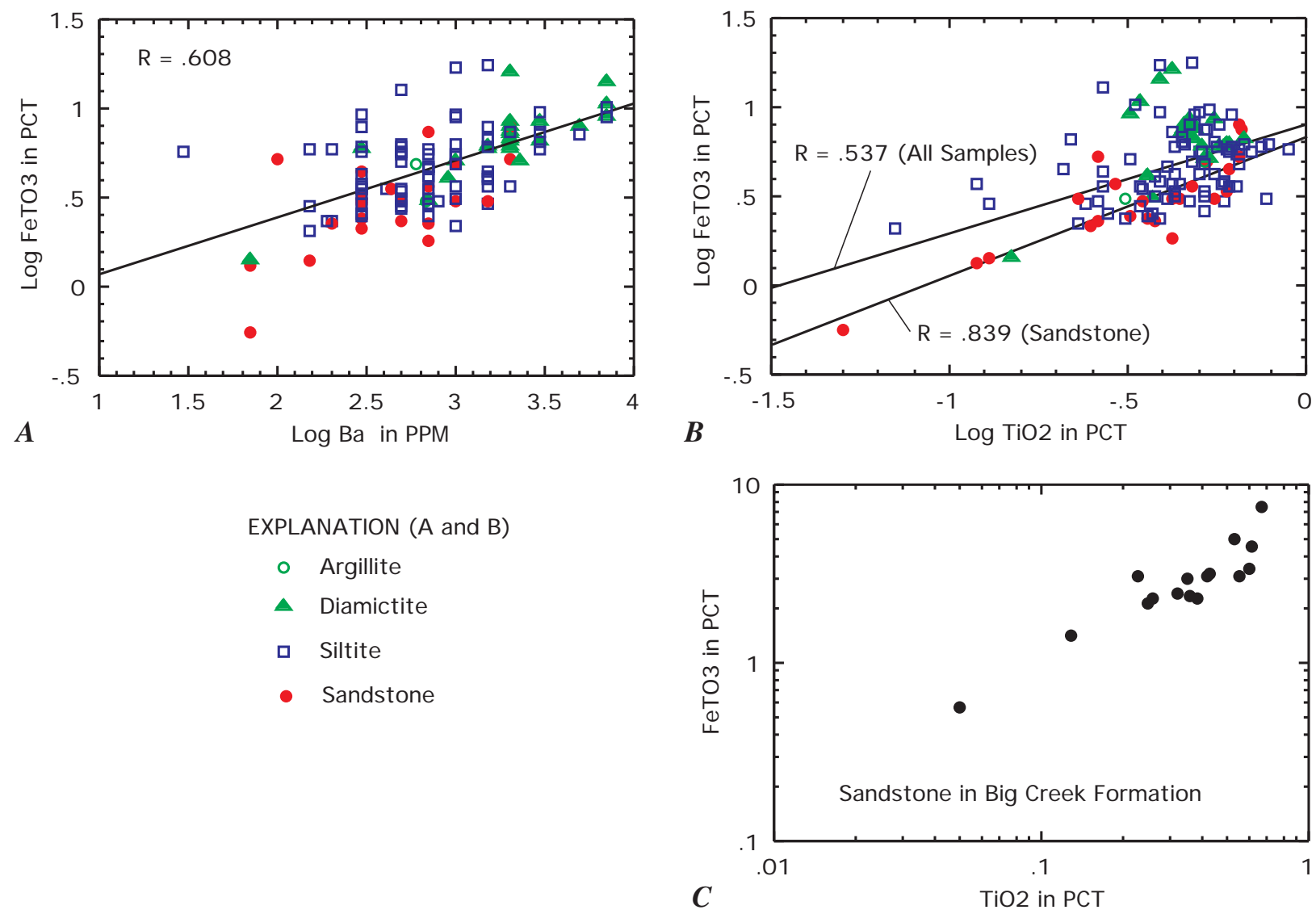

Figure 15.--Scattergrams for factor 4 oxides and elements, and $\mathrm{TiO}_{2}$, Big Creek and Apple Creek Formations, Lemhi Range: A) $\log \mathrm{Fe}_{\mathrm{T}} \mathrm{O}_{3}$ (total iron as $\mathrm{Fe}_{2} \mathrm{O}_{3}$ ) versus $\log \mathrm{Ba}$, both of which have high loadings on factor $4, \mathrm{~B}$ ) $\log \mathrm{Fe}_{\mathrm{T}} \mathrm{O}_{3}$ versus $\log \mathrm{TiO}_{2}$, and $\mathrm{C}$ ) $\mathrm{Fe}_{\mathrm{T}} \mathrm{O}_{3}$ versus $\mathrm{TiO}_{2}$ in sandstone of the Big Creek Formation (note log scales). $\mathrm{Log}_{\mathrm{TiO}_{2}}$ does not load on factor 4, but has a moderate linear correlation with $\mathrm{Fe}_{\mathrm{T}} \mathrm{O}_{3}$, and a high correlation with $\mathrm{Fe}_{\mathrm{T}} \mathrm{O}_{3}$ in sandstone. $R$, correlation coefficient; lines are least-squares fit. $\mathrm{Fe}_{\mathrm{T}} \mathrm{O}_{3}$, total iron as $\mathrm{Fe}_{2} \mathrm{O}_{3}$. PCT, weight percent. 

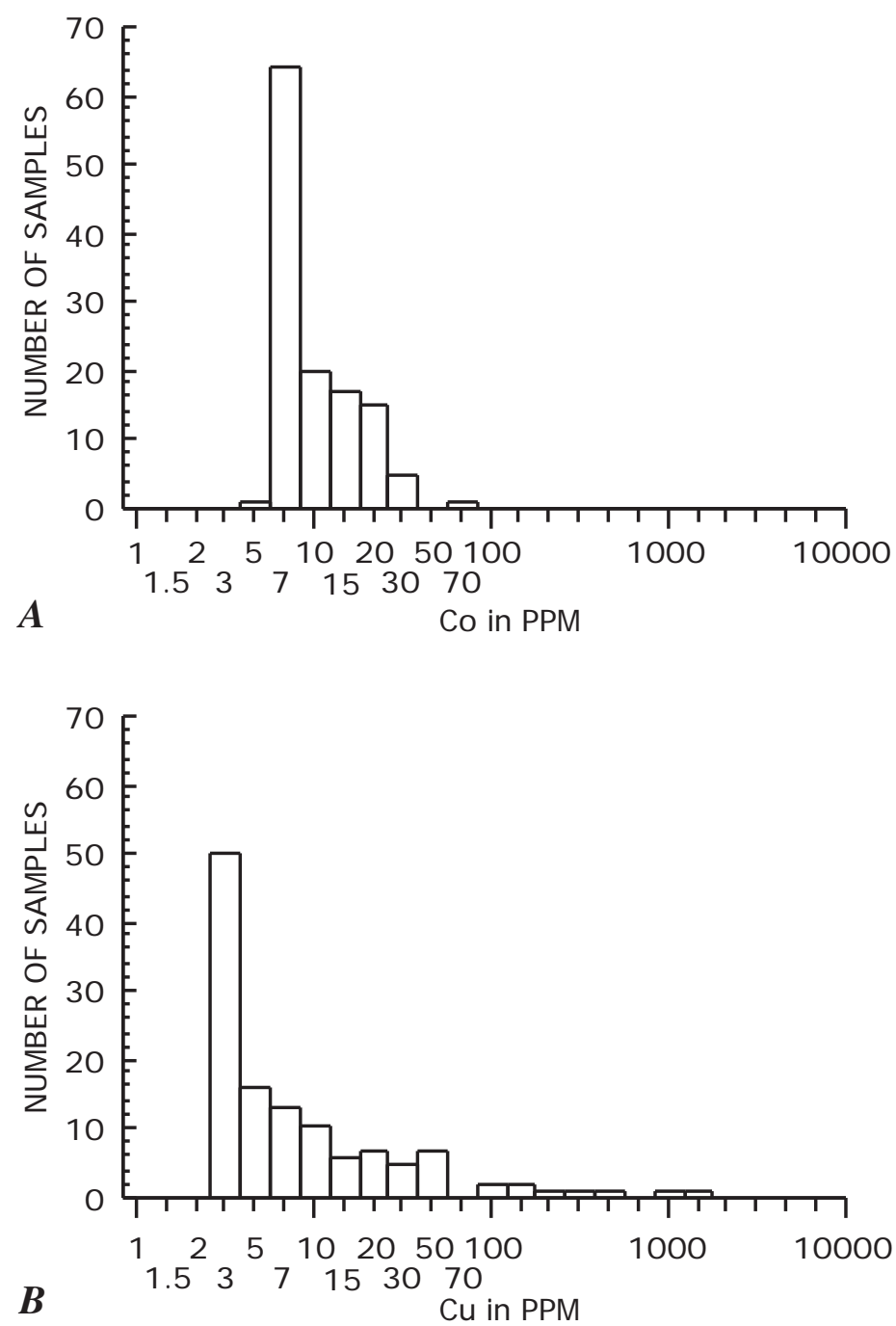

Figure 16.--Frequency distributions for A) $\mathrm{Co}$ and B) $\mathrm{Cu}$ in the Big Creek and Apple Creek Formations, Lemhi Range. Midpoints of classes follow the geometric series 1, 1.5, 2, 3, 5, 7, 10, etc. PPM, parts per million.

\section{Stratigraphic Variation}

Stratigraphic variation in the Lemhi Range was examined by analysis of variance of factor scores for siltites in three stratigraphic units, here termed "formations" (Table 16). The analysis was restricted by the distribution of samples (Table 1). Samples of sandstone and argillite are not well represented in many formations, and diamictite is restricted to the diamictite unit (Yad) of the Apple Creek Formation. By holding rock type constant (to siltite), possible effects of grain size on composition are (hopefully) controlled. For siltites, scores for factors 2 (plagioclase) and 4 (iron oxide minerals) show significant variation among the three stratigraphic units (Table 16). 
Table 16.--Analysis of variance of factor scores for 59 siltite samples from the Big Creek and Apple Creek Formations, Lemhi Range. Yac, coarse siltite unit of Apple Creek Formation; Yad, diamictite unit of Apple Creek Formation; and Yb, the Big Creek Formation. F-value, mean square of effect (Formation) divided by residual mean square; P-value, probability of no significant difference among formations; $\mathbf{S}$, significant at $<0.05$ level.

Analysis of variance for factor 1 scores among formations

\begin{tabular}{llllll}
\hline & $\begin{array}{l}\text { Degrees of } \\
\text { Freedom }\end{array}$ & $\begin{array}{l}\text { Sum of } \\
\text { Squares }\end{array}$ & $\begin{array}{l}\text { Mean } \\
\text { Square }\end{array}$ & F-Value & P-Value \\
\hline Formation & 2 & 4.669 & 2.335 & 2.578 & .0849 \\
Residual & 56 & 50.721 & .906 & & \\
\hline
\end{tabular}

Analysis of variance for factor 2 scores among formations

\begin{tabular}{llllll}
\hline & $\begin{array}{l}\text { Degrees of } \\
\text { Freedom }\end{array}$ & $\begin{array}{l}\text { Sum of } \\
\text { Squares }\end{array}$ & $\begin{array}{l}\text { Mean } \\
\text { Square }\end{array}$ & F-Value & P-Value \\
\hline Formation & 2 & 19.886 & 9.943 & 13.846 & $<.0001 \mathbf{~ S}$ \\
Residual & 56 & 40.213 & .718 & & \\
\hline
\end{tabular}

Analysis of variance for factor 3 scores among formations

\begin{tabular}{llllll}
\hline & $\begin{array}{l}\text { Degrees of } \\
\text { Freedom }\end{array}$ & $\begin{array}{l}\text { Sum of } \\
\text { Squares }\end{array}$ & $\begin{array}{l}\text { Mean } \\
\text { Square }\end{array}$ & F-Value & P-Value \\
\hline Formation & 2 & .763 & .381 & .371 & .6916 \\
Residual & 56 & 57.553 & 1.028 & & \\
\hline
\end{tabular}

Analysis of variance for factor 4 scores among formations

\begin{tabular}{llllll}
\hline & $\begin{array}{l}\text { Degrees of } \\
\text { Freedom }\end{array}$ & $\begin{array}{l}\text { Sum of } \\
\text { Squares }\end{array}$ & $\begin{array}{l}\text { Mean } \\
\text { Square }\end{array}$ & F-Value & P-Value \\
\hline Formation & 2 & 15.136 & 7.568 & 12.490 & $<.0001 \mathbf{S}$ \\
Residual & 56 & 33.933 & .606 & & \\
\hline
\end{tabular}

Differences among stratigraphic units were further investigated by tests for differences among mean scores for factors 2 and 4 (Tables 17 and 18). The test used for differences among means is Fisher's PLSD (Protected Least Significant Difference) method (discussed by SAS Institute Inc., 1998). The PLSD test is relevant only if the analysis of variance reveals a significant difference among formations. The test assumes equal sample numbers and homogenous variances among stratigraphic units; for the most part, these criteria were met by the example under discussion. The analysis of variance for each factor is repeated in the tables for convenient reference.

An analysis of variance and tests for differences among mean values for stratigraphic units were also conducted for selected oxides and trace elements represented by high loadings in factors 2 and 4 (Tables 17 and 18). Analysis of individual element values sidesteps questions about factor interpretation, and tests for differences among means permit identification of oxides and elements that may be used to distinguish formations. 
Table 17.--Analysis of variance and Fisher's PLSD test for differences among mean values for factor 2 scores, $\log \mathrm{CaO}$, and $\log \mathrm{Na}_{2} \mathrm{O}$ in siltite samples from the Big Creek and Apple Creek Formations, Lemhi Range. Yac, coarse siltite unit of Apple Creek Formation; Yad, diamictite unit of Apple Creek Formation; Yb, Big Creek Formation. Number of samples for factor 2 scores, 59; for $\log \mathrm{CaO}$ and $\log \mathrm{Na}_{2} \mathrm{O}, 66$. F-value, mean square of effect (Formation) divided by residual mean square; P-value, probability of no difference among formations; $\mathbf{S}$, significant at $<0.05$ level.

Analysis of variance for factor 2 scores among formations

\begin{tabular}{llllll} 
& $\begin{array}{l}\text { Degrees of } \\
\text { Freedom }\end{array}$ & $\begin{array}{l}\text { Sum of } \\
\text { Squares }\end{array}$ & $\begin{array}{l}\text { Mean } \\
\text { Square }\end{array}$ & F-Value & P-Value \\
\hline Formation & 2 & 19.886 & 9.943 & 13.846 & $<.0001 \mathbf{S}$ \\
Residual & 56 & 40.213 & .718 & & \\
\hline
\end{tabular}

Mean values of factor 2 scores for formations

\begin{tabular}{lllll}
\hline Formation & $\begin{array}{l}\text { Number of } \\
\text { Samples }\end{array}$ & Mean & $\begin{array}{l}\text { Standard } \\
\text { Deviation }\end{array}$ & Standard Error \\
\hline Yac & 21 & .766 & .662 & .142 \\
Yad & 22 & -.505 & .675 & .144 \\
$\mathrm{Yb}$ & 16 & -.346 & 1.207 & .302 \\
\hline
\end{tabular}

Fisher's PLSD test for differences in mean values of factor 2 scores among formations

\begin{tabular}{llll}
\hline Formation Pair & $\begin{array}{l}\text { Mean } \\
\text { Difference }\end{array}$ & $\begin{array}{l}\text { Critical } \\
\text { Difference }\end{array}$ & P-Value \\
\hline Yac, Yad & 1.273 & .518 & $<.0001 \mathbf{S}$ \\
Yac, Yb & 1.112 & .563 & $.0002 \mathbf{S}$ \\
Yad, Yb & -.161 & .558 & .5949 \\
\hline
\end{tabular}

Analysis of variance for $\log \mathrm{CaO}$ among formations

\begin{tabular}{llllll}
\hline & $\begin{array}{l}\text { Degrees of } \\
\text { Freedom }\end{array}$ & $\begin{array}{l}\text { Sum of } \\
\text { Squares }\end{array}$ & $\begin{array}{l}\text { Mean } \\
\text { Square }\end{array}$ & F-Value & P-Value \\
\hline Formation & 2 & .978 & .489 & 2.673 & .0769 \\
Residual & 63 & 11.530 & .183 & & \\
\hline
\end{tabular}

Mean values of $\log \mathrm{CaO}$ for formations

\begin{tabular}{lllll}
\hline Formation & $\begin{array}{l}\text { Number of } \\
\text { Samples }\end{array}$ & Mean & $\begin{array}{l}\text { Standard } \\
\text { Deviation }\end{array}$ & Standard Error \\
\hline Yac & 21 & -.526 & .295 & .064 \\
Yad & 25 & -.748 & .421 & .084 \\
Yb & 20 & -.473 & .539 & .121 \\
\hline
\end{tabular}

Fisher's PLSD test for differences in mean values of log $\mathrm{CaO}$ among formations

\begin{tabular}{llll}
\hline Formation Pair & $\begin{array}{l}\text { Mean } \\
\text { Difference }\end{array}$ & $\begin{array}{l}\text { Critical } \\
\text { Difference }\end{array}$ & P-Value \\
\hline
\end{tabular}




\begin{tabular}{llll} 
Yac, Yad & .222 & .253 & .0849 \\
Yac, Yb & -.053 & .267 & .6956 \\
Yad, Yb & -.274 & .256 & $.0355 \mathbf{S}$ \\
\hline
\end{tabular}

Analysis of variance for $\log \mathrm{Na}_{2} \mathrm{O}$ among formations

\begin{tabular}{llllll}
\hline & $\begin{array}{l}\text { Degrees of } \\
\text { Freedom }\end{array}$ & $\begin{array}{l}\text { Sum of } \\
\text { Squares }\end{array}$ & $\begin{array}{l}\text { Mean } \\
\text { Square }\end{array}$ & F-Value & P-Value \\
\hline Formation & 2 & 4.155 & 2.077 & 10.131 & $<.0002 \mathbf{S}$ \\
Residual & 63 & 12.918 & .205 & & \\
\hline
\end{tabular}

Mean values of $\log \mathrm{Na}_{2} \mathrm{O}$ for formations

\begin{tabular}{lllll}
\hline Formation & $\begin{array}{l}\text { Number of } \\
\text { Samples }\end{array}$ & Mean & $\begin{array}{l}\text { Standard } \\
\text { Deviation }\end{array}$ & Standard Error \\
\hline Yac & 21 & .416 & .342 & .075 \\
Yad & 25 & -.070 & .428 & .086 \\
Yb & 20 & -.172 & .570 & .127 \\
\hline
\end{tabular}

Fisher's PLSD test for differences in mean values of $\log \mathrm{Na}_{2} \mathrm{O}$ among formations

\begin{tabular}{llll}
\hline Formation Pair & $\begin{array}{l}\text { Mean } \\
\text { Difference }\end{array}$ & $\begin{array}{l}\text { Critical } \\
\text { Difference }\end{array}$ & P-Value \\
& .486 & .268 & $.0006 \mathbf{S}$ \\
Yac, Yad & .588 & .283 & $<.0001 \mathbf{S}$ \\
Yac, Yb & .102 & .271 & .4562 \\
Yad, Yb & &
\end{tabular}


Table 18.--Analysis of variance and Fisher's PLSD test for differences among mean values for factor 4 scores, $\log \mathrm{Fe}_{\mathrm{T}} \mathrm{O}_{3}$, and $\log \mathrm{Ba}$ in siltite samples in the Big Creek and Apple Creek Formations, Lemhi Range. Yac, coarse siltite unit of Apple Creek Formation; Yad, diamictite unit of Apple Creek Formation; and Yb, Big Creek Formation. Number of samples for factor 4 scores, 59; for $\log \mathrm{Fe}_{\mathrm{T}} \mathrm{O}_{3}$, 66; for $\log \mathrm{Ba}, 61$. F-value, mean square of effect (Formation) divided by residual mean square; P-value, probability of no significant difference among formations; $\mathbf{S}$, significant at $<0.05$ level.

Analysis of variance for factor 4 scores among formations

\begin{tabular}{llllll}
\hline & $\begin{array}{l}\text { Degrees of } \\
\text { Freedom }\end{array}$ & $\begin{array}{l}\text { Sum of } \\
\text { Squares }\end{array}$ & $\begin{array}{l}\text { Mean } \\
\text { Square }\end{array}$ & F-Value & P-Value \\
\hline Formation & 2 & 15.136 & 7.568 & 12.490 & $<.0001 \mathbf{S}$ \\
Residual & 56 & 33.933 & .606 & & \\
\hline
\end{tabular}

Mean values of factor 4 scores for formations

\begin{tabular}{lllll}
\hline Formation & $\begin{array}{l}\text { Number of } \\
\text { Samples }\end{array}$ & Mean & $\begin{array}{l}\text { Standard } \\
\text { Deviation }\end{array}$ & Standard Error \\
\hline Yac & 21 & .671 & .986 & .215 \\
Yad & 22 & .496 & .580 & .124 \\
Yb & 16 & -.545 & .704 & .176 \\
\hline
\end{tabular}

Fisher's PLSD test for differences in mean values of factor 4 scores among formations

\begin{tabular}{llll}
\hline Formation Pair & $\begin{array}{l}\text { Mean } \\
\text { Difference }\end{array}$ & $\begin{array}{l}\text { Critical } \\
\text { Difference }\end{array}$ & P-Value \\
\hline Yac, Yad & .175 & .476 & .4643 \\
Yac, Yb & 1.216 & .517 & $<.0001 \mathbf{S}$ \\
Yad, Yb & 1.041 & .512 & $.0001 \mathbf{S}$ \\
\hline
\end{tabular}

Analysis of variance for $\log \mathrm{Fe}_{\mathrm{T}} \mathrm{O}_{3}$ values among formations

\begin{tabular}{llllll}
\hline & $\begin{array}{l}\text { Degrees of } \\
\text { Freedom }\end{array}$ & $\begin{array}{l}\text { Sum of } \\
\text { Squares }\end{array}$ & $\begin{array}{l}\text { Mean } \\
\text { Square }\end{array}$ & F-Value & P-Value \\
\hline Formation & 2 & .946 & .473 & 14.045 & $<.0001 \mathbf{S}$ \\
Residual & 63 & 2.122 & .034 & & \\
\hline
\end{tabular}

Mean values of $\log \mathrm{Fe}_{\mathrm{T}} \mathrm{O}_{3}$ for formations

\begin{tabular}{lllll}
\hline Formation & $\begin{array}{l}\text { Number of } \\
\text { Samples }\end{array}$ & Mean & $\begin{array}{l}\text { Standard } \\
\text { Deviation }\end{array}$ & Standard Error \\
\hline Yac & 21 & .640 & .212 & .046 \\
Yad & 25 & .850 & .186 & .037 \\
Yb & 20 & .576 & .145 & .032 \\
\hline
\end{tabular}

Fisher's PLSD test for differences in mean values of $\log \mathrm{Fe}_{\mathrm{T}} \mathrm{O}_{3}$ among formations

\begin{tabular}{llll}
\hline Formation Pair & $\begin{array}{l}\text { Mean } \\
\text { Difference }\end{array}$ & $\begin{array}{l}\text { Critical } \\
\text { Difference }\end{array}$ & P-Value \\
\hline Yac, Yad & -.210 & .100 & $.0003 \mathbf{S}$ \\
\hline
\end{tabular}




\begin{tabular}{llll}
\hline Yac, Yb & .064 & .115 & .2656 \\
Yad, Yb & .274 & .110 & $<.0001 \mathbf{S}$ \\
\hline
\end{tabular}

Analysis of variance for $\log \mathrm{Ba}$ values among formations

\begin{tabular}{llllll}
\hline & $\begin{array}{l}\text { Degrees of } \\
\text { Freedom }\end{array}$ & $\begin{array}{l}\text { Sum of } \\
\text { Squares }\end{array}$ & $\begin{array}{l}\text { Mean } \\
\text { Square }\end{array}$ & F-Value & P-Value \\
\hline Formation & 2 & 1.896 & .948 & 9.015 & $.0004 \mathbf{S}$ \\
Residual & 58 & 6.099 & .105 & & \\
\hline
\end{tabular}

Mean values of $\log \mathrm{Ba}$ for formations

\begin{tabular}{lllll}
\hline Formation & $\begin{array}{l}\text { Number of } \\
\text { Samples }\end{array}$ & Mean & $\begin{array}{l}\text { Standard } \\
\text { Deviation }\end{array}$ & Standard Error \\
\hline Yac & 21 & 2.832 & .225 & .049 \\
Yad & 24 & 3.144 & .426 & .087 \\
Yb & 16 & 2.738 & .247 & .062 \\
\hline
\end{tabular}

Fisher's PLSD test for differences in mean values of log Ba among formations

\begin{tabular}{llll}
\hline Formation Pair & $\begin{array}{l}\text { Mean } \\
\text { Difference }\end{array}$ & $\begin{array}{l}\text { Critical } \\
\text { Difference }\end{array}$ & P-Value \\
\hline Yac, Yad & -.312 & .194 & $.0021 \mathbf{S}$ \\
Yac, Yb & .094 & .215 & .3846 \\
Yad, Yb & .407 & .210 & $.0003 \mathbf{S}$ \\
\hline
\end{tabular}


In addition to scores for factors 2 and 4, analysis of variance revealed differences among stratigraphic units for values of $\log \mathrm{Na}_{2} \mathrm{O}, \log \mathrm{Fe}_{\mathrm{T}} \mathrm{O}_{3}$, and $\log \mathrm{Ba}$ (Tables 17 and 18). No significant difference was found for $\log \mathrm{CaO}$ at the 0.05 level, but a slight relaxation of the 0.05 standard would permit inclusion of $\log \mathrm{CaO}$ among oxides showing differences among stratigraphic units. Thus, plots of $\mathrm{CaO}, \mathrm{Na}_{2} \mathrm{O}, \mathrm{Fe}_{\mathrm{T}} \mathrm{O}_{3}$, and $\mathrm{Ba}$ values for siltite of each formation (Fig. 17) should be useful in discriminating between formations. The plots are only valid for the rock type siltite in the coarse siltite unit of the Apple Creek Formation, the diamictite unit of the Apple Creek Formation, and the Big Creek Formation. Available data are insufficient to test for differences among other stratigraphic units or rock types other than siltite.

The stratigraphic variation in $\log \mathrm{Na}_{2} \mathrm{O}$ in siltite is interpreted as variation in provenance during deposition of the lower part of the Big Creek and Apple Creek Formations. The amount of plagioclase, as indicated by $\mathrm{Na}_{2} \mathrm{O}$, reflects the degree of weathering before and during transit to the site of final deposition. Relative to quartz and alkali feldspar, plagioclase is less stable during weathering. Sodium is most abundant in the coarse siltite unit of the Apple Creek Formation (Fig. 17). The high content of $\mathrm{Na}_{2} \mathrm{O}$ in the coarse siltite unit indicates fresh, plagioclase-rich detritus from the source area.

Because calcite and dolomite account for high $\mathrm{CaO}$ values in the Big Creek Formation (Tysdal, 2000b; G. A. Desborough, 2000, written commun.), $\mathrm{CaO}$ cannot be used as an indicator of plagioclase for that formation.

Iron oxide and barium, which are correlated (Table 15; Fig. 15), probably both represent iron oxide minerals. Among siltites, both $\mathrm{Ba}$ and $\mathrm{Fe}_{\mathrm{T}} \mathrm{O}_{3}$ are most abundant in the diamictite unit of the Apple Creek Formation, suggesting that relatively less destruction of iron oxides during weathering and transport than was the case for other units. Iron oxides are susceptible to destruction by weathering in the source area, by soil formation on alluvium, and by diagenesis. In sandy rocks, they can be concentrated by hydraulic processes. The action of hydraulic processes during deposition of sandstones is evident in the high correlation of $\mathrm{Fe}_{\mathrm{T}} \mathrm{O}_{3}$ and $\mathrm{TiO}_{2}$ in sandstone of the Big Creek Formation (Fig. 15). 

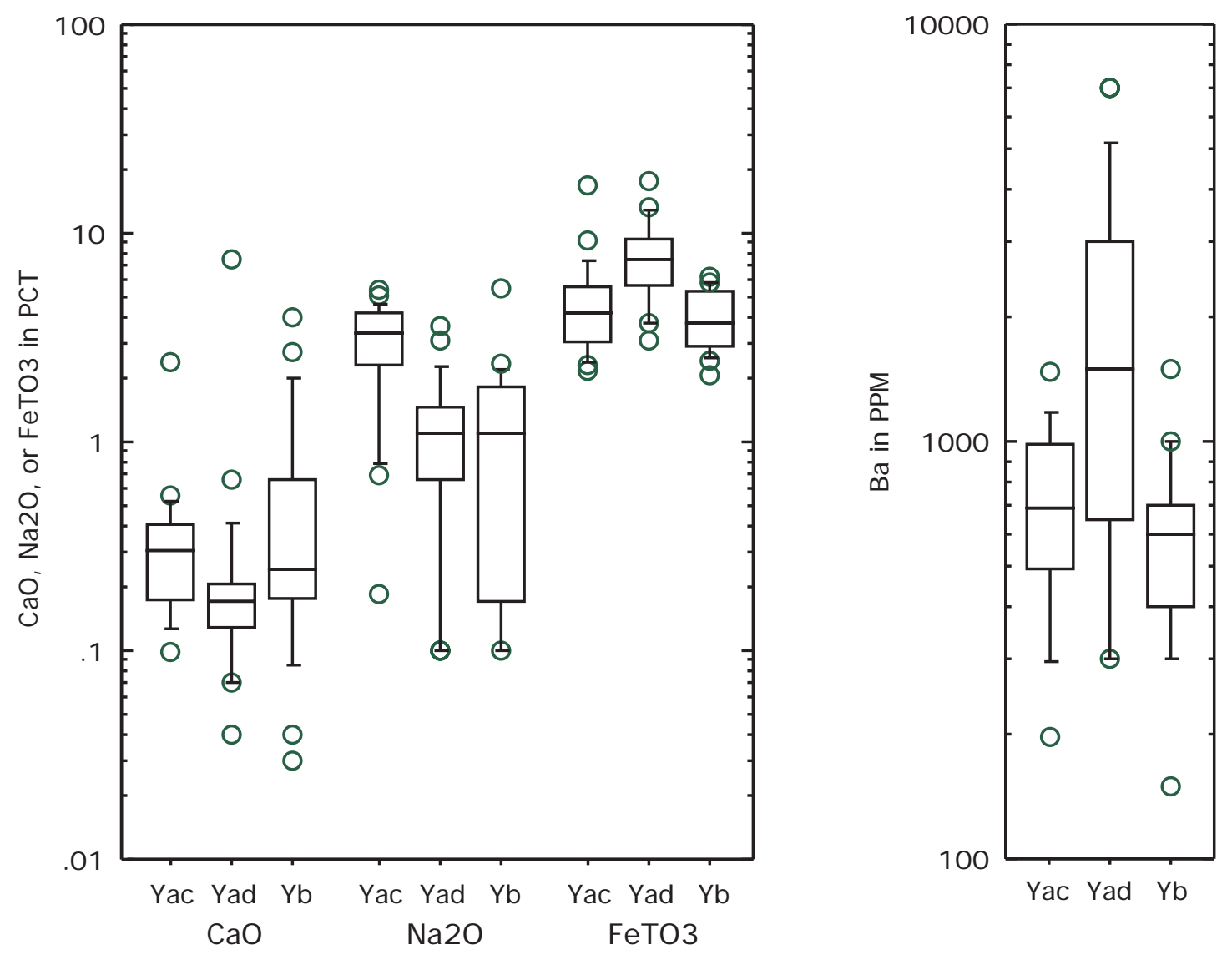

EXPLANATION

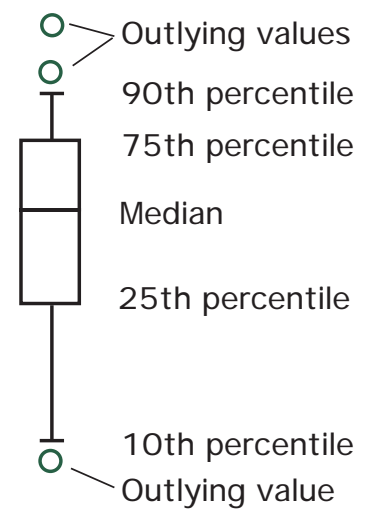

Figure 17.--Box plots showing composition of siltite, showing median and percentile $\left(10^{\text {th }}, 25^{\text {th }}\right.$, $75^{\text {th }}$, and $90^{\text {th }}$ ) values, and outlying values for $\mathrm{CaO}, \mathrm{Na}_{2} \mathrm{O}$, and $\mathrm{Fe}_{\mathrm{T}} \mathrm{O}_{3}$ in percent (PCT) and $\mathrm{Ba}$ in parts per million (PPM), Lemhi Range. Formations are: Yac, coarse siltite unit of Apple Creek Formation; Yad, diamictite unit of Apple Creek Formation; and Yb, Big Creek Formation. $\mathrm{Fe}_{\mathrm{T}} \mathrm{O}_{3}$, total iron as $\mathrm{Fe}_{2} \mathrm{O}_{3}$.

\section{COMPARISON OF ROCK COMPOSITIONS: SALMON RIVER MOUNTAINS VERSUS THE LEMHI RANGE}

Direct comparison of geochemical compositions of rocks of the Lemhi Group in the Salmon River Mountains and the Lemhi Range is fraught with many limitations, not the least of which are the differing number of samples by rock type and formation in the two areas, the use of different analytical methods for trace elements and, perhaps, the different degree of 
metamorphism of rocks in the two areas. Nevertheless, a few comparisons between the same rocks types and formations may be attempted for major oxides, which were analyzed by the same method. In addition, comparisons of petrogenetic models derived by factor analysis seems worthwhile.

Siltite from the coarse siltite unit of the Apple Creek Formation is the most amenable rock for comparison between the two mountain ranges. Siltite samples from the coarse siltite unit number 15 in the Salmon River Mountains data set and 21 in the Lemhi Range data set (Table 1). Although the number of analyzed samples available for comparison is not large, no other formation or rock type has as many analyzed samples for comparison. Values for major oxides are possibly higher for $\mathrm{CaO}$ and lower for $\mathrm{P}_{2} \mathrm{O}_{5}$ in the coarse siltite unit of the Salmon River Mountains than in the Lemhi Range (Table 19). For all other oxides and LOI, no significant differences in values can be demonstrated. (The nonparametric U-test, discussed by Siegel (1956), was used because it is not affected by the nature of the underlying frequency distribution.) Evidently, metamorphic and other effects on composition were minor. The indication of no major change in major oxide content during regional metamorphism is not surprising, having been documented long ago for other regions (e. g., Shaw, 1956).

Table 19.--Median values and results of Mann-Whitney U-test for major oxides in the coarse siltite unit (Yac) of the Apple Creek Formation, Salmon River Mountains and Lemhi Range, Idaho. Results apply solely to rock type "siltite." $\mathrm{PCT}$, weight percent; $\mathrm{Fe}_{\mathrm{T}} \mathrm{O}_{3}$, total iron as $\mathrm{Fe}_{2} \mathrm{O}_{3}$; LOI, loss on ignition. Salmon, Salmon River Mountains; Lemhi, Lemhi Range. R1/n1, rank sum divided by number of samples (15), Salmon River Mountains; R2/n2, rank sum divided by number of samples (21), Lemhi Range. U-test statistics defined in Siegel (1956); P-value is the probability that the values from the Salmon River Mountains and the Lemhi Range are from the same population. S, significant at 0.05 level.

\begin{tabular}{|c|c|c|c|c|c|c|c|}
\hline \multirow{2}{*}{$\begin{array}{l}\text { Oxide } \\
\text { (PCT) }\end{array}$} & \multicolumn{2}{|c|}{ Medians } & \multicolumn{5}{|c|}{ U-test statistics } \\
\hline & Salmon & Lemhi & $\mathrm{R} 1 / \mathrm{n} 1$ & $\mathrm{R} 2 / \mathrm{n} 2$ & $\overline{\mathrm{U}}$ & Z-value & P-value \\
\hline $\mathrm{SiO}_{2}$ & 73.20 & 71.20 & 21.37 & 16.45 & 114.5 & -1.380 & .1677 \\
\hline $\mathrm{Al}_{2} \mathrm{O}_{3}$ & 12.60 & 13.40 & 16.47 & 19.95 & 127.0 & -.979 & .3227 \\
\hline $\mathrm{Fe}_{\mathrm{T}} \mathrm{O}_{3}$ & 5.20 & 4.18 & 20.70 & 16.93 & 124.5 & -1.059 & 2897 \\
\hline $\mathrm{MgO}$ & 1.15 & 1.04 & 20.33 & 17.19 & 130.0 & -.882 & .3776 \\
\hline $\mathrm{CaO}$ & .46 & .31 & 22.13 & 15.91 & 103.0 & -1.749 & .0803 \\
\hline $\mathrm{Na}_{2} \mathrm{O}$ & 3.18 & 3.36 & 17.63 & 19.12 & 144.5 & -.417 & .6766 \\
\hline $\mathrm{K}_{2} \mathrm{O}$ & 2.40 & 3.15 & 15.80 & 20.43 & 117.0 & -1.300 & 1938 \\
\hline $\mathrm{TiO}_{2}$ & .45 & .47 & 18.17 & 18.74 & 152.5 & -.160 & .8725 \\
\hline $\mathrm{P}_{2} \mathrm{O}_{5}$ & .10 & .18 & 8.50 & 25.64 & 7.5 & -4.874 & $<.0001$ \\
\hline MnO & .03 & .02 & 19.33 & 17.91 & 145.0 & -.401 & .6884 \\
\hline LOI & 1.39 & 1.49 & 18.73 & 18.33 & 154.0 & -.112 & .9106 \\
\hline
\end{tabular}


Petrogenetic comparisons (Tables 6 and 14) may be informative in comparisons of Mesoproterozoic metasedimentary rocks of the Salmon River Mountains and the Lemhi Range. In making such comparisons, it must be remembered that the Big Creek Formation was sampled only in the Lemhi Range and the Gunsight Formation was sampled only in the Salmon River Mountains. Only the Apple Creek Formation was sampled in both ranges, and even so, the units within the Apple Creek are not the same for both ranges. Nevertheless, in both ranges, rocks of the Lemhi Group show the effects of mica content (grain size of original sediment) and provenance (plagioclase) on major oxide and trace element composition. Probably, the mica (grain size) factor is a near-universal feature of clastic sedimentary rocks. The presence of a rare earth factor, of uncertain origin but tentatively interpreted as provenance or metamorphism, could not be detected in rocks of the Lemhi Range because suitable analytical data for $\mathrm{Ce}$ and $\mathrm{Nd}$ are not available. Except for locally anomalous copper, rocks of the Apple Creek Formation of the Lemhi Range show less evidence of mineralization than do those of the Salmon River Mountains, but analyses of critical elements such as As and $\mathrm{Zn}$ are not available. Taking into account the differences in analytical data represented in the two data sets, and differences in the formations sampled, the presence of the plagioclase (provenance) factor in rocks of both ranges is consistent with correlation with units of the same stratigraphic group.

\section{CLASSIFICATION BY MAJOR-OXIDE RATIOS}

The major oxide composition of the Big Creek, Apple Creek, and Gunsight Formations was investigated by use of major oxide ratio scattergrams. The use of ratio scattergrams and other, related methods for classification of sandstone (Lindsey, 1999) can be extended to other clastic sedimentary rocks (e.g., Herron, 1988). The fields shown on each scattergram are those commonly observed for clastic sedimentary rocks, but classification by major oxide ratios is not always conclusive. Other features, notably mineralogy and proportion of matrix, define the various classes of sandstone (e.g., Williams and others, 1954).

Interpretation of ratio scattergrams is complex and depends on knowledge of mineralogy and grain size. $\mathrm{Log} \mathrm{SiO}_{2} / \mathrm{Al}_{2} \mathrm{O}_{3}$ is a measure of quartz enrichment relative to other silicates. In sandstones, $\log \mathrm{SiO}_{2} / \mathrm{Al}_{2} \mathrm{O}_{3}$ is a measure of quartz versus feldspar plus clay, and is thus an indicator of chemical and textural maturity; in clastic rocks of varying grain size, $\log \mathrm{SiO}_{2} / \mathrm{Al}_{2} \mathrm{O}_{3}$ is essentially a measure of quartz versus clay, and thus is an indicator of grain size. Log $\mathrm{K}_{2} \mathrm{O} / \mathrm{Na}_{2} \mathrm{O}$ measures the degree to which potassium dominates the alkalis. In the rocks under study, $\mathrm{K}_{2} \mathrm{O}$ is dependent on metamorphic mica content, and thus reflects the original grain size of the sediment, whereas $\mathrm{Na}_{2} \mathrm{O}$ is dependent on plagioclase content, and thus reflects provenance (nature of source rocks, weathering of the source, and destruction during transport). In part, the ratio $\log \mathrm{K}_{2} \mathrm{O} / \mathrm{Na}_{2} \mathrm{O}$ reflects the degree to which plagioclase $\left(\mathrm{Na}_{2} \mathrm{O}\right)$-rich source rocks are broken down and converted to clay $\left(\mathrm{K}_{2} \mathrm{O}\right)$-rich sediment. In view of the factor models (Tables 6 and 14), interpretation of $\log \left(\left(\mathrm{Fe}_{\mathrm{T}} \mathrm{O}_{3}+\mathrm{MgO}\right) /\left(\mathrm{Na}_{2} \mathrm{O}+\mathrm{K}_{2} \mathrm{O}\right)\right)$, sometimes used in chemical classification of sandstone, may be hopelessly complex. At most, the ratio may be interpreted as the complex result of the degree of concentration of heavy iron oxide minerals, which is the result of both concentration by currents and destruction by diagenesis, and the abundance of chloritic $(\mathrm{MgO})$ matrix, here probably the product of both diagenesis and metamorphism, versus whatever factors (provenance, grain size) determine the sum $\mathrm{Na}_{2} \mathrm{O}+\mathrm{K}_{2} \mathrm{O}$. These three ratios are combined (Fig. 18) as scattergrams showing $\log \mathrm{SiO}_{2} / \mathrm{Al}_{2} \mathrm{O}_{3}$ vs $\log \mathrm{K}_{2} \mathrm{O} / \mathrm{Na}_{2} \mathrm{O}$ and $\log \left(\left(\mathrm{Fe}_{\mathrm{T}} \mathrm{O}_{3}+\right.\right.$ $\left.\mathrm{MgO}) /\left(\mathrm{Na}_{2} \mathrm{O}+\mathrm{K}_{2} \mathrm{O}\right)\right)$ to classify sandstones and other siliciclastic sedimentary rocks (Pettijohn and others, 1972; Lindsey, 1999).

A third ratio scattergram (Fig. 19), $\log \mathrm{Fe}_{\mathrm{T}} \mathrm{O}_{3} / \mathrm{K}_{2} \mathrm{O}$ vs $\log \mathrm{SiO}_{2} / \mathrm{Al}_{2} \mathrm{O}_{3}$, has been used to distinguish some groups of sandstones from argillaceous rocks (Herron, 1988). In rocks of varying grain size, and in matrix-rich sandstone, $\log \mathrm{Fe}_{\mathrm{T}} \mathrm{O}_{3} / \mathrm{K}_{2} \mathrm{O}$ is a good measure of the abundance of iron-bearing chlorite versus potassium-bearing clays and micas. In rocks of the Lemhi Group, because both $\mathrm{K}_{2} \mathrm{O}$ and $\mathrm{Al}_{2} \mathrm{O}_{3}$ are dependent on mica content, and thus original sediment grain size, the scattergram of Herron (1988) is suitable for classifying these rocks. Inspection of ratio scattergrams of rocks from the Salmon River Mountains and Lemhi Ranges (Figs. 18 and 19) indicates the chemical resemblance of sandstones to graywacke, 
arkose, and lithic arenite. Thus, all three major classes of sandstone may be represented. In the scattergram $\log \mathrm{SiO}_{2} / \mathrm{Al}_{2} \mathrm{O}_{3}$ vs $\log \mathrm{K}_{2} \mathrm{O} / \mathrm{Na}_{2} \mathrm{O}$ (Fig. 18), all three rock types--sandstone, siltite, and argillite--are seen to be chemically immature (silica- or quartz-poor), strongly suggesting that, before metamorphism, they were for the most part first-cycle clastic sediments. In the scattergram $\log \mathrm{Fe}_{\mathrm{T}} \mathrm{O}_{3} / \mathrm{K}_{2} \mathrm{O}$ vs $\log \mathrm{SiO}_{2} / \mathrm{Al}_{2} \mathrm{O}_{3}$, sandstones appear to be well-represented in the litharenite and arkose fields, whereas siltites, argillites, and diamictites plot mostly within the wacke (graywacke) field (Fig. 19). The chemical resemblance of fine-grained rocks (argillites, diamictites, and siltites) in both the Salmon River Mountains and Lemhi Rangeto graywackes reflects abundant chlorite and iron oxides in matrix, which may originally have been clay.

A notable feature of scattergrams showing $\log \mathrm{K}_{2} \mathrm{O} / \mathrm{Na}_{2} \mathrm{O}$ (Fig. 18) is the strong linear trend of all rock types, reflecting a wide variation in $\mathrm{K}_{2} \mathrm{O} / \mathrm{Na}_{2} \mathrm{O}$. This variation could result from 1) mixing of two source rocks, one $\mathrm{K}_{2} \mathrm{O}$ (potassium feldspar and mica)-rich and one $\mathrm{Na}_{2} \mathrm{O}$ (plagioclase)-rich, or from 2) varying degrees of weathering of initially $\mathrm{Na}_{2} \mathrm{O}$ (plagioclase)-rich rock, either in the source area, during transit to the depositional basin, or both. Variation in log $\mathrm{K}_{2} \mathrm{O} / \mathrm{Na}_{2} \mathrm{O}$, interpreted as the degree to which plagioclase-rich source rocks are broken down and converted into clay-rich sediment, is the same as comparing the scores of the mica (grain size) factor 1 with the plagioclase (provenance) factor 4, interpreted from R-mode factor analysis (Tables 6 and 14). If $\log \mathrm{K}_{2} \mathrm{O} / \mathrm{Na}_{2} \mathrm{O}$ values represent mixing of two rocks, then ratios at the ends of the line should approximate those of the source rocks. If $\log \mathrm{K}_{2} \mathrm{O} / \mathrm{Na}_{2} \mathrm{O}$ represents weathering of an originally $\mathrm{Na}_{2} \mathrm{O}$ (plagioclase)-rich source rock, then the ratio at the $\mathrm{Na}_{2} \mathrm{O}$-rich end of the trend should approximate the value of the source. 


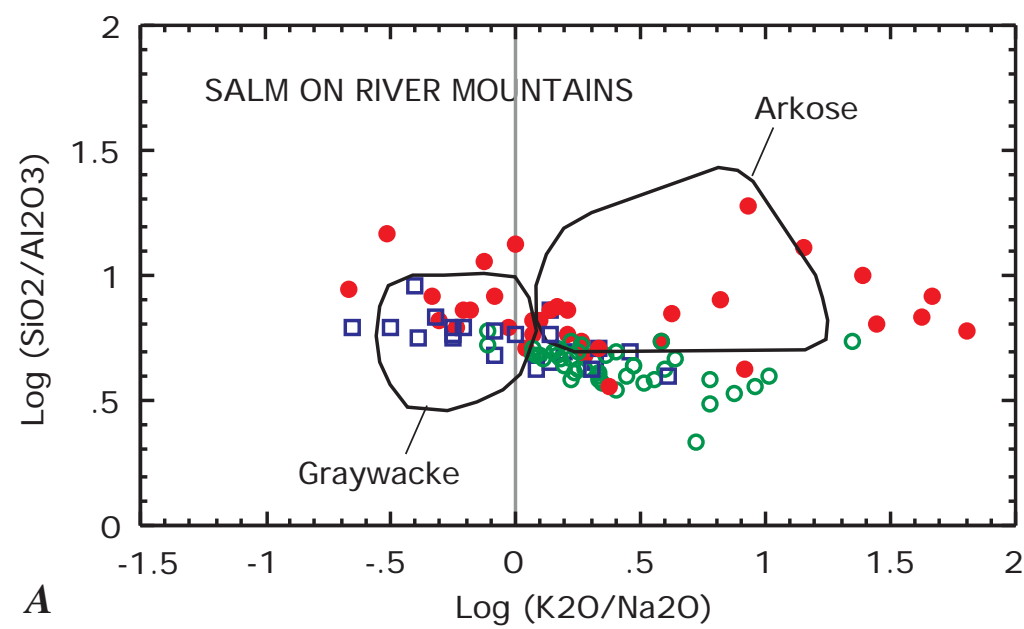

\section{EXPLANATION}

- Argillite

Siltite

- Sandstone

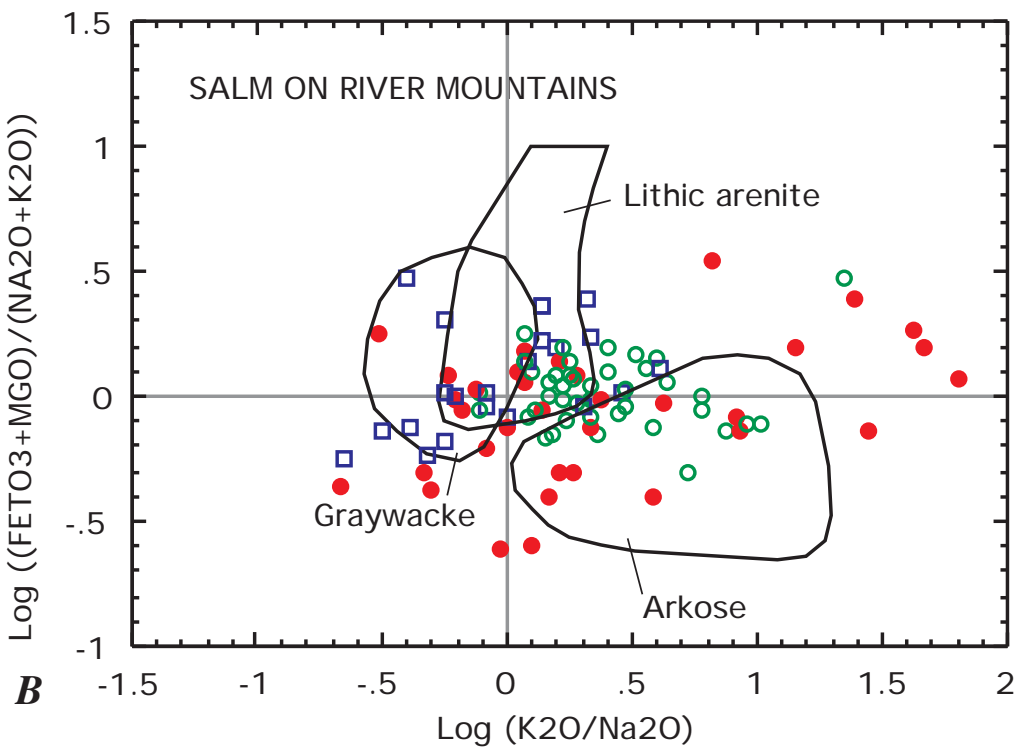

Figure 18.--Chemical classification of Lemhi Group rocks by $\mathrm{SiO}_{2} / \mathrm{Al}_{2} \mathrm{O}_{3}$ vs $\log \mathrm{K} 2 \mathrm{O} / \mathrm{Na}_{2} \mathrm{O}$ and $\log \left(\left(\mathrm{Fe}_{\mathrm{T}} \mathrm{O}_{3}+\mathrm{MgO}\right) /\left(\mathrm{Na}_{2} \mathrm{O}+\mathrm{K}_{2} \mathrm{O}\right)\right)$ (method of Pettijohn and others, 1972, modified by Lindsey, 1999): A) $\log \mathrm{SiO}_{2} / \mathrm{Al}_{2} \mathrm{O}_{3}$ vs $\log \mathrm{K}_{2} \mathrm{O} / \mathrm{Na}_{2} \mathrm{O}$, Apple Creek and Gunsight Formations, Salmon River Mountains, B) $\log \left(\left(\mathrm{Fe}_{\mathrm{T}} \mathrm{O}_{3}+\mathrm{MgO}\right) /\left(\mathrm{Na}_{2} \mathrm{O}+\mathrm{K}_{2} \mathrm{O}\right)\right)$, Apple Creek and Gunsight Formations, Salmon River Mountains, C), $\log \mathrm{SiO}_{2} / \mathrm{Al}_{2} \mathrm{O}_{3}$ vs $\log \mathrm{K} 2 \mathrm{O} / \mathrm{Na}_{2} \mathrm{O}$, Big Creek and Apple Creek Formations, Lemhi Range, and D) $\log \left(\left(\mathrm{Fe}_{\mathrm{T}} \mathrm{O}_{3}+\mathrm{MgO}\right) /\left(\mathrm{Na}_{2} \mathrm{O}\right.\right.$ $\left.+\mathrm{K}_{2} \mathrm{O}\right)$ ), Big Creek and Apple Creek Formations, Lemhi Range. Fields shown for representative graywacke, arkose, and lithic arenite (Pettijohn and others, 1972). 


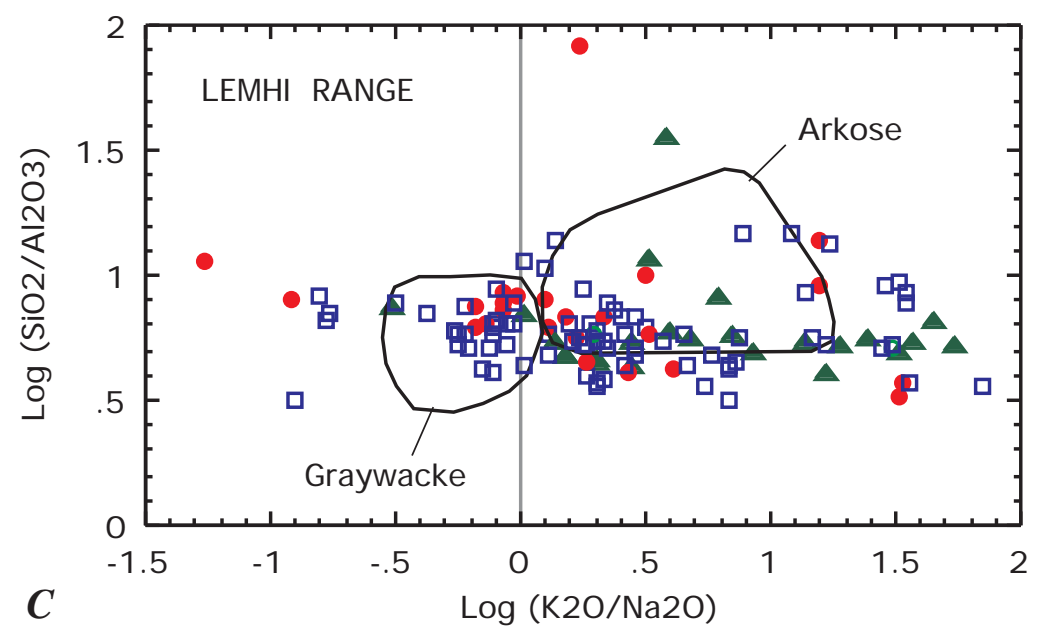
EXPLANATION
- Argillite
- Diamictite
a Siltite
- Sandstone

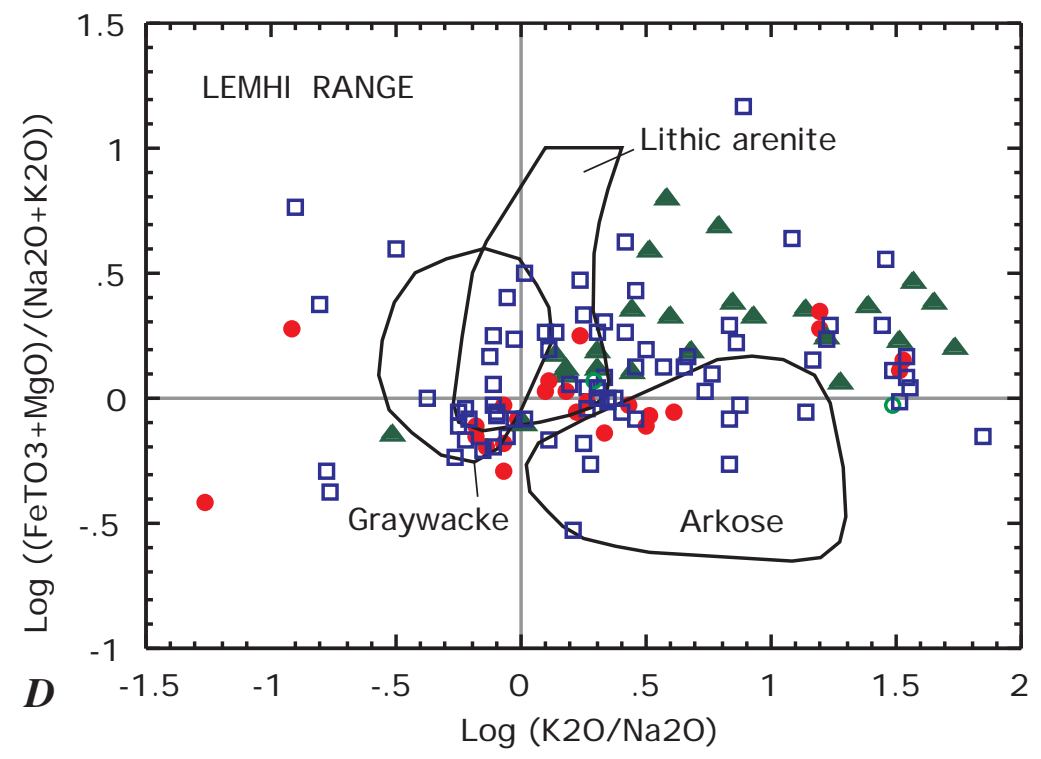

Figure 18.--Continued. 


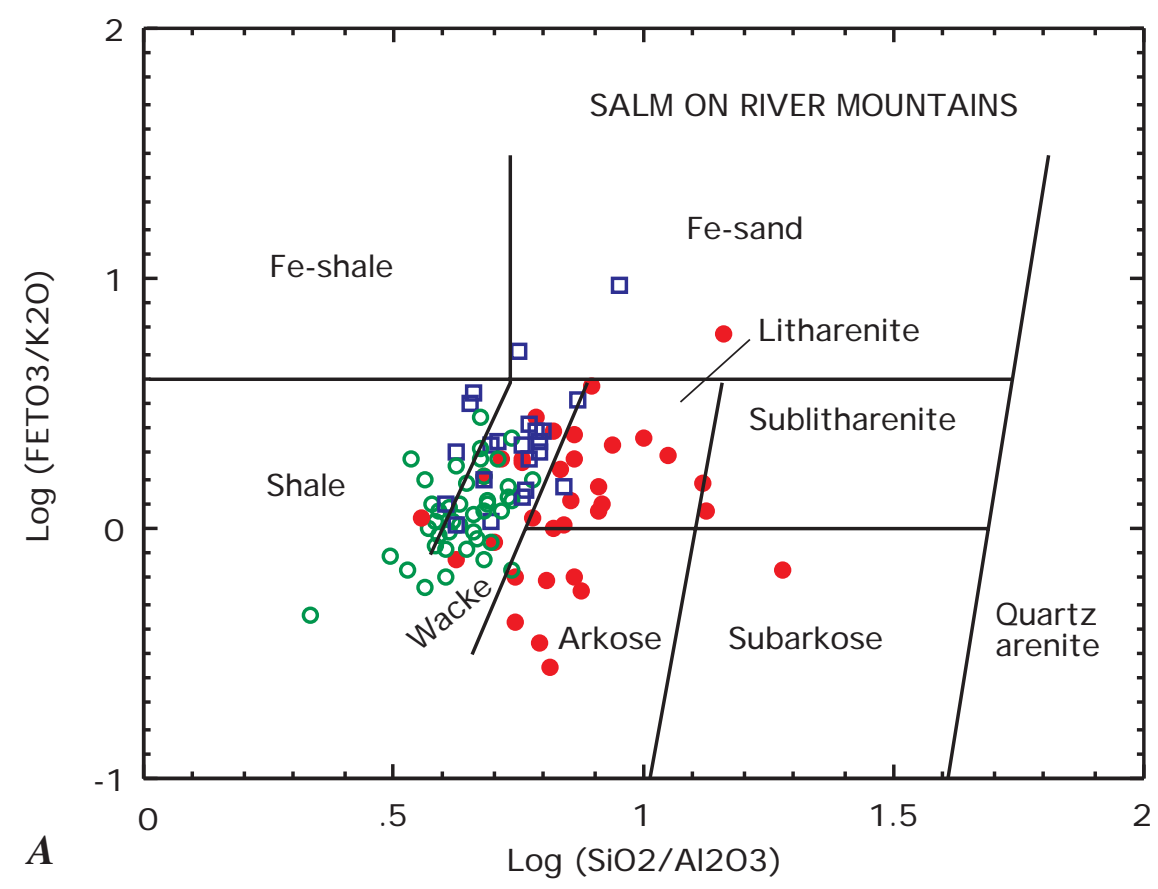
EXPLANATION
- Argillite
- Diamictite
- Sandstone
a Siltite

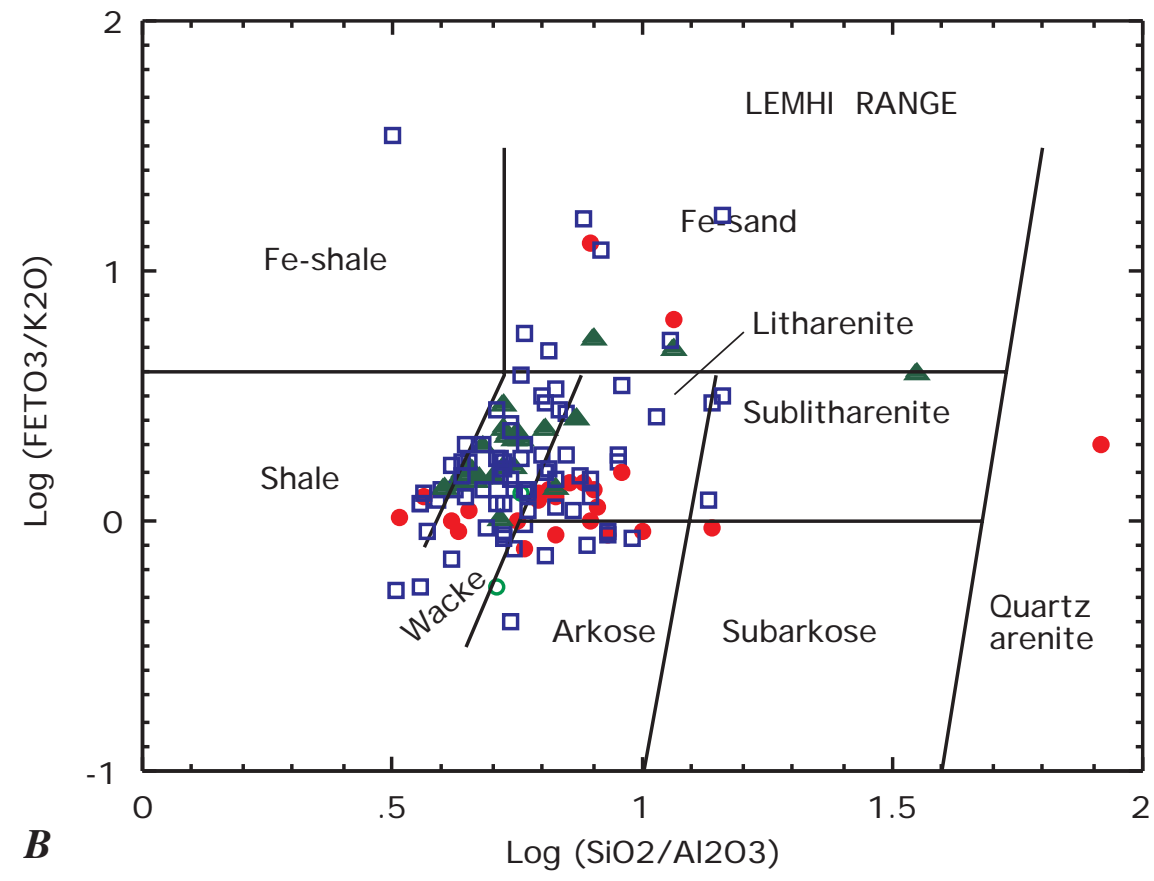

Figure 19.--Chemical classification of Lemhi Group rocks by $\log \mathrm{Fe}_{\mathrm{T}} \mathrm{O}_{3} / \mathrm{K}_{2} \mathrm{O}$ vs $\log \mathrm{SiO}_{2} / \mathrm{Al}_{2} \mathrm{O}_{3}$ (method of Herron, 1988): A) Apple Creek and Gunsight Formations, Salmon River Mountains and B) Big Creek and Apple Creek Formations, Lemhi Range. 


\section{REFERENCES CITED}

Argast, S., and Donnelly, T.W., 1987, The chemical discrimination of clastic sedimentary components: Journal of Sedimentary Petrology, v. 57, no. 5, p. 813-823.

Baedecker, P.A., Grossman, J.N., and Buttleman, K.P., 1998, National Geochemical Data Base: PLUTO Geochemical data base for the United States: U.S. Geological Survey Digital Data Series DDS-47 (CD-ROM).

Bouch, J.E., Hole, M.J., and Trewin, N.H., 1997, Rare earth and high field strength element partitioning behaviour in diagenetically precipitated titanites: Neues Jahrbuch für Mineralogie Abhandlungen, v. 172, no. 1, p. 3-21.

Chayes, F., 1960, On correlation between variables of constant sum: Journal of Geophysical Research, v. 65, no. 12, p. 4185-4193.

Connor, J.J., 1990, Geochemical stratigraphy of the Yellowjacket Formation (Middle Proterozoic) in the area of the Idaho Cobalt Belt, Lemhi County, Idaho, with Analytical contributions from A.J. Bartel, E. Brandt, P. H. Briggs, S. Danahey, D. Fey, D.B. Hatfield, M. Malcolm, V. Merritt, G. Riddle, S. Roof, K. Stewart, J. Storey, J.E. Taggart, Jr., and R.B. Vaughn: U.S. Geological Survey Open-File Report 90-0234 (Part A, Discussion, 29 p.; Part B, Geochemical data files, 1 diskette).

Connor, J.J., 1991a, Some geochemical features of the Blackbird and Jackass zones of the Yellowjacket Formation (Middle Proterozoic) in east-central Idaho, with Analytical contributions from A.J. Bartel, P.H. Briggs, R.R. Carlson, J.G. Crock, B.H. Roushey, C.S.E. Papp, D.F. Siems, J.E. Taggart, Jr., and E.P. Welsch: U.S. Geological Survey Open-File Report 91-0259 (Part A, Discussion, 25 p.; Part B, Geochemical data files, diskette).

1991b, Geochemical variation in a copper-bearing redbed sequence of the Ravalli Group (Belt Supergroup), northwestern Montana and northern Idaho, with Analytical contributions from A.J. Bartel, E. Brandt, J.G. Crock, S. Danahey, M. Malcolm, G. Mason, V. Merritt, K. Stewart, J. Storey, J.E. Taggart, Jr., and R.B. Vaughn: U.S. Geological Survey Open-File Report 91-0028 (Part A, Geological interpretation, 47 p.; Part B, Geochemical data, 4 p., 1 diskette).

Connor, J.J., and Evans, K.V., 1986, Geologic map of the Leesburg quadrangle, Lemhi County, Idaho: U.S. Geological Survey Miscellaneous Field Studies Map MF-1880, scale 1:62,500.

Cooley, W.W., and Lohnes, P.R., 1962, Multivariate procedures for the behaviorial sciences: New York, Wiley, $211 \mathrm{p}$.

Dana, E.S., 1932, A textbook of mineralogy, with an extended treatise on crystallography and physical mineralogy (Fourth Edition, revised and enlarged by W. E. Ford): New York, Wiley, 851 p.

Deer, W.A., Howie, R.A., and Zussman, J., 1963, Rock-forming minerals, v. 4: Framework silicates: New York, John Wiley, $435 \mathrm{p}$. 1966, An introduction to the rock-forming minerals: New York, John Wiley, $528 \mathrm{p}$. 1982, Rock-forming minerals, Second Edition, Volume 1A, Orthosilicates: London, Longman, 919 p.

Evans, K.V., and Connor, J.J., 1993, Geologic map of the Blackbird Mountain 15-minute quadrangle, Lemhi County, Idaho: U.S. Geological Survey Miscellaneous Field Studies Map MF-2234, scale 1:62,500.

Floyd, P.A., Shail, R., Leveridge, B.E., and Frank, W., 1991, Geochemistry and provenance of Rhenohercynian synorogenic sandstones: implications for tectonic environment discrimination, in: Morton, A.C., Todd, S.P., and Haughton, P.D.W. eds., Developments in Sedimentarhy Provenance Studies, Geological Society of London Special Publication No. 57, p. 173-188.

Golightly, D.W., Dorrzapf, A.F., Jr., Mays, R.E., Fries, T.L., and Conklin, N.M., 1987, Analysis of geologic materials by direct-current arc emission spectrography and spectrometry, in Baedecker, P.A., ed., Methods of geochemical analysis: U.S. Geological Survey Bulletin 1770, p. A1-A13.

Herron, M.M., 1988, Geochemical classification of terrigenous sands and shales from core or log data: Journal of Sedimentary Petrology, v. 58, no. 5, p. 820-829.

Herron, M.M., and Matteson, A., 1993, Elemental composition and nuclear parameters of some common sedimentary minerals: Nuclear Geophysics, v. 7, no. 3, p. 383-406.

Hubert, J. F., Feshbach-Meriney, P.E., and Smith, M.A., 1992, The Triassic-Jurassic Hartford rift basin, Connecticut and Massachusetts: evolution, sandstone diagenesis, and hydrocarbon history: American Association of Petroleum Geologists Bulletin, v. 76, no. 11, p. 1710-1734.

Hunt, J. A., and Kerrick, D.M., 1977, The stability of sphene: experimental redetermination and geologic implications: Geochimica et Cosmochimica Acta, v. 41, no. 2, p. 279-288.

Jackson, D.A., 1993, Stopping rules in principal components analysis; a comparison of heuristical and statistical approaches: Ecology, v. 74, no. 8, p. 2204-2214. 
Lichte, F.E., Golightly, D.W., and Lamothe, P.J., 1987, Inductively couple plasma-atomic emission spectrometry, in Baedecker, P.A., ed., Methods of geochemical analysis: U.S. Geological Survey Bulletin 1770, p. B1- B10.

Lindsey, D.A., 1999, An evaluation of alternative chemical classifications of sandstones: U.S. Geological Survey Open-File Report 99-346, 23 p.

Lopez, D.A., 1981, Stratigraphy of the Yellowjacket Formation of east-central Idaho: U.S. Geological Survey Open-File Report 81-1088, 203 p.

McKown, D.M., and Millard, H.T., Jr., 1987, Determination of uranium and thorium by delayed neutron counting, in Baedecker, P.A., ed., Methods of geochemical analysis: U.S. Geological Survey Bulletin 1770, p. I1- I12.

McLennan, S.M., 1989, Rare earth elements in sedimentary rocks: influence of provenance and sedimentary processes, in Lipin, B.R., and McKay, G.A., eds., Geochemistry and Mineralogy of Rare Earth Elements, Mineralogical Society of America, Reviews in Mineralogy, v. 21, p. 169-200.

Middleton, G.V., 1972, Albite of secondary origin in Charny sandstones, Quebec: Journal of Sedimentary Petrology, v. 42, no. 2, p. 341-349.

Nash, J.T., 1989, Geology and geochemistry of synsedimentary cobaltiferous-pyrite deposits, Iron Creek, Lemhi County, Idaho: U.S. Geological Survey Bulletin 1882, 33 p.

Ohr, M., Halliday, A.N., and Peacor, D.R., 1994, Mobility and fractionation of rare earth elements in argillaceous sediments: implications for dating diagensis and low-grade metamorphism: Geochimica et Cosmochimica Acta, v. 58, no. 1, p. 289-312.

Pettijohn, F.J., Potter, P.E., and Siever, R., 1972, Sand and sandstone: New York, Springer, 618 p.

Reyment, R.A., and Savazzi, E., 1999, Aspects of multivariate statistical analysis in geology: Amsterdam, Elsevier, $285 \mathrm{p}$.

SAS Institute Inc., 1998, Statview reference, Second Edition: Cary, N.C., 528 p.

Shaw, D.M., 1956, Geochemistry of pelitic rocks. Part III: Major elements and general geochemistry: Geological Society of America Bulletin, v. 67, no. 7, p. 919-934.

Siegel, S., 1956, Nonparametric statistics for the behaviorial sciences: New York, McGraw-Hill, 312 p.

Smith, J.V., 1975, Some chemical properties of feldspars, in Feldspar Mineralogy, Mineralogical Society of America, Short Course Notes: Southern Printing Company, Blackburg, Va., p. Sm 18-29.

Smith, J.V., and Brown, W.L., 1988, Feldspar minerals, Second Edition-Volume 1, Crystal structures; physical, chemical and microtextural properties: New York, Springer, $828 \mathrm{p}$.

Snedecor, G.W., and Cochran, W.G., 1967, Statistical methods: Ames, Iowa, Iowa State University Press, 593 p.

Taggart, J.E., Jr., Lindsay, J.R., Scott, B.A., Vivit, D.V., Bartel, A.J., and Stewart, K.C., 1987, Analysis of geologic materials by wavelength-dispersive X-ray fluorescence spectrometry, in Baedecker, P.A., ed., Methods of geochemical analysis: U.S. Geological Survey Bulletin 1770, p. E1-E19.

Tietbohl, D., 1986, Middle Proterozoic diamictite beds in the Lemhi Range, east-central Idaho, in Roberts, S. M., ed., Belt Supergroup: a guide to Proterozoic rocks of western Montana and adjacent areas: Montana Bureau of Mines Special Publication 94, p. 197-207.

Tysdal, R.G., 1996a, Geologic map of the Lem Peak quadrangle, Lemhi County, Idaho: U.S. Geological Survey Geologic Quadrangle Map GQ-1777, scale 1:24,000. 1996b, Geologic map of adjacent areas in the Hayden Creek and Mogg Mountain Quadrangles, Lemhi County, Idaho: U.S. Geological Survey Geologic Quadrangle Map GQ-2563, scale 1:24,000. 2000a, Revision of Middle Proterozoic Yellowjacket Formation, central Idaho: U.S. Geological Survey Professional Paper 1601-A, 14 p.. , 2000b, Stratigraphy and depositional environments of Middle Proterozoic rocks in northern part of Lemhi Range, Lemhi County, Idaho: U.S. Geological Survey Professional Paper 1600, 40 p.

Tysdal, R.G., and Moye, F., 1996, Geologic map of the Allison Creek Quadrangle, Lemhi County, Idaho: U.S. Geological Survey Geologic Quadrangle Map GQ-1778, scale 1:24,000.

Van de Kamp, P.C., and Leake, B.E., 1994, Petrology, geochemistry, provenance, and alteration of PennsylvanianPermian arkose, Colorado and Utah: Geological Society of America Bulletin, v. 105, no. 12, p. 1581-1582.

Velbel, M.A., and Saad, M.K., 1991, Paleoweathering or diagenesis as the principal modifier of sandstone framework composition? A case study from some Triassic rift-valley redbeds of eastern North America, in: Morton, A.C., Todd, S.P., and Haughton, P.D.W., eds., Developments in Sedimentarhy Provenance Studies, Geological Society of London Special Publication No. 57, p. 91-99.

Vine, J.D., and Tourtelot, E.B., 1970, Geochemistry of black shale deposits: a summary report: Economic Geology, v. 65 , no. 3 , p. $253-272$. 
Williams, H., Turner, F.J., and Gilbert, C.M., 1954, Petrography: an introduction ot the study of rocks in thin sections: San Francisco, Freeman, 406 p.

Zhu, X.K., and O’Nions, R.K., 1999, Monazite chemical composition: some implications for monzazite geochronology: Contributions to Mineralogy and Petrology, v. 137, no. 4, p. 351-363. 


\section{APPENDIX TABLES 1-2}

Appendix Table 1.--Correlation matrix (35X35) for 98 samples (34 sandstones, 22 siltites, and 42 argillites) of the Apple Creek and Gunsight Formations, Salmon River Mountains (calculated from data of Connor, 1990). Coefficients reflect replacement of "less than" values in Table 2. $\mathrm{Fe}_{\mathrm{T}} \mathrm{O}_{3}$, total iron as $\mathrm{Fe}_{2} \mathrm{O}_{3}$; LOI, loss on ignition.

\begin{tabular}{|c|c|c|c|c|c|c|c|c|c|c|c|c|}
\hline & $\mathrm{SiO} 2$ & $\mathrm{Al} 2 \mathrm{O} 3$ & $\begin{array}{l}\text { Log } \\
\text { FeTO3 }\end{array}$ & $\begin{array}{l}\mathrm{Log} \\
\mathrm{MgO}\end{array}$ & $\log \mathrm{CaO}$ & $\mathrm{Na} 2 \mathrm{O}$ & $\mathrm{K} 2 \mathrm{O}$ & $\mathrm{TiO} 2$ & $\mathrm{P} 2 \mathrm{O} 5$ & LOI & $\log$ As & $\log B$ \\
\hline $\mathrm{SiO} 2$ & 1.000 & -.941 & -.433 & -.715 & -.383 & .128 & -.651 & -.810 & -.551 & -.727 & -.216 & -.324 \\
\hline $\mathrm{Al} 2 \mathrm{O} 3$ & -.941 & 1.000 & .213 & .586 & .336 & -.076 & .647 & .712 & .455 & .693 & .196 & .280 \\
\hline Log FeTO3 & -.433 & .213 & 1.000 & .484 & -.069 & -.289 & .214 & .402 & .290 & .292 & .169 & .078 \\
\hline Log $\mathrm{MgO}$ & -.715 & .586 & .484 & 1.000 & .357 & -.157 & .362 & 649 & .497 & .567 & .230 & .337 \\
\hline $\log \mathrm{CaO}$ & -.383 & .336 & -.069 & .357 & 1.000 & .512 & -.207 & .421 & .556 & .340 & .265 & .198 \\
\hline $\mathrm{Na} 2 \mathrm{O}$ & .128 & -.076 & -.289 & -.157 & .512 & 1.000 & -.585 & -.035 & .091 & -.350 & .077 & -.141 \\
\hline $\mathrm{K} 2 \mathrm{O}$ & -.651 & .647 & .214 & .362 & -.207 & -.585 & 1.000 & .403 & .142 & .369 & -.122 & .280 \\
\hline $\mathrm{TiO} 2$ & -.810 & .712 & .402 & 649 & .421 & -.035 & .403 & 1.000 & .626 & .605 & .319 & .346 \\
\hline $\mathrm{P} 2 \mathrm{O} 5$ & -.551 & .455 & .290 & .497 & .556 & .091 & .142 & .626 & 1.000 & .472 & .274 & .238 \\
\hline LOI & -.727 & .693 & .292 & .567 & .340 & -.350 & .369 & .605 & .472 & 1.000 & .360 & .313 \\
\hline Log As & -.216 & .196 & .169 & .230 & .265 & .077 & -.122 & .319 & .274 & .360 & 1.000 & -.014 \\
\hline $\log B$ & -.324 & .280 & .078 & .337 & .198 & -.141 & .280 & .346 & .238 & .313 & -.014 & 1.000 \\
\hline $\log \mathrm{Ba}$ & -.479 & .455 & .112 & .208 & -.098 & -.373 & .774 & .331 & .180 & .228 & -.151 & .066 \\
\hline $\mathrm{Be}$ & -.794 & .839 & .168 & .514 & .326 & -.207 & .588 & .640 & .353 & .684 & .109 & .236 \\
\hline $\log \mathrm{Ce}$ & -.119 & .045 & .168 & .195 & .345 & .163 & -.100 & .141 & .197 & .103 & .070 & .076 \\
\hline Log Co & -.504 & .376 & .571 & .531 & .265 & -.046 & .100 & .441 & .273 & .455 & .323 & -.084 \\
\hline $\mathrm{Cr}$ & -.618 & .521 & .227 & .490 & .315 & .008 & .297 & .798 & .395 & .460 & .257 & .225 \\
\hline $\log \mathrm{Cu}$ & .014 & -.023 & .095 & -.067 & .118 & .282 & -.257 & .026 & -.032 & .044 & .139 & -.199 \\
\hline $\log \mathrm{Ga}$ & -.931 & .935 & .348 & .654 & .286 & -.200 & .663 & .715 & .402 & .730 & .164 & .312 \\
\hline $\mathrm{La}$ & -.144 & .076 & .114 & .250 & .369 & .198 & -.104 & .189 & .186 & .127 & .091 & .215 \\
\hline $\log \mathrm{Li}$ & -.761 & .699 & .352 & .757 & .415 & -.110 & .420 & .657 & .400 & .648 & .314 & .329 \\
\hline $\log \mathrm{Mn}$ & -.340 & .224 & .243 & .356 & .538 & .170 & -.098 & .333 & .347 & .412 & .289 & -.057 \\
\hline $\mathrm{Nd}$ & -.192 & .127 & .119 & .298 & .374 & .162 & -.035 & .222 & .199 & .157 & .096 & .263 \\
\hline $\mathrm{Ni}$ & -.610 & .464 & .344 & .700 & .473 & -.027 & .220 & 699 & .475 & .540 & .332 & .251 \\
\hline $\log \mathrm{Pb}$ & -.038 & .019 & .030 & -.071 & .253 & .274 & -.231 & .068 & .207 & .073 & .354 & -.209 \\
\hline $\log \mathrm{Sb}$ & -.226 & .157 & .228 & .250 & .266 & .097 & -.056 & .253 & .462 & .299 & .498 & .124 \\
\hline $\mathrm{Sc}$ & -.848 & .776 & .350 & .661 & .350 & -.162 & .529 & .923 & .572 & .676 & .306 & .281 \\
\hline $\log \mathrm{Sr}$ & -.180 & .199 & -.220 & .131 & .697 & .662 & -.266 & .254 & .188 & -.000 & .078 & .023 \\
\hline Log Th & -.737 & .695 & .301 & .528 & .308 & -.042 & .443 & .646 & .360 & .521 & .070 & .359 \\
\hline $\mathrm{U}$ & -.676 & .604 & .427 & .583 & .335 & -.036 & .332 & .618 & .457 & .555 & .247 & .224 \\
\hline V & -.776 & .695 & .371 & .575 & .246 & -.190 & .502 & .895 & .445 & .606 & .315 & .261 \\
\hline $\log Y$ & -.328 & .273 & .142 & .395 & .635 & .293 & -.020 & .358 & .478 & .187 & .075 & .051 \\
\hline $\log \mathrm{Yb}$ & -.499 & .454 & .143 & .508 & .651 & .257 & .083 & .490 & .542 & .320 & .143 & .036 \\
\hline $\log \mathrm{Zn}$ & -.206 & .123 & .300 & .233 & .156 & -.006 & -.086 & .259 & .167 & .300 & .327 & -.217 \\
\hline $\log \mathrm{Zr}$ & -.532 & .423 & .392 & .308 & .082 & -.012 & .342 & .527 & .377 & .280 & -.049 & .156 \\
\hline
\end{tabular}

\begin{tabular}{|c|c|c|c|c|c|c|c|c|c|c|c|c|}
\hline & $\log \mathrm{Ba}$ & $\mathrm{Be}$ & $\log \mathrm{Ce}$ & $\log C o$ & $\mathrm{Cr}$ & $\log \mathrm{Cu}$ & $\log \mathrm{Ga}$ & $\mathrm{La}$ & $\log \mathrm{Li}$ & $\log M n$ & $\mathrm{Nd}$ & $\mathrm{Ni}$ \\
\hline $\mathrm{SiO} 2$ & -.479 & -.794 & -.119 & -.504 & -.618 & .014 & -.931 & -.144 & -.761 & -.340 & -.192 & -.610 \\
\hline $\mathrm{Al} 2 \mathrm{O} 3$ & .455 & .839 & .045 & .376 & .521 & -.023 & .935 & .076 & .699 & .224 & .127 & .464 \\
\hline Log FeTO3 & .112 & .168 & .168 & .571 & .227 & .095 & .348 & .114 & .352 & .243 & .119 & .344 \\
\hline Log $\mathrm{MgO}$ & .208 & .514 & .195 & .531 & .490 & -.067 & .654 & .250 & .757 & .356 & .298 & .700 \\
\hline $\log \mathrm{CaO}$ & -.098 & .326 & .345 & .265 & .315 & .118 & .286 & .369 & .415 & .538 & .374 & .473 \\
\hline $\mathrm{Na} 2 \mathrm{O}$ & -.373 & -.207 & .163 & -.046 & .008 & .282 & -.200 & .198 & -.110 & .170 & .162 & -.027 \\
\hline $\mathrm{K} 2 \mathrm{O}$ & .774 & .588 & -.100 & .100 & .297 & -.257 & .663 & -.104 & .420 & -.098 & -.035 & .220 \\
\hline $\mathrm{TiO} 2$ & .331 & .640 & .141 & .441 & .798 & .026 & .715 & .189 & .657 & .333 & .222 & .699 \\
\hline $\mathrm{P} 2 \mathrm{O} 5$ & .180 & .353 & .197 & .273 & .395 & -.032 & .402 & .186 & .400 & .347 & .199 & .475 \\
\hline LOI & .228 & .684 & .103 & .455 & .460 & .044 & .730 & .127 & .648 & .412 & .157 & .540 \\
\hline Log As & -.151 & .109 & .070 & .323 & .257 & .139 & .164 & .091 & .314 & .289 & .096 & .332 \\
\hline $\log B$ & .066 & .236 & .076 & -.084 & .225 & -.199 & .312 & .215 & .329 & -.057 & .263 & .251 \\
\hline $\log \mathrm{Ba}$ & 1.000 & .413 & -.021 & .094 & .359 & -.153 & .459 & -.036 & .281 & .049 & -.008 & .335 \\
\hline $\mathrm{Be}$ & .413 & 1.000 & .100 & .360 & .472 & -.143 & .814 & .135 & .677 & .240 & .196 & .457 \\
\hline $\log C e$ & -.021 & .100 & 1.000 & .224 & .060 & .223 & .073 & .878 & .371 & .398 & .872 & .280 \\
\hline Log Co & .094 & .360 & .224 & 1.000 & .350 & .216 & .431 & .186 & .478 & .517 & .174 & .505 \\
\hline $\mathrm{Cr}$ & .359 & .472 & .060 & .350 & 1.000 & .088 & .556 & .154 & .462 & .253 & .150 & .743 \\
\hline $\log \mathrm{Cu}$ & -.153 & -.143 & .223 & .216 & .088 & 1.000 & -.042 & .202 & .094 & .332 & .130 & .064 \\
\hline $\log \mathrm{Ga}$ & .459 & .814 & .073 & .431 & .556 & -.042 & 1.000 & .102 & .710 & .267 & .153 & .513 \\
\hline $\mathrm{La}$ & -.036 & .135 & .878 & .186 & .154 & .202 & .102 & 1.000 & .403 & .364 & .978 & .353 \\
\hline $\log \mathrm{Li}$ & .281 & .677 & .371 & .478 & .462 & .094 & .710 & .403 & 1.000 & .443 & .447 & .618 \\
\hline $\log \mathrm{Mn}$ & .049 & .240 & .398 & .517 & .253 & .332 & .267 & .364 & .443 & 1.000 & .342 & .510 \\
\hline $\mathrm{Nd}$ & -.008 & .196 & .872 & .174 & .150 & .130 & .153 & .978 & .447 & .342 & 1.000 & .362 \\
\hline $\mathrm{Ni}$ & .335 & .457 & .280 & .505 & .743 & .064 & .513 & .353 & .618 & .510 & .362 & 1.000 \\
\hline $\log \mathrm{Pb}$ & -.022 & -.054 & .245 & .195 & .104 & .440 & -.029 & .234 & .132 & .483 & .149 & .092 \\
\hline $\log \mathrm{Sb}$ & .024 & .018 & .218 & .243 & .176 & .057 & .152 & .205 & .228 & .299 & .192 & .272 \\
\hline
\end{tabular}




\begin{tabular}{|c|c|c|c|c|c|c|c|c|c|c|c|c|}
\hline $\mathrm{Sc}$ & .436 & .695 & .078 & .442 & .781 & -.040 & .799 & .102 & .660 & .317 & .145 & .710 \\
\hline $\log \mathrm{Sr}$ & -.034 & .153 & .357 & .180 & .244 & .188 & .123 & .359 & .282 & .456 & .336 & .321 \\
\hline $\log \mathrm{Th}$ & .332 & .642 & .238 & .393 & .470 & .054 & .708 & .343 & .629 & .241 & .361 & .414 \\
\hline $\mathrm{U}$ & .351 & .518 & .361 & .510 & .429 & .131 & .589 & .398 & .661 & .356 & .401 & .512 \\
\hline V & .443 & .632 & .003 & .421 & .887 & .028 & .725 & .041 & .580 & .243 & .068 & .702 \\
\hline $\log Y$ & .120 & .313 & .551 & .305 & .173 & .084 & .229 & .523 & .411 & .589 & .541 & .400 \\
\hline $\log \mathrm{Yb}$ & .195 & .439 & .311 & .328 & .328 & .060 & .374 & .307 & .477 & .584 & .325 & .489 \\
\hline $\log \mathrm{Zn}$ & .107 & .159 & .278 & .446 & .226 & .373 & .167 & .234 & .410 & .730 & .190 & .373 \\
\hline $\log \mathrm{Zr}$ & .263 & .372 & .187 & .333 & .393 & -.011 & .460 & .249 & .320 & .185 & .251 & .220 \\
\hline
\end{tabular}

\begin{tabular}{|c|c|c|c|c|c|c|c|c|c|c|c|}
\hline & $\log \mathrm{Pb}$ & $\log \mathrm{Sb}$ & $\mathrm{Sc}$ & $\log \mathrm{Sr}$ & Log Th & $\mathrm{U}$ & $\mathrm{V}$ & $\log Y$ & $\log \mathrm{Yb}$ & $\log \mathrm{Zn}$ & $\log \mathrm{Zr}$ \\
\hline $\mathrm{SiO} 2$ & -.038 & -.226 & -.848 & -.180 & -.737 & -.676 & -.776 & -.328 & -.499 & -.206 & -.532 \\
\hline $\mathrm{Al} 2 \mathrm{O} 3$ & .019 & .157 & .776 & .199 & .695 & .604 & .695 & .273 & .454 & .123 & .423 \\
\hline Log FeTO3 & .030 & .228 & .350 & -.220 & .301 & .427 & .371 & .142 & .143 & .300 & .392 \\
\hline $\log \mathrm{MgO}$ & -.071 & .250 & .661 & .131 & .528 & .583 & .575 & .395 & .508 & .233 & .308 \\
\hline $\log \mathrm{CaO}$ & .253 & .266 & .350 & .697 & .308 & .335 & .246 & .635 & .651 & .156 & .082 \\
\hline $\mathrm{Na} 2 \mathrm{O}$ & .274 & .097 & -.162 & .662 & -.042 & -.036 & -.190 & .293 & .257 & -.006 & -.012 \\
\hline $\mathrm{K} 2 \mathrm{O}$ & -.231 & -.056 & .529 & -.266 & .443 & .332 & .502 & -.020 & .083 & -.086 & .342 \\
\hline $\mathrm{TiO} 2$ & .068 & .253 & .923 & .254 & .646 & .618 & .895 & .358 & .490 & .259 & .527 \\
\hline $\mathrm{P} 2 \mathrm{O} 5$ & .207 & .462 & .572 & .188 & .360 & .457 & .445 & .478 & .542 & .167 & .377 \\
\hline LOI & .073 & .299 & .676 & -.000 & .521 & .555 & .606 & .187 & .320 & .300 & .280 \\
\hline Log As & .354 & .498 & .306 & .078 & .070 & .247 & .315 & .075 & .143 & .327 & -.049 \\
\hline $\log B$ & -.209 & .124 & .281 & .023 & .359 & .224 & .261 & .051 & .036 & -.217 & .156 \\
\hline $\log \mathrm{Ba}$ & -.022 & .024 & .436 & -.034 & .332 & .351 & .443 & .120 & .195 & .107 & .263 \\
\hline $\mathrm{Be}$ & -.054 & .018 & .695 & .153 & .642 & .518 & .632 & .313 & .439 & .159 & .372 \\
\hline $\log \mathrm{Ce}$ & .245 & .218 & .078 & .357 & .238 & .361 & .003 & .551 & .311 & .278 & .187 \\
\hline Log Co & .195 & .243 & .442 & .180 & .393 & .510 & .421 & .305 & .328 & .446 & .333 \\
\hline $\mathrm{Cr}$ & .104 & .176 & .781 & .244 & .470 & .429 & .887 & .173 & .328 & .226 & .393 \\
\hline $\log \mathrm{Cu}$ & .440 & .057 & -.040 & .188 & .054 & .131 & .028 & .084 & .060 & .373 & -.011 \\
\hline $\log \mathrm{Ga}$ & -.029 & .152 & .799 & .123 & .708 & .589 & .725 & .229 & .374 & .167 & .460 \\
\hline $\mathrm{La}$ & .234 & .205 & .102 & .359 & .343 & .398 & .041 & .523 & .307 & .234 & .249 \\
\hline $\log \mathrm{Li}$ & .132 & .228 & 660 & .282 & .629 & .661 & .580 & .411 & .477 & .410 & .320 \\
\hline $\log \mathrm{Mn}$ & .483 & .299 & .317 & .456 & .241 & .356 & .243 & .589 & .584 & .730 & .185 \\
\hline $\mathrm{Nd}$ & .149 & .192 & .145 & .336 & .361 & .401 & .068 & .541 & .325 & .190 & .251 \\
\hline $\mathrm{Ni}$ & .092 & .272 & .710 & .321 & .414 & .512 & .702 & .400 & .489 & .373 & .220 \\
\hline $\log \mathrm{Pb}$ & 1.000 & .421 & .015 & .316 & .042 & .228 & .073 & .295 & .237 & .586 & .154 \\
\hline $\log \mathrm{Sb}$ & .421 & 1.000 & .248 & .082 & .069 & .368 & .216 & .329 & .306 & .289 & .185 \\
\hline $\mathrm{Sc}$ & .015 & .248 & 1.000 & .151 & .583 & .580 & .916 & .264 & .439 & .234 & .443 \\
\hline $\log \mathrm{Sr}$ & .316 & .082 & .151 & 1.000 & .220 & .254 & .113 & .603 & .569 & .273 & .038 \\
\hline Log Th & .042 & .069 & .583 & .220 & 1.000 & .670 & .527 & .333 & .351 & .172 & .663 \\
\hline $\mathrm{U}$ & .228 & .368 & .580 & .254 & 670 & 1.000 & .514 & .469 & .496 & .348 & .571 \\
\hline V & .073 & .216 & .916 & .113 & .527 & .514 & 1.000 & .152 & .324 & .239 & .414 \\
\hline $\log Y$ & .295 & .329 & .264 & .603 & .333 & .469 & .152 & 1.000 & .853 & .373 & .270 \\
\hline $\log \mathrm{Yb}$ & .237 & .306 & .439 & .569 & .351 & .496 & .324 & .853 & 1.000 & .389 & .242 \\
\hline $\log \mathrm{Zn}$ & .586 & .289 & .234 & .273 & .172 & .348 & .239 & .373 & .389 & 1.000 & .194 \\
\hline $\log \mathrm{Zr}$ & .154 & .185 & .443 & .038 & .663 & .571 & .414 & .270 & .242 & .194 & 1.000 \\
\hline
\end{tabular}

Appendix Table 2.--Correlation matrix (25X25) for 128 samples (24 sandstones, 78 siltites, 2 argillites, and 24 diamictites) of the Big Creek and Apple Creek Formations, Lemhi Range, Idaho. Coefficients reflect replacement of "less than" values in Table 10. $\mathrm{Fe}_{\mathrm{T}} \mathrm{O}_{3}$, total iron as $\mathrm{Fe}_{2} \mathrm{O}_{3}$; LOI, loss on ignition.

\begin{tabular}{|c|c|c|c|c|c|c|c|c|c|c|c|}
\hline & $\mathrm{SiO} 2$ & $\mathrm{~A} 12 \mathrm{O} 3$ & $\begin{array}{l}\text { Log } \\
\text { FeTO3 } \\
\end{array}$ & $\begin{array}{l}\mathrm{Log} \\
\mathrm{MgO}\end{array}$ & $\begin{array}{l}\mathrm{Log} \\
\mathrm{CaO} \\
\end{array}$ & $\begin{array}{l}\mathrm{Log} \\
\mathrm{Na} 2 \mathrm{O}\end{array}$ & $\mathrm{K} 2 \mathrm{O}$ & $\begin{array}{l}\mathrm{Log} \\
\mathrm{TiO} 2 \\
\end{array}$ & $\begin{array}{l}\mathrm{Log} \\
\mathrm{P} 2 \mathrm{O} 5 \\
\end{array}$ & $\begin{array}{l}\mathrm{Log} \\
\mathrm{MnO}\end{array}$ & $\begin{array}{l}\text { Log } \\
\text { LOI }\end{array}$ \\
\hline $\mathrm{SiO} 2$ & 1.000 & -.823 & -.746 & -.348 & .063 & -.097 & -.736 & -.776 & -.416 & .051 & -.401 \\
\hline $\mathrm{Al} 2 \mathrm{O} 3$ & -.823 & 1.000 & .336 & .399 & .068 & .245 & .785 & .760 & .396 & -.080 & .344 \\
\hline LogFeTO3 & -.746 & .336 & 1.000 & .177 & -.370 & -.115 & .392 & .537 & .318 & -.071 & .209 \\
\hline $\log \mathrm{MgO}$ & -.348 & .399 & .177 & 1.000 & -.058 & .005 & .264 & .295 & .116 & -.159 & .451 \\
\hline $\log \mathrm{CaO}$ & .063 & .068 & -.370 & -.058 & 1.000 & .449 & -.170 & .148 & .313 & .502 & .134 \\
\hline $\log \mathrm{Na} 2 \mathrm{O}$ & -.097 & .245 & -.115 & .005 & .449 & 1.000 & -.264 & .260 & .241 & .209 & -.332 \\
\hline $\mathrm{K} 2 \mathrm{O}$ & -.736 & .785 & .392 & .264 & -.170 & -.264 & 1.000 & .553 & .168 & -.147 & .421 \\
\hline Log $\mathrm{TiO}_{2}$ & -.776 & .760 & .537 & .295 & .148 & .260 & .553 & 1.000 & .714 & -.025 & .343 \\
\hline Log P2O5 & -.416 & .396 & .318 & .116 & .313 & .241 & .168 & .714 & 1.000 & .091 & .339 \\
\hline $\log \mathrm{MnO}$ & .051 & -.080 & -.071 & -.159 & .502 & .209 & -.147 & -.025 & .091 & 1.000 & .074 \\
\hline Log LOI & -.401 & .344 & .209 & .451 & .134 & -.332 & .421 & .343 & .339 & .074 & 1.000 \\
\hline $\log B$ & -.378 & .309 & .342 & .225 & -.011 & -.245 & .383 & .491 & .424 & .091 & .482 \\
\hline $\log B a$ & -.527 & .297 & .608 & -.003 & -.287 & -.152 & .504 & .332 & .043 & .114 & .098 \\
\hline $\log \mathrm{Be}$ & -.408 & .419 & .263 & .259 & -.087 & -.175 & .503 & .264 & -.017 & .078 & .337 \\
\hline Log Co & -.294 & .194 & .339 & .343 & -.164 & .051 & .122 & .184 & .062 & .125 & .143 \\
\hline $\log \mathrm{Cr}$ & -.423 & .491 & .174 & .271 & .260 & .122 & .330 & .654 & .556 & .028 & .280 \\
\hline $\log \mathrm{Cu}$ & -.325 & .142 & .422 & .075 & -.255 & -.078 & .226 & .150 & .164 & .089 & .146 \\
\hline $\log \mathrm{Ga}$ & -.714 & .674 & .463 & .217 & -.051 & .090 & .612 & .581 & .301 & -.009 & .249 \\
\hline $\log \mathrm{La}$ & -.283 & .332 & .150 & .060 & .074 & -.049 & .347 & .345 & .300 & .080 & .242 \\
\hline
\end{tabular}




\begin{tabular}{|c|c|c|c|c|c|c|c|c|c|c|c|}
\hline $\log \mathrm{Ni}$ & -.426 & .407 & .315 & .602 & .148 & .133 & .274 & .451 & .356 & .025 & .386 \\
\hline $\log \mathrm{Pb}$ & -.237 & .180 & .183 & -.085 & -.123 & .074 & .155 & .143 & .158 & .086 & .023 \\
\hline $\log \mathrm{Sc}$ & -.697 & .737 & .391 & .184 & .046 & .138 & .653 & .704 & .463 & .112 & .311 \\
\hline $\log V$ & -.600 & .538 & .447 & .188 & .090 & .144 & .409 & .670 & .527 & .092 & .323 \\
\hline $\log \mathrm{Y}$ & -.263 & .250 & .195 & .032 & .072 & .061 & .278 & .356 & .304 & .100 & .157 \\
\hline \multirow[t]{2}{*}{$\log \mathrm{Zr}$} & -.297 & .283 & .253 & .150 & .100 & .025 & .253 & .532 & .435 & -.016 & .239 \\
\hline & $\log B$ & $\log \mathrm{Ba}$ & $\log B$ & Log Co & $\log \mathrm{Cr}$ & $\log \mathrm{Cu}$ & $\log \mathrm{Ga}$ & $\log \mathrm{La}$ & $\log \mathrm{Ni}$ & $\log \mathrm{Pb}$ & $\log \mathrm{Sc}$ \\
\hline $\mathrm{SiO} 2$ & -.378 & -.527 & -.408 & -.294 & -.423 & -.325 & -.714 & -.283 & -.426 & -.237 & -.697 \\
\hline $\mathrm{Al} 2 \mathrm{O} 3$ & .309 & .297 & .419 & .194 & .491 & .142 & .674 & .332 & .407 & .180 & .737 \\
\hline LogFeTO3 & .342 & .608 & .263 & .339 & .174 & .422 & .463 & .150 & .315 & .183 & .391 \\
\hline $\log \mathrm{MgO}$ & .225 & -.003 & .259 & .343 & .271 & .075 & .217 & .060 & .602 & -.085 & .184 \\
\hline $\log \mathrm{CaO}$ & -.011 & -.287 & -.087 & -.164 & .260 & -.255 & -.051 & .074 & .148 & -.123 & .046 \\
\hline Log $\mathrm{Na} 2 \mathrm{O}$ & -.245 & -.152 & -.175 & .051 & .122 & -.078 & .090 & -.049 & .133 & .074 & .138 \\
\hline $\mathrm{K} 2 \mathrm{O}$ & .383 & .504 & .503 & .122 & .330 & .226 & .612 & .347 & .274 & .155 & .653 \\
\hline $\log \mathrm{TiO}_{2}$ & .491 & .332 & .264 & .184 & .654 & .150 & .581 & .345 & .451 & .143 & .704 \\
\hline Log P2O5 & .424 & .043 & -.017 & .062 & .556 & .164 & .301 & .300 & .356 & .158 & .463 \\
\hline $\log \mathrm{MnO}$ & .091 & .114 & .078 & .125 & .028 & .089 & -.009 & .080 & .025 & .086 & .112 \\
\hline Log LOI & .482 & .098 & .337 & .143 & .280 & .146 & .249 & .242 & .386 & .023 & .311 \\
\hline $\log B$ & 1.000 & .399 & .479 & .029 & .458 & -.022 & .405 & .309 & .286 & .090 & .522 \\
\hline $\log B a$ & .399 & 1.000 & .541 & .267 & .060 & .343 & .455 & .189 & .156 & .137 & .475 \\
\hline $\log B e$ & .479 & .541 & 1.000 & .082 & .154 & .116 & .508 & .099 & .237 & -.017 & .467 \\
\hline Log Co & .029 & .267 & .082 & 1.000 & -.005 & .337 & .114 & .078 & .469 & .050 & .108 \\
\hline $\log \mathrm{Cr}$ & .458 & .060 & .154 & -.005 & 1.000 & -.006 & .556 & .314 & .398 & .116 & .524 \\
\hline $\log \mathrm{Cu}$ & -.022 & .343 & .116 & .337 & -.006 & 1.000 & .135 & .034 & .180 & .235 & .122 \\
\hline $\log \mathrm{Ga}$ & .405 & .455 & .508 & .114 & .556 & .135 & 1.000 & .308 & .342 & .264 & .648 \\
\hline $\log \mathrm{La}$ & .309 & .189 & .099 & .078 & .314 & .034 & .308 & 1.000 & .159 & .257 & .393 \\
\hline $\log \mathrm{Ni}$ & .286 & .156 & .237 & .469 & .398 & .180 & .342 & .159 & 1.000 & -.068 & .234 \\
\hline $\log \mathrm{Pb}$ & .090 & .137 & -.017 & .050 & .116 & .235 & .264 & .257 & -.068 & 1.000 & .260 \\
\hline Log Sc & .522 & .475 & .467 & .108 & .524 & .122 & .648 & .393 & .234 & .260 & 1.000 \\
\hline Log V & .610 & .409 & .425 & .092 & .627 & .114 & .663 & .362 & .372 & .229 & .754 \\
\hline $\log \mathrm{Y}$ & .457 & .290 & .227 & .101 & .229 & .028 & .409 & .322 & .220 & .084 & .431 \\
\hline \multirow[t]{27}{*}{$\log \mathrm{Zr}$} & .573 & .300 & .299 & .021 & .543 & -.077 & .498 & .310 & .250 & -.033 & .421 \\
\hline & & & & & $\log \mathrm{V}$ & $\log Y$ & $\log \mathrm{Zr}$ & & & & \\
\hline & & & & $\mathrm{SiO} 2$ & -.600 & -.263 & -.297 & & & & \\
\hline & & & & $\mathrm{Al} 2 \mathrm{O} 3$ & .538 & .250 & .283 & & & & \\
\hline & & & & LogFeTO3 & .447 & .195 & .253 & & & & \\
\hline & & & & $\log \mathrm{MgO}$ & .188 & .032 & .150 & & & & \\
\hline & & & & $\log \mathrm{CaO}$ & .090 & .072 & .100 & & & & \\
\hline & & & & $\log \mathrm{Na} 2 \mathrm{O}$ & .144 & .061 & .025 & & & & \\
\hline & & & & $\mathrm{K} 2 \mathrm{O}$ & .409 & .278 & .253 & & & & \\
\hline & & & & $\log \mathrm{TiO}_{2}$ & .670 & .356 & .532 & & & & \\
\hline & & & & Log P2O5 & .527 & .304 & .435 & & & & \\
\hline & & & & Log $\mathrm{MnO}$ & .092 & .100 & -.016 & & & & \\
\hline & & & & Log LOI & .323 & .157 & .239 & & & & \\
\hline & & & & $\log B$ & .610 & .457 & .573 & & & & \\
\hline & & & & $\log \mathrm{Ba}$ & .409 & .290 & .300 & & & & \\
\hline & & & & Log Be & .425 & .227 & .299 & & & & \\
\hline & & & & Log Co & .092 & .101 & .021 & & & & \\
\hline & & & & $\log \mathrm{Cr}$ & .627 & .229 & .543 & & & & \\
\hline & & & & $\log \mathrm{Cu}$ & .114 & .028 & -.077 & & & & \\
\hline & & & & $\log \mathrm{Ga}$ & .663 & .409 & .498 & & & & \\
\hline & & & & $\log \mathrm{La}$ & .362 & .322 & .310 & & & & \\
\hline & & & & $\log \mathrm{Ni}$ & .372 & .220 & .250 & & & & \\
\hline & & & & $\log \mathrm{Pb}$ & .229 & .084 & -.033 & & & & \\
\hline & & & & $\operatorname{Log~Sc}$ & .754 & .431 & .421 & & & & \\
\hline & & & & $\log \mathrm{V}$ & 1.000 & .371 & .519 & & & & \\
\hline & & & & $\log Y$ & .371 & 1.000 & .505 & & & & \\
\hline & & & & $\log \mathrm{Zr}$ & .519 & .505 & 1.000 & & & & \\
\hline
\end{tabular}




\section{APPENDIX--FACTOR ANALYSIS OF LOG-RATIO DATA, SALMON RIVER MOUNTAINS}

As discussed under "R-mode factor analysis, Salmon River Mountains," the application of R-mode factor analysis to raw compositional data that sum to 100 percent may not be appropriate. In addition to previously-listed precautions taken in interpreting factor analysis of raw compositional data, the method of log-contrast principal components analysis (Reyment and Savazzi, 1999), followed by rotation of principal components and factor interpretation (Cooley and Lohnes, 1962), was employed. The method and results are discussed here.

A log-contrast principal components analysis can be conducted using the DOS program "pcaconst" (Reyment and Savazzi, 1999), which transforms raw data into log-ratios, computes the covariance and correlation matrices from log ratios, and computes the principal components of the new matrices. To calculate log-ratios, each cell of a row is divided by the geometric mean of that row and the result is converted to its logarithm. A new covariance matrix, termed the "centered log-ratio covariance matrix," is calculated from the log-ratio matrix, and a corresponding centered log-ratio correlation matrix is computed. The new correlation matrix is a measure of proportionality between the original variables (columns). Raw data may be expressed either as "percent," "parts per million," or both, if consistent within columns. Finally, the program "pcaconst" performs a principal components analysis of both the centered log-ratio correlation matrix and the correlation matrix computed from raw data.

Correlation coefficients calculated by the two methods are not comparable, but the results of the principal components analysis (roots, latent vectors, and factor loadings) can be inspected

for similarities and differences. For the present experiment, correlation coefficients generated by the program "pcaconst" are presented as a record of input for further analysis (Appendix Tables A3 and A4). The program "pcaconst" was found to be limited to matrices of 20 columns. Therefore, the original 98X36 Salmon River data matrix was trimmed to 98X20. Columns (oxides and elements) were retained based on their relevance to the original factor interpretation. To permit direct comparison of the log-contrast and traditional methods of principal components analysis, no logarithmic transformations were made on any of the columns prior to calculation of $\log$ ratios, although frequency distributions for some (e.g., $\mathrm{CaO})$ are clearly skewed.

Both pcaconst and the software used here (StatView, by SAS Institute Inc., 1998) perform a simple principal components analysis, but the latter program includes a complete, interactive factor analysis. The centered log-ratio and raw-data correlation matrices from pcaconst were analyzed with StatView (Appendix tables A5-A7). Factor interpretations are compared with the original principal component interpretation in Appendix table A8. Comparisons are limited to the first four factors in each case.

The first four eigenvalues and variance proportions of the two matrices are comparable in magnitude (Appendix Table A5). Coefficients of the first latent vectors (not shown) of each matrix are also similar, but the coefficients of other vectors diverge widely. In both analyses, the first four principal components account for a sufficient proportion of variance to warrant consideration of a four-component system for interpretation (Appendix Table A6). Upon rotation by the Varimax method, oxide and element loadings on the first four principal components permit comparable but not identical interpretations (Appendix Table A7).

The principal differences between interpretation of the rotated log-contrast principal components and the rotated principal components based on the raw data involve factors 1 and 4. Factor 1 of both interpretations appears to involve high loadings of oxides and elements residing in micas and chlorite, and thus is readily interpreted as the effect of grain size. However, $\mathrm{Cu}$ and $\mathrm{Pb}$ have large negative loadings on factor 1 as determined by the log-contrast method; this makes no genetic sense unless one were to conclude that mineralization is inversely related to grain size, i.e., concentrated in fine-grained rocks. Although such a relationship is possible, further investigation is required to verify it. Even when as many as eight principal components are preserved for rotation, $\mathrm{Cu}$ never leaves factor 1 . In the principal components analysis of the raw data, and in the original analysis of the $98 \times 36$ data matrix, $\mathrm{Pb}$ and $\mathrm{Zn}$ appear in factor 4 and $\mathrm{Cu}$ is unique; both observations are interpreted as effects of mineralization. In the log-contrast 
method, a genetically different factor 4 evidently represents potassium silicates (micas and Kfeldspar).

Factors 2 (rare earths) and 3 (plagioclase) are essentially identical in both analyses, except for the appearance of two additional elements with loadings of opposite sign in factor 3 $(\mathrm{Cr}$ and $\mathrm{V})$ and factor $3\left(\mathrm{Fe}_{\mathrm{T}} \mathrm{O}_{3}\right.$ and $\left.\mathrm{Zn}\right)$ of the log-ratio analysis.

Problems with interpreting the results of the log-contrast principal components analysis stem from its basis in complex ratios. Although petrologists frequently try to interpret complex ratios (at their own risk), they have little experience interpreting the ratios of chemical values for individual elements to the geometric mean of all elements determined for a sample. The value of any ratio varies as its numerator or denominator, or both. If the numerators (individual cells or values) are affected by one factor, the value of the log-ratio varies. If the denominators (row geometric means) are affected by a group of cells, such as those representing another factor, then the value of the log-ratio also varies. Thus, interpretation is not straight-forward. In the present case, interpretation has relied primarily on knowledge of the numerator of the log-ratio, but clearly something in the denominator is affecting the factor analysis. A look at correlations between the original, raw oxides and elements (numerators) and the row geometric means (denominators) reveals that the two are not independent, and thus interpretation becomes complicated (Appendix Table A9).

Our original approach is confirmed: analyze and compare different data sets, use a variety of statistical techniques, and use other relevant information for interpretion. Log-contrast principal components analysis offers another way to test conclusions, but it has its pitfalls. 
Appendix Table 3.--Matrix (20X20) of centered log-ratio correlation coefficients, ouput from program "pcaconst" (Reyment and Savazzi, 1999), Salmon River Mountains data set.

$\mathrm{Fe}_{\mathrm{T}} \mathrm{O}_{3}$, total iron as $\mathrm{Fe}_{2} \mathrm{O}_{3}$.

\begin{tabular}{lcccccccccc}
\hline & $\mathrm{SiO}_{2}$ & $\mathrm{Al}_{2} \mathrm{O}_{3}$ & $\mathrm{Fe}_{\mathrm{T}} \mathrm{O}_{3}$ & $\mathrm{MgO}$ & $\mathrm{CaO}$ & $\mathrm{Na}_{2} \mathrm{O}$ & $\mathrm{K}_{2} \mathrm{O}$ & $\mathrm{TiO}_{2}$ & $\mathrm{Ce}$ & $\mathrm{CO}$ \\
\hline $\mathrm{SiO}_{2}$ & 1.000 & .605 & .371 & .086 & -.385 & .075 & .450 & .176 & -.035 & -.113 \\
$\mathrm{Al}_{2} \mathrm{O}_{3}$ & .605 & 1.000 & .336 & .412 & -.264 & -.002 & .792 & .660 & -.362 & .021 \\
$\mathrm{Fe}_{\mathrm{T}} \mathrm{O}_{3}$ & .371 & .336 & 1.000 & .409 & -.496 & -.363 & .411 & .333 & -.085 & .405 \\
$\mathrm{MgO}$ & .086 & .412 & .409 & 1.000 & -.063 & -.172 & .427 & .452 & -.214 & .272 \\
$\mathrm{CaO}$ & -.385 & -.264 & -.496 & -.063 & 1.000 & .412 & -.463 & -.155 & -.016 & -.157 \\
$\mathrm{Na}_{2} \mathrm{O}$ & .075 & -.002 & -.363 & -.172 & .412 & 1.000 & -.347 & -.130 & -.026 & -.244 \\
$\mathrm{~K}_{2} \mathrm{O}$ & .450 & .792 & .411 & .427 & -.463 & -.347 & 1.000 & .609 & -.194 & .064 \\
$\mathrm{TiO}$ & .176 & .660 & .333 & .452 & -.155 & -.130 & .609 & 1.000 & -.457 & .039 \\
$\mathrm{Ce}$ & -.035 & -.362 & -.085 & -.214 & -.016 & -.026 & -.194 & -.457 & 1.000 & -.213 \\
$\mathrm{Co}$ & -.113 & .021 & .405 & .272 & -.157 & -.244 & .064 & .039 & -.213 & 1.000 \\
$\mathrm{Cr}$ & .138 & .354 & .126 & .214 & -.218 & -.107 & .383 & .740 & -.476 & -.002 \\
$\mathrm{Cu}$ & -.220 & -.446 & -.196 & -.482 & -.137 & -.011 & -.429 & -.498 & -.062 & -.087 \\
$\mathrm{La}$ & -.111 & -.386 & -.210 & -.212 & .068 & .006 & -.241 & -.463 & .977 & -.262 \\
$\mathrm{Nd}$ & -.056 & -.302 & -.157 & -.087 & .069 & .008 & -.173 & -.388 & .944 & -.227 \\
$\mathrm{Ni}$ & -.108 & .118 & .177 & .570 & -.007 & -.293 & .302 & .473 & -.247 & .150 \\
$\mathrm{~Pb}$ & -.068 & -.313 & -.215 & -.498 & -.046 & -.058 & -.300 & -.419 & -.070 & -.156 \\
$\mathrm{Sc}$ & -.049 & .584 & .185 & .426 & -.122 & -.237 & .573 & .839 & -.441 & .094 \\
$\mathrm{Sr}$ & .054 & -.081 & -.502 & -.283 & .470 & .589 & -.286 & -.219 & .005 & -.284 \\
$\mathrm{~V}$ & .065 & .551 & .266 & .393 & -.262 & -.285 & .604 & .858 & -.500 & .097 \\
$\mathrm{Zn}$ & -.313 & -.424 & -.050 & -.215 & -.199 & -.457 & -.272 & -.316 & -.100 & .132 \\
\hline
\end{tabular}

\begin{tabular}{lcccccccccc}
\hline & $\mathrm{Cr}$ & $\mathrm{Cu}$ & $\mathrm{La}$ & $\mathrm{Nd}$ & $\mathrm{Ni}$ & $\mathrm{Pb}$ & $\mathrm{Sc}$ & $\mathrm{Sr}$ & $\mathrm{V}$ & $\mathrm{Zn}$ \\
\hline $\mathrm{SiO}_{2}$ & .138 & -.220 & -.111 & -.056 & -.108 & -.068 & -.049 & .054 & .065 & -.313 \\
$\mathrm{Al}_{2} \mathrm{O}_{3}$ & .354 & -.446 & -.386 & -.302 & .118 & -.313 & .584 & -.081 & .551 & -.424 \\
$\mathrm{Fe}_{\mathrm{T}} \mathrm{O}_{3}$ & .126 & -.196 & -.210 & -.157 & .177 & -.215 & .185 & -.502 & .266 & -.050 \\
$\mathrm{MgO}$ & .214 & -.482 & -.212 & -.087 & .570 & -.498 & .426 & -.283 & .393 & -.215 \\
$\mathrm{CaO}$ & -.218 & -.137 & .068 & .069 & -.007 & -.046 & -.122 & .470 & -.262 & -.199 \\
$\mathrm{Na}_{2} \mathrm{O}$ & -.107 & -.011 & .006 & .008 & -.293 & -.058 & -.237 & .589 & -.285 & -.457 \\
$\mathrm{~K}_{2} \mathrm{O}$ & .383 & -.429 & -.241 & -.173 & .302 & -.300 & .573 & -.286 & .604 & -.272 \\
$\mathrm{TiO}$ & .740 & -.498 & -.463 & -.388 & .473 & -.419 & .839 & -.219 & .858 & -.316 \\
$\mathrm{Ce}$ & -.476 & -.062 & .977 & .944 & -.247 & -.070 & -.441 & .005 & -.500 & -.100 \\
$\mathrm{Co}$ & -.002 & -.087 & -.262 & -.227 & .150 & -.156 & .094 & -.284 & .097 & .132 \\
$\mathrm{Cr}$ & 1.000 & -.310 & -.464 & -.444 & .551 & -.275 & .682 & -.157 & .844 & -.188 \\
$\mathrm{Cu}$ & -.310 & 1.000 & -.071 & -.148 & -.421 & .283 & -.423 & -.136 & -.381 & .200 \\
$\mathrm{La}$ & -.464 & -.071 & 1.000 & .962 & -.219 & -.073 & -.427 & .066 & -.502 & -.095 \\
$\mathrm{Nd}$ & -.444 & -.148 & .962 & 1.000 & -.142 & -.189 & -.388 & .047 & -.457 & -.141 \\
$\mathrm{Ni}$ & .551 & -.421 & -.219 & -.142 & 1.000 & -.452 & .474 & -.210 & .510 & -.055 \\
$\mathrm{~Pb}$ & -.275 & .283 & -.073 & -.189 & -.452 & 1.000 & -.372 & .023 & -.325 & .419 \\
$\mathrm{SC}$ & .682 & -.423 & -.427 & -.388 & .474 & -.372 & 1.000 & -.314 & .897 & -.213 \\
$\mathrm{Sr}$ & -.157 & -.136 & .066 & .047 & -.210 & .023 & -.314 & 1.000 & -.320 & -.138 \\
$\mathrm{~V}$ & .844 & -.381 & -.502 & -.457 & .510 & -.325 & .897 & -.320 & 1.000 & -.195 \\
$\mathrm{Zn}$ & -.188 & .200 & -.095 & -.141 & -.055 & .419 & -.213 & -.138 & -.195 & 1.000 \\
\hline
\end{tabular}


Appendix Table 4.--Raw 20X20 R-matrix, crude equivalent of Table 3), calculated from untransformed data, Salmon River Mountains data set. $\mathrm{Fe}_{\mathrm{T}} \mathrm{O}_{3}$, total iron as $\mathrm{Fe}_{2} \mathrm{O}_{3}$.

\begin{tabular}{lcccccccccc}
\hline & $\mathrm{SiO}_{2}$ & $\mathrm{Al}_{2} \mathrm{O}_{3}$ & $\mathrm{Fe}_{\mathrm{T}} \mathrm{O}_{3}$ & $\mathrm{MgO}$ & $\mathrm{CaO}$ & $\mathrm{Na}_{2} \mathrm{O}$ & $\mathrm{K}_{2} \mathrm{O}$ & $\mathrm{TiO}_{2}$ & $\mathrm{Ce}$ \\
\hline $\mathrm{SiO}_{2}$ & 1.000 & -.941 & -.346 & -.676 & -.300 & .128 & -.651 & -.810 & -.067 & -.343 \\
$\mathrm{Al}_{2} \mathrm{O}_{3}$ & -.941 & 1.000 & .118 & .530 & .189 & -.076 & .647 & .712 & -.024 & .230 \\
$\mathrm{Fe}_{\mathrm{T}} \mathrm{O}_{3}$ & -.346 & .118 & 1.000 & .354 & .009 & -.259 & .148 & .356 & .196 & .442 \\
$\mathrm{MgO}$ & -.676 & .530 & .354 & 1.000 & .235 & -.176 & .386 & .624 & .150 & .337 \\
$\mathrm{CaO}$ & -.300 & .189 & .009 & .235 & 1.000 & .281 & -.152 & .325 & .185 & .146 \\
$\mathrm{Na}_{2} \mathrm{O}$ & .128 & -.076 & -.259 & -.176 & .281 & 1.000 & -.585 & -.035 & .129 & .002 \\
$\mathrm{~K}_{2} \mathrm{O}$ & -.651 & .647 & .148 & .386 & -.152 & -.585 & 1.000 & .403 & -.113 & .014 \\
$\mathrm{TiO}$ & -.810 & .712 & .356 & .624 & .325 & -.035 & .403 & 1.000 & .120 & .284 \\
$\mathrm{Ce}$ & -.067 & -.024 & .196 & .150 & .185 & .129 & -.113 & .120 & 1.000 & .064 \\
$\mathrm{Co}$ & -.343 & .230 & .442 & .337 & .146 & .002 & .014 & .284 & .064 & 1.000 \\
$\mathrm{Cr}$ & -.618 & .521 & .162 & .469 & .278 & .008 & .297 & .798 & .066 & .232 \\
$\mathrm{Cu}$ & -.044 & .033 & .011 & .115 & .043 & .158 & -.094 & .043 & .075 & .180 \\
$\mathrm{La}$ & -.144 & .076 & .083 & .203 & .260 & .198 & -.104 & .189 & .962 & .070 \\
$\mathrm{Nd}$ & -.192 & .127 & .076 & .261 & .255 & .162 & -.035 & .222 & .939 & .047 \\
$\mathrm{Ni}$ & -.610 & .464 & .253 & .653 & .439 & -.027 & .220 & .699 & .267 & .367 \\
$\mathrm{~Pb}$ & .071 & -.097 & .040 & -.102 & .077 & -.044 & -.150 & -.044 & .046 & .050 \\
$\mathrm{SC}$ & -.848 & .776 & .286 & .625 & .284 & -.162 & .529 & .923 & .029 & .303 \\
$\mathrm{Sr}$ & -.109 & .115 & -.248 & .027 & .590 & .615 & -.342 & .196 & .216 & .060 \\
$\mathrm{~V}$ & -.776 & .695 & .313 & .545 & .219 & -.190 & .502 & .895 & -.022 & .266 \\
$\mathrm{Zn}$ & -.143 & .067 & .177 & .134 & .210 & -.063 & -.092 & .192 & .084 & .210 \\
\hline
\end{tabular}

\begin{tabular}{lccccccccccc}
\hline & $\mathrm{Cr}$ & $\mathrm{Cu}$ & $\mathrm{La}$ & $\mathrm{Nd}$ & $\mathrm{Ni}$ & $\mathrm{Pb}$ & $\mathrm{Sc}$ & $\mathrm{Sr}$ & $\mathrm{V}$ & $\mathrm{Zn}$ \\
\hline $\mathrm{SiO}_{2}$ & -.618 & -.044 & -.144 & -.192 & -.610 & .071 & -.848 & -.109 & -.776 & -.143 \\
$\mathrm{Al}_{2} \mathrm{O}_{3}$ & .521 & .033 & .076 & .127 & .464 & -.097 & .776 & .115 & .695 & .067 \\
$\mathrm{Fe}_{\mathrm{T}} \mathrm{O}_{3}$ & .162 & .011 & .083 & .076 & .253 & .040 & .286 & -.248 & .313 & .177 \\
$\mathrm{MgO}$ & .469 & .115 & .203 & .261 & .653 & -.102 & .625 & .027 & .545 & .134 \\
$\mathrm{CaO}$ & .278 & .043 & .260 & .255 & .439 & .077 & .284 & .590 & .219 & .210 \\
$\mathrm{Na}_{2} \mathrm{O}$ & .008 & .158 & .198 & .162 & -.027 & -.044 & -.162 & .615 & -.190 & -.063 \\
$\mathrm{~K}_{2} \mathrm{O}$ & .297 & -.094 & -.104 & -.035 & .220 & -.150 & .529 & -.342 & .502 & -.092 \\
$\mathrm{TiO}$ & .798 & .043 & .189 & .222 & .699 & -.044 & .923 & .196 & .895 & .192 \\
$\mathrm{Ce}$ & .066 & .075 & .962 & .939 & .267 & .046 & .029 & .216 & -.022 & .084 \\
$\mathrm{Co}$ & .232 & .180 & .070 & .047 & .367 & .050 & .303 & .060 & .266 & .210 \\
$\mathrm{Cr}$ & 1.000 & .033 & .154 & .150 & .743 & -.029 & .781 & .232 & .887 & .171 \\
$\mathrm{Cu}$ & .033 & 1.000 & .120 & .115 & .127 & .053 & .034 & .058 & .032 & .127 \\
$\mathrm{La}$ & .154 & .120 & 1.000 & .978 & .353 & .057 & .102 & .326 & .041 & .134 \\
$\mathrm{Nd}$ & .150 & .115 & .978 & 1.000 & .362 & .009 & .145 & .301 & .068 & .097 \\
$\mathrm{Ni}$ & .743 & .127 & .353 & .362 & 1.000 & -.015 & .710 & .311 & .702 & .283 \\
$\mathrm{~Pb}$ & -.029 & .053 & .057 & .009 & -.015 & 1.000 & -.033 & .033 & -.007 & .715 \\
$\mathrm{SC}$ & .781 & .034 & .102 & .145 & .710 & -.033 & 1.000 & .093 & .916 & .187 \\
$\mathrm{Sr}$ & .232 & .058 & .326 & .301 & .311 & .033 & .093 & 1.000 & .080 \\
$\mathrm{~V}$ & .887 & .032 & .041 & .068 & .702 & -.007 & .916 & .080 & .158 \\
$\mathrm{Zn}$ & .171 & .127 & .134 & .097 & .283 & .715 & .187 & .158 & .199 & .199 \\
& & & & & & & & & 1.000 \\
\hline
\end{tabular}


Appendix Table 5.--Comparison of eigenvalues, principal components analysis of 20X20 matrix of centered log-ratio correlation coefficients versus raw correlation coefficients, Salmon River Mountains.

\begin{tabular}{l|cc|cc}
\hline \multirow{2}{*}{$\begin{array}{l}\text { Eigenvalue } \\
\text { rank }\end{array}$} & \multicolumn{2}{|c|}{$\begin{array}{c}\text { Log-ratio correlation } \\
\text { matrix }\end{array}$} & \multicolumn{2}{c}{ Raw correlation matrix } \\
\cline { 2 - 5 } & Magnitude & $\begin{array}{c}\text { Variance } \\
\text { proportion }\end{array}$ & Magnitude & $\begin{array}{c}\text { Variance } \\
\text { proportion }\end{array}$ \\
\hline Value 1 & 6.767 & .338 & 6.941 & .347 \\
Value 2 & 2.888 & .144 & 3.460 & .173 \\
Value 3 & 2.585 & .129 & 1.997 & .100 \\
Value 4 & 1.978 & .099 & 1.827 & .091 \\
Value 5 & 1.371 & .069 & 1.253 & .063 \\
Value 6 & .938 & .047 & .976 & .049 \\
Value 7 & .717 & .036 & .795 & .040 \\
Value 8 & .633 & .032 & .667 & .033 \\
Value 9 & .535 & .027 & .519 & .026 \\
Value 10 & .391 & .020 & .450 & .023 \\
\hline
\end{tabular}

Appendix Table 6.--Comparison of communalities, 4-factor orthogonal solution, principal components analysis of 20X20 matrix of centered log-ratio correlation coefficients versus raw correlation coefficients, Salmon River Mountains. $\mathrm{h}^{2}$, communality; SMC, squared multiple correlation, the maximum expected communality for raw correlations. $\mathrm{Fe}_{\mathrm{T}} \mathrm{O}_{3}$, total iron as $\mathrm{Fe}_{2} \mathrm{O}_{3}$.

\begin{tabular}{l|c|cc}
\hline $\begin{array}{l}\text { Oxide } \\
\text { or } \\
\text { element }\end{array}$ & $\begin{array}{c}\text { Log-ratio } \\
\text { correlation } \\
\text { matrix }\end{array}$ & \multicolumn{2}{c}{$\begin{array}{c}\text { Raw } \\
\text { correlation } \\
\text { matrix }\end{array}$} \\
\cline { 2 - 4 } & $\mathrm{h}^{2}$ & $\mathrm{~h}^{2}$ & SMC \\
\hline $\mathrm{SiO}_{2}$ & .791 & .865 & .985 \\
$\mathrm{Al}_{2} \mathrm{O}_{3}$ & .859 & .725 & .973 \\
$\mathrm{Fe}_{\mathrm{T}} \mathrm{O}_{3}$ & .608 & .447 & .805 \\
$\mathrm{MgO}$ & .520 & .574 & .698 \\
$\mathrm{CaO}$ & .706 & .537 & .635 \\
$\mathrm{Na}_{2} \mathrm{O}$ & .718 & .703 & .704 \\
$\mathrm{~K}_{2} \mathrm{O}$ & .764 & .736 & .836 \\
$\mathrm{TiO}_{2}$ & .838 & .866 & .914 \\
$\mathrm{Ce}$ & .941 & .966 & .962 \\
$\mathrm{Co}$ & .267 & .283 & .389 \\
$\mathrm{Cr}$ & .636 & .711 & .902 \\
$\mathrm{Cu}$ & .543 & .078 & .135 \\
$\mathrm{La}$ & .938 & .972 & .983 \\
$\mathrm{Nd}$ & .953 & .960 & .969 \\
$\mathrm{Ni}$ & .677 & .731 & .786 \\
$\mathrm{~Pb}$ & .554 & .698 & .589 \\
$\mathrm{Sc}$ & .786 & .907 & .929 \\
$\mathrm{Sr}$ & .666 & .801 & .663 \\
$\mathrm{~V}$ & .837 & .871 & .950 \\
$\mathrm{Zn}$ & .615 & .794 & .646 \\
\hline
\end{tabular}

Appendix Table 7.--Comparison of factor loadings and interpretations, 4-factor orthogonal solution (Varimax rotation), principal components analysis of 20X20 matrix of centered log-ratio 
correlation coefficients versus raw correlation coefficients, Salmon River Mountains. $\mathrm{Fe}_{\mathrm{T}} \mathrm{O}_{3}$, total iron as $\mathrm{Fe}_{2} \mathrm{O}_{3}$. Bold type, factor loadings $>[0.50]$ (absolute value).

\begin{tabular}{|c|c|c|c|c|c|c|c|c|}
\hline \multirow{3}{*}{$\begin{array}{l}\text { Oxide } \\
\text { or } \\
\text { element }\end{array}$} & \multirow{2}{*}{\multicolumn{4}{|c|}{$\begin{array}{c}\text { Log-ratio correlation matrix } \\
\text { Factor }\end{array}$}} & \multirow{2}{*}{\multicolumn{4}{|c|}{$\frac{\text { Raw correlation matrix }}{\text { Factor }}$}} \\
\hline & & & & & & & & \\
\hline & 1 & 2 & 3 & 4 & 1 & 2 & 3 & 4 \\
\hline $\mathrm{SiO}_{2}$ & -.035 & .007 & -.077 & .885 & -.924 & -.073 & .077 & -.013 \\
\hline $\mathrm{Al}_{2} \mathrm{O}_{3}$ & .445 & 297 & -.051 & .755 & .843 & -.016 & -.032 & -.115 \\
\hline $\mathrm{Fe}_{\mathrm{T}} \mathrm{O}_{3}$ & .181 & .028 & .595 & .469 & .303 & .188 & -.440 & .355 \\
\hline $\mathrm{MgO}$ & .672 & .027 & .237 & .104 & .709 & .215 & -.131 & .089 \\
\hline $\mathrm{CaO}$ & .102 & -.034 & -.647 & -.526 & .322 & .151 & .608 & .201 \\
\hline $\mathrm{Na}_{2} \mathrm{O}$ & -.108 & .029 & -.838 & .056 & -.146 & .092 & .819 & -.055 \\
\hline $\mathrm{K}_{2} \mathrm{O}$ & .499 & .143 & .277 & .646 & .594 & -.074 & -.561 & -.253 \\
\hline $\mathrm{TiO}_{2}$ & .748 & .436 & .072 & .288 & .918 & .091 & .075 & .101 \\
\hline $\mathrm{Ce}$ & -.100 & -.965 & -.006 & -.007 & .003 & .978 & .047 & .078 \\
\hline Co & .087 & .149 & .476 & -.100 & .339 & .057 & -.043 & .404 \\
\hline $\mathrm{Cr}$ & .595 & .519 & .063 & .095 & .816 & .017 & .188 & .094 \\
\hline $\mathrm{Cu}$ & -.689 & .134 & .116 & -.191 & .034 & .103 & .126 & .224 \\
\hline $\mathrm{La}$ & -.068 & -.958 & -.079 & -.095 & .087 & .964 & .167 & .080 \\
\hline $\mathrm{Nd}$ & .033 & -.972 & -.075 & -.051 & .132 & .961 & .134 & .023 \\
\hline $\mathrm{Ni}$ & .736 & . 140 & .237 & -.242 & .757 & .267 & .188 & .228 \\
\hline $\mathrm{Pb}$ & -.710 & 201 & .059 & -.077 & -.141 & -.045 & -.012 & .822 \\
\hline Sc & .746 & .440 & .161 & .099 & .948 & .006 & -.023 & .083 \\
\hline $\mathrm{Sr}$ & -.144 & -.001 & -.801 & -.064 & .145 & .173 & .863 & .074 \\
\hline V & .701 & .515 & .225 & .171 & .923 & -.063 & -.032 & .115 \\
\hline $\mathrm{Zn}$ & -.424 & .142 & .498 & -.409 & .116 & .016 & .048 & .882 \\
\hline
\end{tabular}


Appendix Table 8.--Comparison of factor interpretations, A) 20X20 log-ratio R-matrix, B) 20X20 raw R-matrix, and C) 35X35 R-matrix used in original principal components analysis, Salmon River Mountains data set.

A--20X20 log-ratio R-matrix

Factor 1--Micas and chlorite $\left(\mathrm{MgO}, \mathrm{K}_{2} \mathrm{O}, \mathrm{TiO}_{2}, \mathrm{Cr}, \mathrm{Ni}, \mathrm{Sc}\right.$, and $\left.\mathrm{V}\right)$ vs $\mathrm{Cu}$ and $\mathrm{Pb}$--grain size.

Factor 2--Rare earth minerals (Ce, $\mathrm{La}$, and $\mathrm{Nd}$ vs $\mathrm{Cr}$ and $\mathrm{V})$ - provenance or metamorphism.

Factor 3--Plagioclase $\left(\mathrm{CaO}, \mathrm{Na}_{2} \mathrm{O}\right.$, and $\mathrm{Sr}$ vs $\mathrm{Fe}_{\mathrm{T}} \mathrm{O}_{3}$ and $\left.\mathrm{Zn}\right)$ - provenance.

Factor 4--Potassium silicates $\left(\mathrm{SiO}_{2}, \mathrm{Al}_{2} \mathrm{O}_{3}\right.$, and $\mathrm{K}_{2} \mathrm{O}$ vs $\left.\mathrm{CaO}\right)$--provenance or grain size.

B--20X20 raw R-matrix

Factor 1--Micas and chlorite $\left(\mathrm{Al}_{2} \mathrm{O}_{3}, \mathrm{MgO}, \mathrm{K}_{2} \mathrm{O}, \mathrm{TiO}_{2}, \mathrm{Cr}, \mathrm{Ni}, \mathrm{Sc}\right.$, and V) vs $\mathrm{SiO}_{2}$--grain size.

Factor 2--Rare earth minerals ( $\mathrm{Ce}, \mathrm{La}$, and $\mathrm{Nd}$ )-provenance or metamorphism.

Factor 3--Plagioclase $\left(\mathrm{CaO}, \mathrm{Na}_{2} \mathrm{O}\right.$, and $\left.\mathrm{Sr}\right)$ - provenance.

Factor 4--Base metal minerals ( $\mathrm{Pb}$ and $\mathrm{Zn}$ )--mineralization.

C--35X35 original R-matrix

Factor 1--Micas and chlorite $\left(\mathrm{Al}_{2} \mathrm{O}_{3}, \log \mathrm{MgO}, \mathrm{K}_{2} \mathrm{O}, \mathrm{TiO}_{2}, \mathrm{LOI}, \mathrm{Be}, \log \mathrm{Cr}, \log \mathrm{Ga}, \log \mathrm{Li}, \mathrm{Ni}, \mathrm{Sc}, \log \mathrm{Th}, \mathrm{U}\right.$, and V) vs $\mathrm{SiO}_{2}$--grain size.

Factor 2--Rare earth minerals $(\log \mathrm{Ce}, \mathrm{La}, \mathrm{Nd}, \log \mathrm{Y})$ - provenance or metamorphism.

Factor 3--Base metal minerals ( $\log \mathrm{Co}, \log \mathrm{Mn}, \log \mathrm{Pb}, \log \mathrm{Zn}$ )--mineralization.

Factor 4--Plagioclase $\left(\log \mathrm{CaO}, \mathrm{Na}_{2} \mathrm{O}, \log \mathrm{Sr}, \log \mathrm{Y}, \log \mathrm{Yb}\right)-$-provenance.

Appendix Table 9--Correlations of row geometric means (GM) with raw compositional data, Salmon River Mountains data set. $\mathrm{Fe}_{\mathrm{T}} \mathrm{O}_{3}$, total iron as $\mathrm{Fe}_{2} \mathrm{O}_{3}$.

\begin{tabular}{lc}
\hline $\begin{array}{l}\text { Oxide or } \\
\text { element }\end{array}$ & Row GM \\
\hline $\mathrm{SiO}_{2}$ & -.552 \\
$\mathrm{Al}_{2} \mathrm{O}_{3}$ & .441 \\
$\mathrm{Fe}_{\mathrm{T}} \mathrm{O}_{3}$ & .245 \\
$\mathrm{MgO}$ & .470 \\
$\mathrm{CaO}$ & .529 \\
$\mathrm{Na} \mathrm{O}_{2} \mathrm{O}$ & .288 \\
$\mathrm{~K}_{2} \mathrm{O}$ & -.004 \\
$\mathrm{TiO}_{2}$ & .626 \\
$\mathrm{Ce}$ & .471 \\
$\mathrm{Co}$ & .431 \\
$\mathrm{Cr}$ & .579 \\
$\mathrm{Cu}$ & .357 \\
$\mathrm{La}$ & .567 \\
$\mathrm{Nd}$ & .539 \\
$\mathrm{Ni}$ & .711 \\
$\mathrm{~Pb}$ & .226 \\
$\mathrm{Sc}$ & .555 \\
$\mathrm{Sr}$ & .525 \\
$\mathrm{~V}$ & .543 \\
$\mathrm{Zn}$ & .518 \\
\hline
\end{tabular}

